\title{
Taxonomic revision of West African cone snails (Gastropoda: Conidae) based upon mitogenomic studies: implications for conservation
}

\author{
Manuel J. TENORIO ${ }^{1, *}$, Samuel ABALDE ${ }^{2}$, José R. PARDOS-BLAS ${ }^{3} \&$ Rafael ZARDOYA $^{4}$ \\ ${ }^{1}$ Departamento CMIM y Química Inorgánica - Instituto de Biomoléculas (INBIO), Facultad de \\ Ciencias, Torre Norte, $1^{\text {a }}$ Planta, Universidad de Cadiz, 11510 Puerto Real, Cadiz, Spain. \\ ${ }^{2,3,4}$ Museo Nacional de Ciencias Naturales (MNCN-CSIC), José Gutiérrez Abascal 2, \\ 28006 Madrid, Spain. \\ *Corresponding author: manuel.tenorio@uca.es \\ ${ }^{2}$ Email: saabalde@gmail.com \\ ${ }^{3}$ Email: joserrapblas@gmail.com \\ ${ }^{4}$ Email: rafaz@mncn.csic.es \\ ${ }^{1}$ urn:Isid:zoobank.org:author:24B3DC9A-3E34-4165-A450-A8E86B0D1231 \\ ${ }^{2}$ urn:lsid:zoobank.org:author:C72D4F45-19A1-4554-9504-42D1705C85A3 \\ ${ }^{3}$ urn:lsid:zoobank.org:author:1CAB2718-4C97-47EE-8239-0582C472C40E \\ ${ }^{4}$ urn:Isid:zoobank.org:author:C55129E8-7FF7-41B2-A77C-4097E61DDD2E
}

\begin{abstract}
In the last few years, a sharp increase in the number of descriptions of new species of West African cone snails, particularly from the Cabo Verde Archipelago, has taken place. In previous studies, we used mitogenome sequences for reconstructing robust phylogenies, which comprised in total 120 individuals representing the majority of species $(69.7 \%)$ described from this biogeographical region (except Angolan endemics) and grouped into seven genera within the family Conidae. Here, we add another 12 individuals representing endemic species that were missing in the previous studies. We use the phylogenies to identify monophyletic groups and a genetic divergence threshold $(0.2 \%$ uncorrected $p$ distance) to determine the number of valid species. As a result, the number of valid West African cone species could be drastically reduced to at least $40 \%$, indicating that some recent poor-quality descriptions loosely based on phenotypic characters prone to convergence such as the shape and color patterns of the shell have contributed substantially to taxonomic inflation. Several previously accepted species with a reduced geographical distribution now become phenotypic forms of the remaining valid species, which increase their distribution ranges. In contrast, several cryptic species are now uncovered and described. For instance, Africonus insulae sp. nov. and Kalloconus canariensis sp. nov. are hereby introduced as new species. A detailed systematic account with illustrations and relevant information is presented. Lectotypes are designated for Conus trochulus and Conus irregularis, and neotypes for Conus crotchii and Conus diminutus. According to our results, it is strongly recommended that any future introduction of new taxa names for cone snails from West Africa should be supported by molecular and/ or anatomical rather than exclusively shell morphological data. The taxonomic decisions here taken have direct implications for conservation and will eventually require re-evaluation of the Red List risk status of an important number of species.
\end{abstract}


Keywords. Mitochondrial genome, phylogeny, Conidae, West Africa, conservation.

Tenorio M.J., Abalde S., Pardos-Blas J.R. \& Zardoya R. 2020. Taxonomic revision of West African cone snails (Gastropoda: Conidae) based upon mitogenomic studies: implications for conservation. European Journal of Taxonomy 663: 1-89. https://doi.org/10.5852/ejt.2020.663

\section{Introduction}

The more than 900 described species of cone snails (Caenogastropoda, Conidae; WoRMS, accessed March 2020) are widely found in all tropical and subtropical seas from intertidal zones to deep waters. For a long time, studies on biodiversity of cone snails have mostly been focused on species from the IndoWest Pacific region (e.g., Röckel et al. 1995; Duda et al. 2001) to the detriment of others such as West Africa (e.g., Monteiro et al. 2004; Cunha et al. 2005; Duda \& Rolan 2005). This region extends from Angola along the African coast to Morocco, including the Cabo Verde and the Canary Islands, among other archipelagos. The few endemic cone species found south of Angola, inhabiting the area comprised between Namibia and the Cabo Agulhas, are considered members of the South African malacological province (Tenorio et al. 2008). While several works partially treated the description of the cone snail fauna from independent geographical areas in West Africa (Senegal: Pin \& Leung Tack 1995; Cabo Verde: Rolán 1980, 1990; Angola: Rolán \& Röckel 2000; Saint Helena: Tenorio et al. 2016), the first comprehensive review of the cone snail fauna from West Africa and the Mediterranean was published by Monteiro et al. (2004). That work covered and illustrated 99 species, subspecies and forms of cone snails from the Mediterranean Sea, the Atlantic coast of southern Spain and Portugal, the coast of Africa from Morocco to south Angola, and the archipelagos of Canaries, Cabo Verde and São Tomé e Príncipe, as well as the island of Saint Helena. Since 2004, the number of new species names introduced in the literature for West African cone snails has risen to the spectacular number of 178 as of December 2019 (Fig. 1). However, many of these new species names were introduced in non-peer reviewed amateur

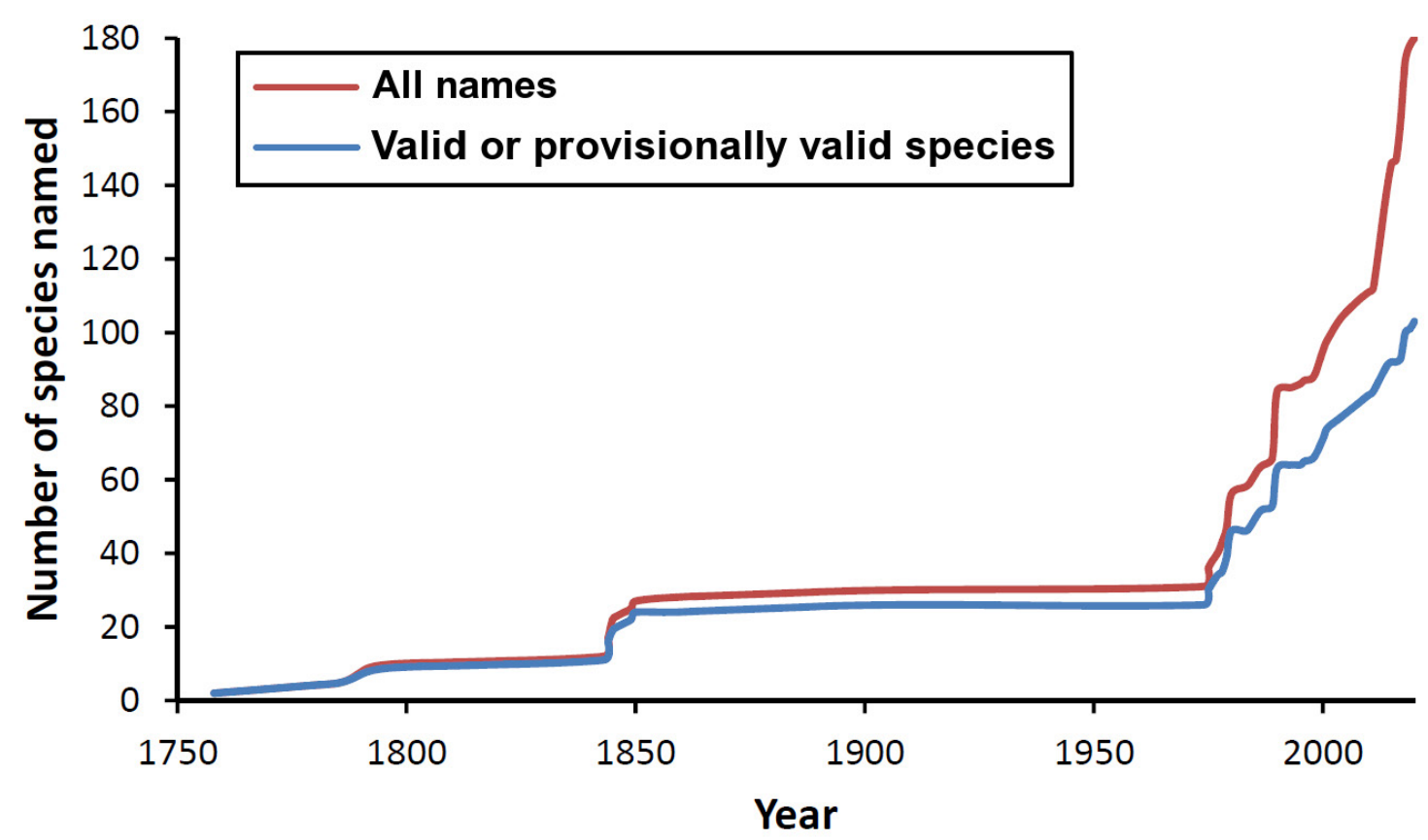

Fig. 1. Cumulative number of described (red) and valid or provisionally valid (blue) West African cone species per year after revision. 
magazines (Cossignani 2014; Cossignani \& Fiadeiro 2014a, 2014b, 2015a, 2015b, 2015c, 2017a, 2017b, 2017c, 2018a, 2018b, 2018c, 2019a, 2019b) based on rather poor-quality descriptions of shell characters only, neither with specific references to intraspecific variability nor with statistical analyses of shell morphometry. Only in a few cases, the new taxa described were supported by molecular analyses (Tenorio et al. 2014, 2017, 2018).

Studies focused on West African cones have revealed high levels of endemicity and peaks of species diversity concentrated in subtropical areas around Senegal and Angola on the continent, and most prominently in the Cabo Verde Archipelago, which was estimated to harbor about $10 \%$ of cone species diversity worldwide (Cunha et al. 2005, 2014). Several species endemic to the Cabo Verde Archipelago were described by Hwass, Reeve, Kiener and G.B. Sowerby II in the $18^{\text {th }}$ and $19^{\text {th }}$ centuries. However, in the original descriptions, the type localities were erroneous (i.e., "America"), too vague ("West Africa"), or simply not stated. Modern studies on the cones of the Cabo Verde Archipelago began with the description of the taxon Africonus anthonyi Petuch, 1975a, and with the works of Burnay \& Monteiro (1977) and Röckel et al. (1980a). These pioneering works were followed by the descriptions of multiple new taxa by Trovão $(1978,1979)$, and most notably by Rolán and co-workers (see Rolán 1990 and references therein), who extensively sampled the archipelago in the 1980's. The first molecular work on cones from Cabo Verde dates back to the first decade of this century and reconstructed their phylogeny based on partial mitochondrial and nuclear gene sequences (Cunha et al. 2005; Duda \& Rolán 2005).

In 2011, a workshop for the International Union for the Conservation of Nature (IUCN) Red List of Threatened Species held in Chicago assessed threats to over 630 species of cone snails (Peters et al. 2013, 2016). The results of this assessment indicated that three-quarters of the species evaluated were not considered at risk of extinction. However, in the West African region, $41.8 \%$ of the 98 cone snail species evaluated from this area were classified as threatened or near threatened with extinction, mostly due to their restricted distributions often in habitats under high human pressure. In subsequent years, the very sharp increase in the number of descriptions of new species of West African cone snails, particularly from the Cabo Verde Archipelago, complicates monitoring programs as well as future evaluations and eventual updates of their risk status. Furthermore, the number of endemic gastropod mollusks in the Cabo Verde Archipelago (of which cone snails constitute the main component) has been one of the factors recently used to support the exclusion of Cabo Verde from the remaining Macaronesian archipelagos and the claim for its own biogeographic subprovince within the West African Transition province (Freitas et al. 2019). Therefore, if the number of valid endemic species of cone snails in the Cabo Verde Archipelago is modified significantly, the new figures would have an impact on the results of this study and its conclusions would accordingly require a re-evaluation in the light of more accurate data. It also may affect various downstream analyses such as, e.g., the estimation of speciation rates (Phuong et al. 2019).

Mitochondrial genomes or mitogenomes have proven to be particularly useful for disentangling phylogenetic relationships within gastropods at different taxonomic levels (Grande et al. 2008; Osca et al. 2015; Uribe et al. 2017). In the last few years, we have carried out a comprehensive survey of cone snails from the Cabo Verde Archipelago, Senegal, the Canary Islands and the Mediterranean region. Up to 120 mitogenomes covering 89 species (for some species more than one individual was sequenced to distinguish intra- and interspecific divergences) and seven genera (Africonus Petuch, 1975a, Lautoconus Monterosato, 1923, Kalloconus da Motta, 1991, Trovaoconus Tucker \& Tenorio, 2009, Chelyconus Mörch, 1852, Genuanoconus Tucker \& Tenorio, 2009 and Monteiroconus da Motta, 1991) were sequenced (Cunha et al. 2009; Abalde et al. 2017a, 2017b, 2019; Uribe et al. 2017). We used these mitogenomes to reconstruct robust phylogenies in order to identify monophyletic groups and resolve the relationships among taxa and populations. Moreover, we used a genetic divergence threshold 
(see Material and methods) to determine the number of valid species of West African cones (Abalde et al. 2017a, 2017b).

Here, we reconstruct a new phylogeny based on 54 mitogenomes representing valid species as deduced from previous studies (Abalde et al. 2017a, 2017b) as well as new mitogenomes of 10 species endemic to Senegal, Gambia, Canary Islands and Cabo Verde not previously sampled, and two species endemic to Angola, another important hotspot of endemism for cone snails along the West African coast. The total number of recorded species in West Africa (without Angola) is 145 and we include 101 species in the phylogenies of Abalde et al. (2017a, 2017b) plus this work (i.e., 69.7\%). In this monograph, we discuss in detail the taxonomic implications of the reconstructed phylogenies for West African cones taking into account the $0.2 \%$ divergence threshold. The number of valid West African cone species is drastically reduced into almost one half. This implies a modification of the distribution ranges for many of the remaining valid endemic species, thus directly affecting in many cases their Red List risk status, which will eventually require re-evaluation for proper downgrade or upgrade of their respective risk classifications.

The systematic account herein presented covers in detail all valid cone species from West Africa excluding those endemic to Angola. The mitogenomes of cone specimens from this latter area are now being systematically sequenced, and the results will be reported elsewhere in due course. We have taken some necessary taxonomic actions affecting the status of certain taxa names and type material. The phylogenetic analysis here performed has also revealed two previously undescribed new taxa, namely Africonus insulae sp. nov. from Santa Luzia Island, Cabo Verde, and Kalloconus canariensis sp. nov. from the Canary Islands. These two new species are formally described herein.

\section{Material and methods}

Most of the material studied here was previously deposited in institutional repositories (MNCN and others; see Abbreviations below). Descriptions and measurements are based on shells oriented in the traditional way: spire up with the aperture facing the viewer. The taxonomy used in the present work follows Tucker \& Tenorio (2013), who recognize up to 91 genera within the family Conidae. Instead, other authors have proposed only 4-6 genera within the family Conidae (Puillandre et al. 2015; Uribe et al., 2017), with the vast majority of species within the genus Conus (a total of 761 members according to WoRMS, accessed March 2020). The clades indicated in the phylogeny and their association to particular biogeographic units (Africonus to Cabo Verde; Varioconus to continental coast of Africa; Lautoconus to the Mediterranean Sea) lead us, however, to use generic names given the high level of sequence divergence observed. Furthermore, compared to other gastropod groups, WoRMS lists, e.g., 27 genera for 620 species in Nassaridae (23 spp. on average per genus), and 52 genera for 261 species in Cypraeidae (5 spp. on average per genus). Considering that Conidae sensu Puillandre et al. (2015) could have 111 genera according to Tucker \& Tenorio (2013), the average number of species per genus would be 9.4, i.e., a number similar to those observed for other gastropod genera. Maps of sampling sites including the names of localities mentioned throughout the text are included as part of the electronic Supplementary Material File 1 for reference, as well as a map showing latitudinal variation in species richness of cone snails along the West African coast and Macaronesian islands reproduced from Cunha et al. (2014) by permission of Oxford University Press.

\section{Morphological analyses}

For the description of new species, we use the following procedure. We describe shell morphology using the terminology established in Röckel et al. (1995). For morphometric comparisons, adult shells selected among available specimens in the collections of the MNCN and other sources (private collections) were measured with a digital caliper, and the measurements rounded to 0.1 millimeter. All the measurements 
are in a spreadsheet, deposited as electronic supporting information (Supplementary Material File 2). For comparison of shell morphometry, we performed analysis of the covariance (ANCOVA) for different shell parameters, namely maximum diameter (MD), height of the maximum diameter (HMD) and spire height $(\mathrm{SH})$, using species hypotheses as factor and shell length $\left(\mathrm{S}_{\mathrm{L}}\right)$ as covariate. Additionally, we compared the mean values of $S_{L}$ statistically using t- and U-tests. Statistical tests were carried out using STATGRAPHICS XVII-X64, after all the measurement sets passed the normality tests. We use the terminology for radular morphology of Tucker \& Tenorio (2009), and the abbreviations in Kohn et al. (1999) and Rolán \& Raybaudi-Massilia (2002). The radular sac was dissected from the cone snail and soft parts were digested in concentrated aqueous potassium hydroxide for 24 hours. The resulting mixture was then placed in a Petri dish and examined with a binocular microscope. The radular teeth were removed with fine tweezers, rinsed with distilled water, then mounted on a slide using Aquatex (Merck) Mounting Medium, and examined under a compound microscope. Figure photos were obtained with a CCD camera attached to the microscope.

\section{Molecular and phylogenetic analyses}

Most of the samples, mitogenome (mt) sequences and phylogenetic analyses involved in this taxonomic revision have originally been reported in previous papers (Cunha et al. 2009; Abalde et al. 2017a, 2017b, 2019; Uribe et al. 2017). Here, we sequenced additional mitogenomes from the species listed in Table 1, which also provides information on localities, vouchers, genome sizes, and GenBank accession numbers (see a full list of previous and current mitogenomes in the electronic Supplementary Material File 3). All laboratory procedures and sequence analyses involving the new mitogenomes were performed as in Abalde et al. (2017a) except if otherwise mentioned. For Africonus curralensis (Rolán, 1986), Kalloconus pseudonivifer (Monteiro, Tenorio \& Poppe, 2004), Kalloconus canariensis sp. nov. and Varioconus echinophilus (Petuch, 1975b), long PCRs and Illumina sequencing were performed (Abalde et al. 2017a). However, the samples of Varioconus equiminaensis (Schönherr, 2018), V. fernandi (Petuch \& Berschauer, 2018), V. gambiensis (Petuch \& Berschauer, 2018), V. pineaui (Pin \& Leung Tack, 1989b), V. rikae (Petuch \& Berschauer, 2018), V. trovaoi (Rolán \& Röckel, 2000), V. trencarti (Nolf \& Verstraeten, 2008) and $V$. wolof (Petuch \& Berschauer, 2018) rendered DNA of poor quality and long PCRs did not work. Therefore, we used universal coxl LCO1490+HCO2198 (Folmer et al. 1994) and rrnL 16SAR-L+16SBRH primers (Palumbi et al. 1991), and designed up to 23 pairs of specific primers (see Supplementary Material File 4) to amplify through standard PCRs overlapping fragments of 500-1000 bp covering the entire mitogenome except the control region. Standard PCR conditions were as in Abalde et al. (2017a), and annealing temperatures for each pair of primers were $48^{\circ} \mathrm{C}$ except for the pair ANGND1-F/R, which was $52^{\circ} \mathrm{C}$. Amplified fragments were sequenced using the Sanger method using the PCR primers at Macrogen (Seoul, Korea). Illumina sequences were assembled as in Abalde et al. (2017a) whereas Sanger sequences were assembled manually using Geneious ${ }^{\circledR}$ 8.0.3. Once annotated, all mt protein-coding and rRNA gene nucleotide sequences were aligned and concatenated. The selected bestfit partitions according to the Bayesian Information Criterion (BIC) included the three codon positions in the case of protein-coding genes plus the two rRNA genes combined. PartitionFinder2 (Lanfear et al. 2017) was used to select best-fit model for each partition according to the BIC (GTR $+\mathrm{I}+\mathrm{G}$ for each codon position; $\mathrm{HKY} 85+\mathrm{I}+\mathrm{G}$ for the rRNA genes) and a maximum likelihood (ML) tree was reconstructed (see Supplementary Material File 5) using IQtree 1.6.10 (Nguyen et al. 2015; Chernomor et al. 2016) in the CIPRES gateway (Miller et al. 2010). Statistical support was measured with 10000 ultrafast bootstrap pseudoreplications (-bb). The recovered topology was used as constraint for performing a Bayesian estimation of divergence times using a relaxed molecular clock calibrated as in (Abalde et al. 2017a). Two nodes with low support, A. longilineus, A. regonae, A. felitae $(\mathrm{bb}=76)$ and $V$. trecarti, $V$. unifasciatus, $V$ guanche $(\mathrm{bb}=66)$ were not constrained during topology fixation. 


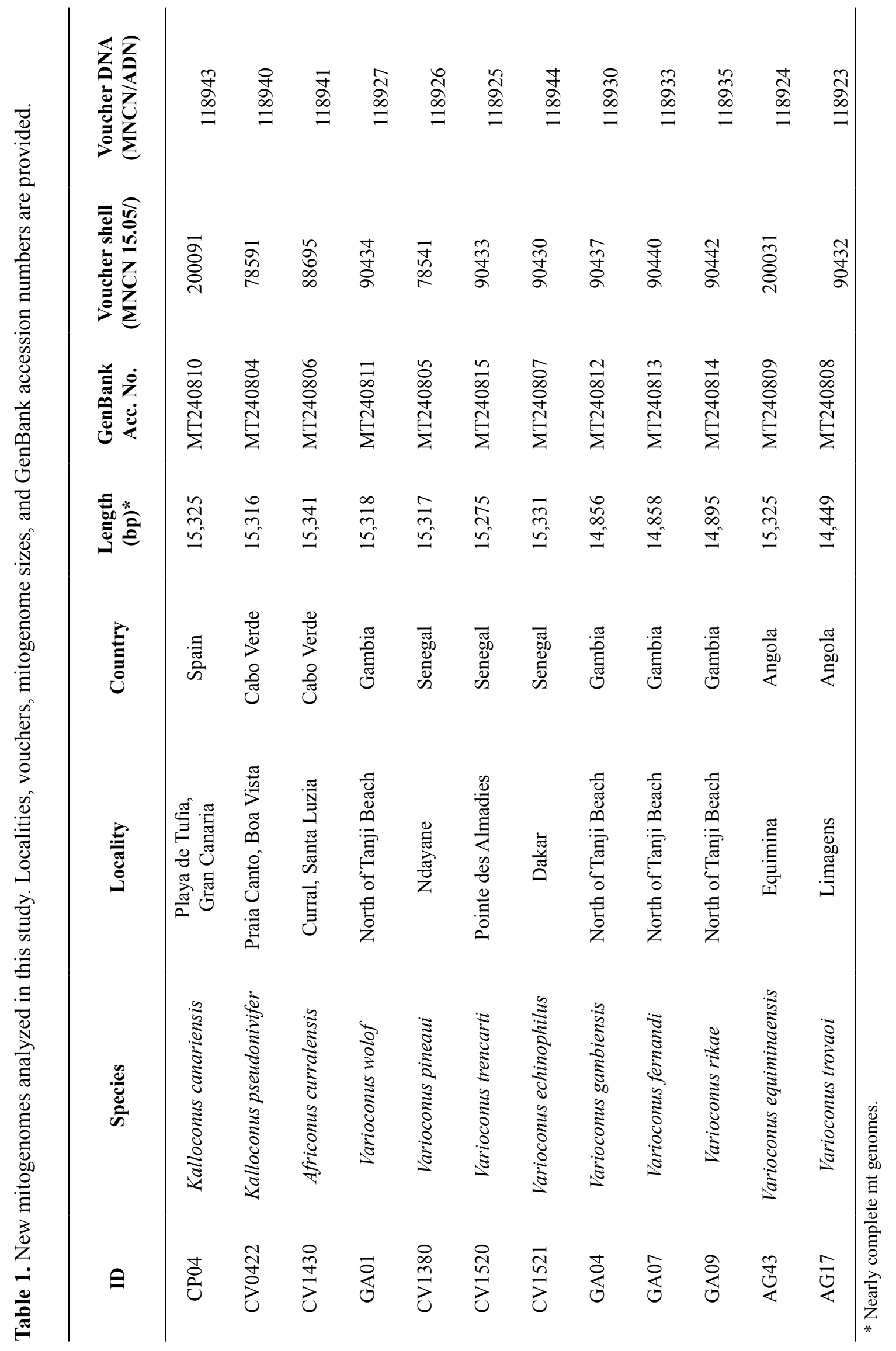




\section{Species delimitation}

The remarkable diversification of cone snails in West Africa has occurred through radiation events concentrated in geographically restricted hotspots. As a result, species delimitation within the group is challenging as morphological differences in many cases are subtle, and genetic divergences are low. Following Abalde et al. (2017a, 2017b), we use the reconstructed phylogeny (that delimits monophyletic groups) and pairwise uncorrected $p$ distances estimated among the mitogenome sequences with a threshold of $0.2 \%$ as primary criteria for species separation. This threshold was set in (Abalde et al. 2017a) based on divergences within two clades in the phylogeny: (1) Africonus verdensis and its sister species Africonus raulsilvai + Africonus gonsaloi; (2) Varioconus guanche and its sister species Varioconus unifasciatus. We assumed that $A$. verdensis living off Santiago Island in Cabo Verde only and $V$. guanche, from the Canary Islands, and far away from Senegal cones, are both valid species, and thus their sequence divergence to the corresponding sister group species could be used as minimum threshold. Actually, this was a rather conservative criterion when compared with literature. Our threshold is equivalent to a $0.5 \%$ Kimura 2-parameter (K2P) distance for the barcoding coxl fragment in our dataset, and thus it is significantly lower than the reported mean intraspecific $\mathrm{K} 2 \mathrm{P}$ distance of $0.8 \%$ for various gastropods (Borges et al. 2016). In those few cases in which the mitogenome was not available, we take a conservative approach. Those species having distinctive morphological and biogeographical features are given the consideration of provisionally valid. This status is assigned to cone snail species from westernmost islands of Cabo Verde (as those for which a mitogenome is available show important sequence divergence); to the cone endemics at Brava and São Nicolau islands; and to most cone snails endemic to Angola, which are currently under study. For recently described species showing only subtle differences in shell pattern or apparent differences in shell morphometry not statistically tested in the original descriptions, we propose to synonymize the name of the taxon under consideration with that of the morphologically closest species with known mitogenome (specific arguments for each case are provided and discussed in the systematic account below). A complete alphabetic list of names, synonyms (with sources for synonymy) and other relevant data is included in the Supplementary Material File 3.

\begin{tabular}{|c|c|}
\hline \multicolumn{2}{|c|}{ Abbreviations of museums and institutions } \\
\hline CAS & $=$ California Academy of Sciences, San Francisco, USA \\
\hline CSIC & $=$ Consejo Superior de Investigaciones Científicas, Spain \\
\hline DMNH & $=$ Delaware Museum of Natural History, Wilmington, USA \\
\hline LSL & $=$ Linnean Society of London, London, UK \\
\hline MHNG & $=$ Muséum d'Histoire Naturelle, Geneva, Switzerland \\
\hline MJT & $=$ Manuel J. Tenorio reference collection, Jerez, Spain \\
\hline MMM & $=$ Malacologia Mostra Mondiale, Cupra Marittima, Italy \\
\hline MNCN & $=$ Museo Nacional de Ciencias Naturales, Madrid, Spain \\
\hline MNHN & $=$ Muséum national d'histoire naturelle, Paris, France \\
\hline NBC & $=$ Naturalis Biodiversity Centre, Leiden, The Netherlands \\
\hline NHMUK & $=$ Natural History Museum, London, UK \\
\hline NHMW & $=$ Naturhistorisches Museum, Vienna, Austria \\
\hline NMSF & $=$ Natur-Museum Senckenberg, Frankfurt, Germany \\
\hline SMNS & $=$ Staatliches Museum für Naturkunde Stuttgart am Löwentor, Stuttgart, Germany \\
\hline $\mathrm{UCV}$ & $=$ Reference collection of the Universidade de Cabo Verde, Mindelo, Cabo Verde \\
\hline ZMA & $=$ Zoological Museum, Amsterdam (collection now in NBC), The Netherlands \\
\hline ZMUC & $=$ Zoological Museum, University of Copenhagen, Denmark \\
\hline
\end{tabular}




\section{Results}

\section{Phylogeny and time tree of West African cones based on mitogenomes}

The almost complete mitogenomes (except the control region) of Africonus curralensis, a new specimen of Kalloconus pseudonivifer, Kalloconus canariensis sp. nov., Varioconus echinophilus, $V$. equiminaensis, $V$. fernandi, $V$. gambiensis, $V$. pineaui, $V$. rikae, $V$. trovaoi, $V$. trencarti and $V$. wolof were sequenced. The following primer pairs did not work in few species: ANG-ND4-F/R in Varioconus gambiensis and Varioconus fernandi; ANG-ND1-F/R in Varioconus trovaoi; universal 16SAR-L/SBR-H in Varioconus rikae. A highly resolved (most nodes show maximal statistical support) phylogenetic tree of West African cones is reconstructed based on mitogenomes and using Monteiroconus tabidus (Reeve, 1844), Genuanoconus genuanus (Linnaeus, 1758) and Chelyconus ermineus (Born, 1778) as outgroup taxa (see Supplementary Material File 5). The recovered topology was used as constraint to reconstruct a chronogram (Fig. 2) under a relaxed molecular clock calibrated with fossils as in Abalde et al. (2017a). The first split in the ingroup separated specimens within genus

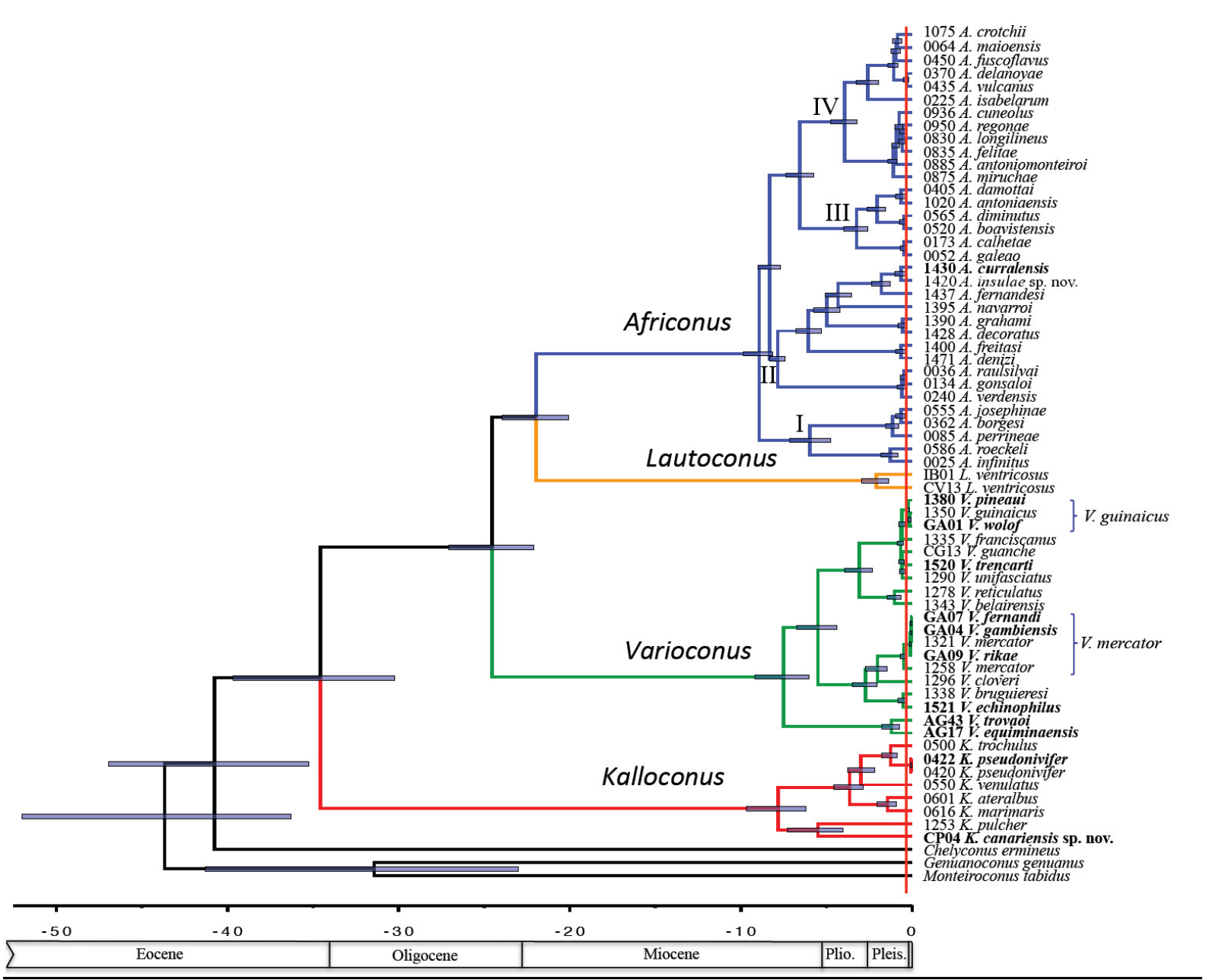

Fig. 2. Phylogenetic relationships of West African cones and species delimitation. A time tree (relaxed molecular clock) was reconstructed following methods and calibrations in Abalde et al. (2017a). Dates are in million years. Bold names indicate new mitogenomes. A red line indicates the threshold (uncorrected $\mathrm{p}$ distance of $0.2 \%$, based on the divergences between Africonus verdensis (Trovão, 1979) and its sister group and Varioconus guanche (Lauer, 1993) and its sister group) for species delimitation. 
Kalloconus from the remaining analyzed cones. Within Kalloconus, two main clades were recovered. One corresponded to the continental Kalloconus pulcher ([Lightfoot, 1786]) and one pulcher-like individual from Gran Canaria, Canary Islands, whereas the other included all species of Kalloconus endemic to Cabo Verde: K. marimaris Tenorio, Abalde \& Zardoya, 2018 was sister to K. ateralbus (Kiener, 1850) and both were sister to a clade including K. venulatus (Hwass in Bruguiére, 1792) sister to K. pseudonivifer + K. trochulus (Reeve, 1844) (Fig. 2). Note that Kalloconus atlanticoselvagem (Afonso \& Tenorio, 2004) and most K. pseudonivifer (except those from Praia Canto in Boa Vista; a second specimen from this locality was sequenced to confirm previous results in Abalde et al. 2017a) did not show enough divergence to K. trochulus, and had to be synonymized with this latter species (see Abalde et al. 2017a). On the other hand, the pulcher-like specimen from the Canary Islands showed a large sequence divergence from mainland Kalloconus pulcher indicating that they were not conspecific (Fig. 2). Consequently, we have introduced the new taxon name Kalloconus canariensis sp. nov. for the pulcher-like individuals from the Canary Islands, which must be considered representatives of a full species sister to K. pulcher.

The remaining analyzed cones were recovered in three main clades (Fig. 2). A first clade corresponded to the genus Varioconus da Motta, 1991 (type species Varioconus variegatus (Kiener, 1848)) and included two monophyletic groups, one grouping cones endemic to Senegal and V. guanche (Lauer, 1993a) comb. nov. from the Canary Islands and the other including cones endemic to Angola (cox 1 sequences indicate that the taxon $V$. jourdani (da Motta, 1984), endemic to Saint Helena Island, also appeared deeply nested within the clade of endemic cones from Angola; see Tenorio et al. 2016). Three main lineages were retrieved within Varioconus endemic to Senegal and Canary Islands. Most phylogenetic relationships within these three lineages were reported in Abalde et al. (2017b). Here, we only focus on those involving the newly sequenced mitogenomes. The species Varioconus pineaui and $V$. wolof have to be synonymized with $V$. guinaicus (Fig. 2). The species Varioconus fernandi, $V$. gambiensis and $V$. rikae have to be synonymized with $V$. mercator. The species Varioconus trencarti remains valid and is sister to V. unifasciatus (Fig. 2). The species Varioconus echinophilus is valid and sister to V. bruguieresi (Fig. 2). Note that the cones endemic to Senegal and the species from Canary Islands were previously assigned to the genus Lautoconus which resulted a polyphyletic group in the reconstructed tree (Tucker \& Tenorio 2009). To resolve this problem, the clade could receive a new genus name but the low sequence divergences to the sister group did not justify such taxonomic action, and instead supported ascription of these species to the genus Varioconus as the most senior supraspecific taxon name (Fig. 2). Therefore, the genus Lautoconus was restricted to Lautoconus ventricosus (Gmelin, 1791) from the Mediterranean Sea and the adjacent Atlantic Ocean region. This species was recovered as sister to cones endemic to Cabo Verde belonging to the genus Africonus Petuch, 1975a (Fig. 2). Note that the two mitogenomes of Lautoconus ventricosus from Faro (Portugal) and Formentera Island (Spain) show an important sequence divergence that might suggest a potential case of a cryptic species complex and could merit further study with an extended taxon sampling.

The genus Africonus was divided into four main clades (I to IV), each having two main lineages. Most phylogenetic relationships within Africonus were reported in Abalde et al. (2017a). Here, we only focus on those involving the newly sequenced mitogenome. Within lineage II, the specimen from a population in Santa Luzia shows enough sequence divergence to the sister group, Africonus curralensis (Rolán, 1986), and, thus, is ascribed to a new species, namely Africonus insulae sp. nov. 


\section{Systematic account}

Family Conidae Fleming, 1822

Genus Africonus Petuch, 1975a

Africonus antoniaensis Cossignani \& Fiadeiro, 2014

Fig. 3A

Africonus antoniaensis Cossignani \& Fiadeiro, 2014a: 16.

Africonus padarosae Cossignani \& Fiadeiro, 2018a: 18. syn. nov.

\section{Material examined}

\section{Holotype}

CABO VERDE $• 15.6 \mathrm{~mm}$; Boa Vista Island, Baía Antónia; 0.5 to $5 \mathrm{~m}$ depth on rocky bottom; MMM.

\section{Other material}

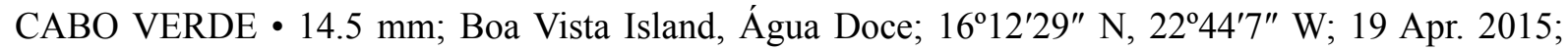
MNCN exped.; GenBank mitochondrion, partial genome: MF491587; MNCN 15.05/79889 (Fig. 3A) • 13.4 mm, holotype of Africonus padarosae; Boa Vista Island, Baixa de Padaroso; MMM.

\section{Geographical distribution}

North of Boa Vista Island, Cabo Verde Archipelago, from Ponta do Sol towards the east, including Derrubado area.

\section{Conservation status in IUCN Red List}

Not evaluated.

\section{Remarks}

The specimen sequenced from this recently described taxon appears closely related to $A$. damottai, but at a genetic distance consistent with its consideration as a valid species. The shell of the recently described A. padarosae is morphologically very close to that of $A$. antoniaensis, and separation at the species level is unsupported, as it falls within the morphological variability of the latter. As it happens with many other recently named cone snails endemic to the Cabo Verde Archipelago, the species separation criterion was based mainly on the type locality, and on subtle conchological differences, which were never statistically tested. In this particular case, the authors claimed that the A. padarosae could be separated from $A$. antoniaensis based upon "different spire profile and more elongated shape" without any statistically supported morphometric analysis. We therefore propose to consider A. padarosae as a mere form of $A$. antoniaensis.

\section{Africonus antoniomonteiroi (Rolán, 1990)}

Fig. 3B

Conus antoniomonteiroi Rolán, 1990: 47, pl. 1, fig. 16.

Conus antoniomonteiroi - Monteiro et al. 2004: 25, pl. 123.

Conus cuneolus form F - Röckel et al. 1980a (not C. cuneolus Reeve, 1843): 107, pl. 3, row 6a, c-f.

\section{Material examined}

\section{Holotype}

CABO VERDE • 16.8 mm; Sal Island, Parda; 0.5 to 1 m depth; E. Rolán leg.; MNCN 15.05/1100 (Fig. 3B). 


\section{Other material}

CABO VERDE - 1 spec.; Sal Island, Pedra Lume; 16 $45^{\prime} 44^{\prime \prime}$ N, 22 $2^{\circ} 3^{\prime} 2^{\prime \prime}$ W; 7 Apr. 2014; MNCN exped.; GenBank mitochondrion, partial genome: MF491578; MNCN 15.05/79794.

\section{Geographical distribution}

East coast of Sal Island in the Cabo Verde Archipelago, from a point approximately $6 \mathrm{~km}$ north to $8 \mathrm{~km}$ south of the locality of Pedra Lume.

\section{Conservation status in IUCN Red List}

Least concern.

\section{Remarks}

Prior to its introduction as a full species by Rolán (1990), it was referred to as Conus cuneolus form F in Röckel et al. (1980a). In the phylogeny this taxon is certainly a member of the cuneolus clade, but the genetic distances and age divergence estimates are consistent with its consideration as a valid species with habitat restricted to the east coast of Sal Island.

\section{Africonus bellulus (Rolán, 1990)}

Fig. 3C

Conus bellulus Rolán, 1990: 44, pl. 1, fig. 14.

Conus bellulus - Monteiro et al. 2004: 28, pl. 85.

\section{Material examined}

\section{Holotype}

CABO VERDE • 18.9 mm; Santa Luzia Island, Curral; E. Rolán leg.; MNCN 15.05/1098 (Fig. 3C).

Paratype

CABO VERDE • 1 spec.; Santa Luzia Island, Curral; E. Rolán leg.; MJT.

\section{Geographical distribution}

Santa Luzia (Curral) and São Vicente (Saragaça), Cabo Verde Archipelago.

\section{Conservation status in IUCN Red List}

Data deficient.

\section{Remarks}

No specimens of this species have been molecularly examined. Very few specimens have surfaced in the last 30 years, and most of them have been collected as empty shells. Clearly, more studies are needed in order to confirm the status of this taxon. Given the fact that most of the species described from the islands of São Vicente and Santa Luzia have shown relative large genetic divergences, we provisionally consider this as a valid species.

Africonus boavistensis (Rolán \& Fernandes in Rolán, 1990)

Fig. 3D

Conus boavistensis Rolán \& Fernandes in Rolán, 1990: 23, pl. 1, fig. 17.

Africonus barrosensis Cossignani \& Fiadeiro, 2017a: 27. syn. nov. 
Africonus varandinhensis Cossignani \& Fiadeiro, 2017a: 33. syn. nov.

Conus boavistensis - Monteiro et al. 2004: 29, pl. 121.

\section{Material examined}

\section{Holotype}

CABO VERDE • 13.2 mm; Boa Vista Island, Morro de Areia; E. Rolán leg.; MNCN 15.05/1089 (Fig. 3D).

\section{Other material}

CABO VERDE • 1 spec.; Boa Vista Island, Baía do Ervatão; 16²12'3" N, 2254'43" W; 2 Jul. 2013; MNCN exped.; GenBank mitochondrion, partial genome: MF491563; MNCN 15.05/80413 • 1 spec., $11 \mathrm{~mm}$, holotype of Africonus barrosensis; Boa Vista Island, João Barrosa; MMM • $1 \mathrm{spec}, 10.6 \mathrm{~mm}$, holotype of Africonus varandinhensis; Boa Vista Island, Varandinha; MMM.

\section{Geographical distribution}

Multiple localities around Boa Vista Island, Cabo Verde Archipelago.

\section{Conservation status in IUCN Red List}

Least concern.

\section{Remarks}

This small species is widely distributed around the island of Boa Vista. It is very variable, and it has given rise to the introduction of several names (applied to representative specimens from certain local populations from the southwest and south coasts of the island), which are hereby considered junior synonyms. In the molecular tree, it appears as sister to A. diminutus, with a short genetic distance. Both species belong to a clade in which all the individuals have medium-sized and very broad radular teeth. The specimens in the type series of $A$. barrosensis and A. varandinhensis exhibit shell coloration, pattern and shape consistent with the morphological variability of $A$. boavistensis.

\section{Africonus borgesi (Trovão, 1979)}

Fig. 3E

Conus borgesi Trovão, 1979: 6, pl. 1, fig. 4.

Fig. 3 (opposite page). A. Africonus antoniaensis Cossignani \& Fiadeiro, 2014, $14.5 \mathrm{~mm}$ (MNCN 15.05/79889). B. Conus antoniomonteiroi Rolán, 1990, holotype, $16.8 \mathrm{~mm}$ (MNCN 15.05/1100). C. Conus bellulus Rolán, 1990, holotype, 18.9 mm (MNCN 15.05/1098). D. Conus boavistensis Rolán \& Fernandes in Rolán, 1990, holotype, 13.2 mm (MNCN, 15.05/1089). E. Africonus borgesi (Trovão, 1979), 30.5 mm (MNCN 15.05/88646). F. Conus navarroi calhetae Rolán, 1990, holotype, $26.8 \mathrm{~mm}$ (MNCN 15.05/1096). G. Conus crotchii Reeve, 1849, neotype, 22.5 mm (MNCN 15.05/79971). H. Conus irregularis G.B. Sowerby II, 1858, lectotype, $28.3 \mathrm{~mm}$ (NHMUK 197871/1). I. Africonus cuneolus (Reeve, 1843), 28.2 mm (MNCN, 15.05/79712). J. Conus curralensis Rolán, 1986, holotype, 17 mm (MNCN 15.05/1010). K. Africonus damottai (Trovão, 1979), 18.2 mm (MNCN 15.05/80401). L. Africonus decoratus (Röckel, Rolán \& Monteiro, 1980), $23.1 \mathrm{~mm}$ (MNCN 15.05/78589). M. Africonus delanoyae (Trovão, 1979), $27.6 \mathrm{~mm}$ (MNCN 15.05/80397). N. Africonus denizi Afonso \& Tenorio, 2011, holotype, 11.6 mm (MNCN 15.05/60000). O. Conus diminutus Trovão \& Rolán, 1986, neotype, $14.8 \mathrm{~mm}$ (MNCN 15.05/80416). P. Africonus espingueirensis Cossignani \& Fiadeiro, 2017, holotype, $9.7 \mathrm{~mm}(\mathrm{MMM})$. Scale bars $=10 \mathrm{~mm}$. 


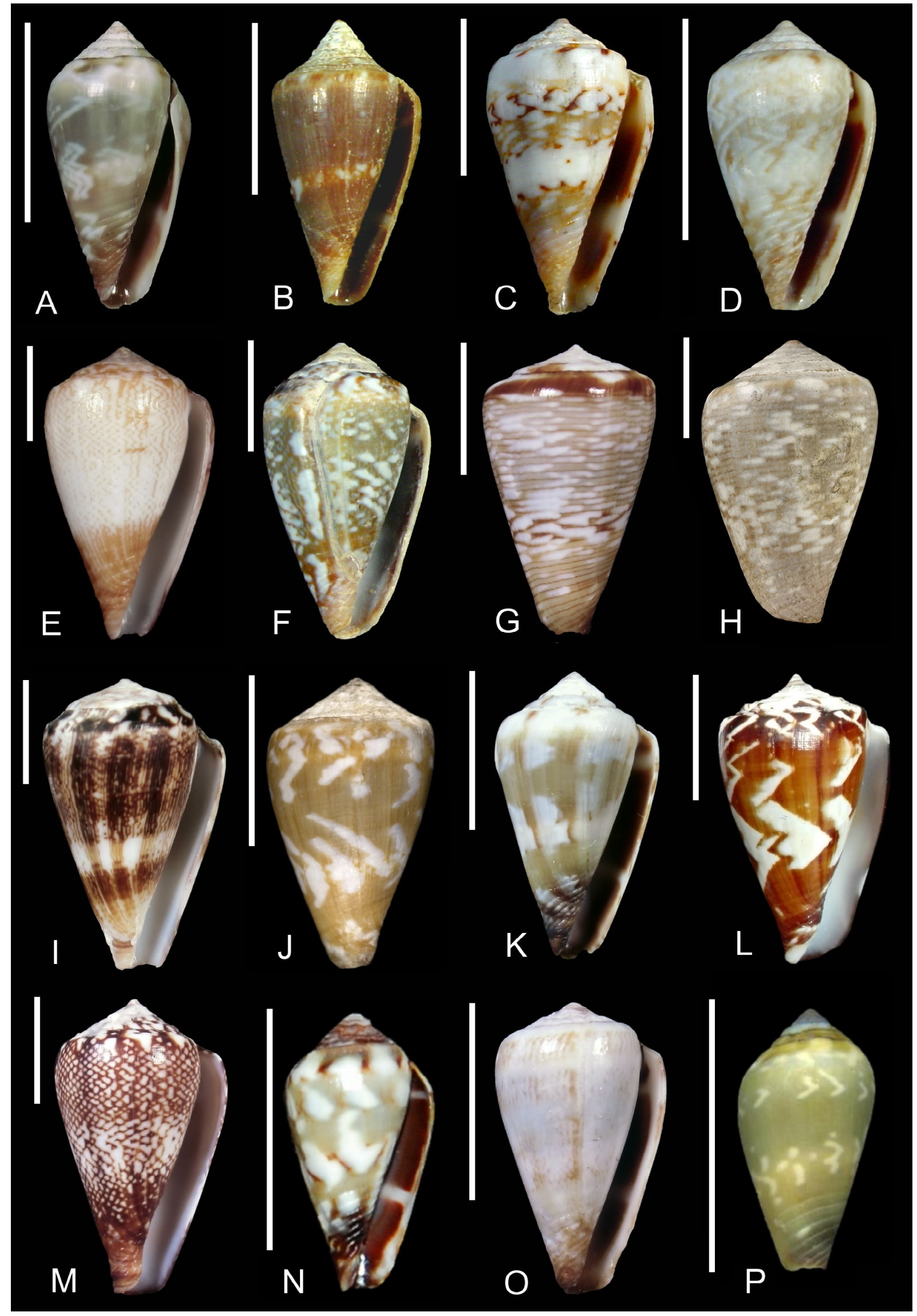


Africonus wandae Cossignani, 2014: 22. syn. nov.

Africonus pedrofiadeiroi Cossignani \& Fiadeiro, 2015a: 18. syn. nov.

Conus borgesi - Monteiro et al. 2004: 30, pl. 116-117.

\section{Material examined}

\section{Holotype}

CABO VERDE • 26.1 mm; Boa Vista Island, Baía das Gatas; 2 m depth; NHMUK 1986196.

\section{Other material}

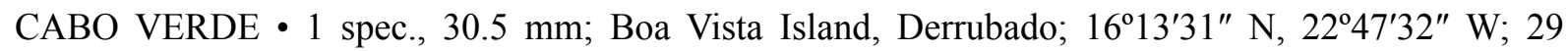
Jun. 2013; MNCN exped.; MNCN 15.05/88646 (Fig. 3E) • 1 spec.; Boa Vista Island, Porto Ferreira; $16^{\circ} 7^{\prime} 45^{\prime \prime} \mathrm{N}, 22^{\circ} 40^{\prime} 17^{\prime \prime} \mathrm{W}$; MNCN exped.; GenBank mitochondrion, partial genome: NC_013243; MNCN ADN/6990 • 1 spec., 27.4 mm, holotype of Africonus wandae; Boa Vista Island, Baía Grande; MMM • 1 spec., $24.7 \mathrm{~mm}$, holotype of Africonus pedrofiadeiroi; Boa Vista Island, Curral Velho to Ilhéu de Galeão; 1 to 5 m depth; MMM.

\section{Geographical distribution}

Multiple localities around Boa Vista Island, Cabo Verde Archipelago.

\section{Conservation status in IUCN Red List}

Least concern.

\section{Remarks}

This species is widely distributed around the island of Boa Vista. Differences in color pattern have been invoked for the introduction of new names for certain local populations from the southeast and south coasts of the island without further justification. We hereby consider these names as synonyms. Thus, specimens matching the type material of Africonus wandae were studied in detail in Tenorio et al. (2014), and their haplotypes (coxl gene fragment) showed to be identical with that of A. borgesi. The holotype of Africonus pedrofiadeiroi exhibits a white middle band patterned with minute brown zigzag markings, a feature characteristic of $A$. borgesi, which is considered conspecific.

Africonus borgesi and A. josephinae are very closely related according to the phylogeny. They belong to a lineage that contains species from Boa Vista and Maio islands, and is the sister group to the remaining Africonus.

Africonus calhetae (Rolán, 1990)

Fig. 3F

Conus navarroi calhetae Rolán, 1990: 41, pl. 1, fig. 7.

Conus navarroi calhetae - Monteiro et al. 2004: 63, pl. 151.

\section{Material examined}

\section{Holotype}

CABO VERDE • 26.8 mm; Maio Island, Baía de Pau Seco; E. Rolán leg.; MNCN 15.05/1096 (Fig. 3F).

\section{Other material}

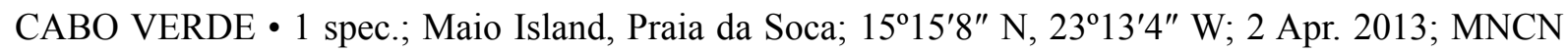
exped.; GenBank mitochondrion, partial genome: MF491534; MNCN 15.05/78798 • 1 spec.; same 
TENORIO M.J. et al., Taxonomic revision of West African cone snails

collection data as for preceding; 2 Apr. 2013; MNCN exped.; GenBank mitochondrion, partial genome: MF491533; MNCN 15.05/78787.

\section{Geographical distribution}

Between Calheta and Baía do Navío Quebrado, in the western and northwestern coast of Maio Island, Cabo Verde Archipelago.

\section{Conservation status in IUCN Red List}

Least concern.

\section{Remarks}

This taxon was initially introduced as a subspecies, i.e., Conus navarroi calhetae Rolán, 1990, due to morphological similarities in shell and radula between the populations from São Vicente and Maio islands. However, these disjunct populations are genetically distant. The closest relative according to the phylogeny is the parapatric taxon A. galeao.

Africonus crotchii (Reeve, 1849)

Fig. 3G

Conus crotchii Reeve, 1849: pl. VI, sp. 254.

Conus irregularis G.B. Sowerby II, 1858: 29, pl. 18 (204), figs 418-419.

Conus salreiensis Rolán, 1980: 84, pl. 2, fig. 1.

Conus iberogermanicus Röckel et al., 1980a: 75, figs 48-50.

Conus poppei Elsen, 1983: 185, fig. 5.

Conus teodorae Rolán \& Fernandes in Rolán, 1990: 17, pl. 1, fig. 5.

Conus evorai Monteiro et al., 1995: 8, pl. 1-4.

Africonus fiadeiroi Tenorio et al., 2014: 12, pl. 3.

Africonus condei Afonso \& Tenorio, 2014: 52, pl. 3, figs 1-7.

Africonus antonioi Cossignani, 2014: 28. syn. nov.

Africonus cabraloi Cossignani, 2014: 23.

Africonus calhetinensis Cossignani \& Fiadeiro, 2014b: 22. syn. nov.

Africonus docensis Cossignani \& Fiadeiro, 2014b: 24.

Africonus josegeraldoi Cossignani \& Fiadeiro, 2018a: 17. syn. nov.

Conus crotchii - Monteiro et al. 2004: 35, pls 112 and 157.

Conus evorai - Monteiro et al. 2004: 42, pl. 79.

Conus irregularis - Monteiro et al. 2004: 53, pls 100-102, pl. 103, figs 2-3, 5.

Conus salreiensis - Monteiro et al. 2004: 35, pls 112 and 157.

Conus teodorae - Monteiro et al. 2004: 75, pl. 80.

\section{Material examined}

Holotype (not examined)

Holotype was in collection H. Cuming, present whereabouts unknown; reference is figure 254 on plate 6 of Reeve (1849). Three specimens in the NHMUK type collection were formerly labeled as "probable syntypes", but these were not part of the type material. Given the relevance of this polymorphic taxon as an important reference for the Cabo Verde cone fauna, we hereby designate a neotype matching the figure in Reeve (1849). The originally stated type locality "Saldanha Bay, South Africa" was erroneous and it was corrected to Santa Mónica, Boa Vista Island, Cabo Verde Archipelago (Coomans et al. 1985a). 
Neotype (here designated)

CABO VERDE • 22.5 mm; Boa Vista Island, Santa Mónica; 1559'0" N, 2253'11" W; 22 Apr. 2015; MNCN exped.; MNCN 15.05/79971 (Fig. 3G).

\section{Other material}

CABO VERDE - 1 spec.; Boa Vista Island, Morro de Areia; 16² $24^{\prime \prime}$ N, 22 $2^{\circ} 7^{\prime} 7^{\prime \prime}$ W; 22 Apr. 2015; MNCN exped.; GenBank mitochondrion, partial genome: MF491591; MNCN 15.05/79944 • 1 spec.; same collection data as for preceding; GenBank mitochondrion, partial genome: MF491593;

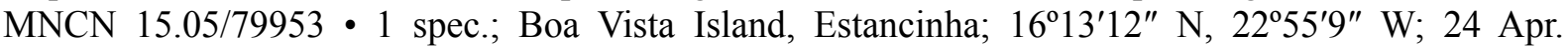
2015; MNCN exped.; GenBank mitochondrion, partial genome: MF491598; MNCN 15.05/80004 • 1 spec.; same collection data as for preceding; GenBank mitochondrion, partial genome: MF491597; MNCN 15.05/79997 • 1 spec.; same collection data as for preceding; GenBank mitochondrion, partial genome: MF491596; MNCN 15.05/79994 - 1 spec.; Boa Vista Island, Derrubado; 16²13'31" N, $22^{\circ} 47^{\prime} 17^{\prime \prime}$ W; 29 Jun. 2013; MNCN exped.; GenBank mitochondrion, partial genome: MF491542; MNCN 15.05/80392 - 1 spec.; Boa Vista Island, Praia Zebraca (near Ilhéu do Galeão); $16^{\circ} 12^{\prime} 6^{\prime \prime} \mathrm{N}$, $22^{\circ} 42^{\prime} 40^{\prime \prime}$ W; 30 Jun. 2013; MNCN exped.; GenBank mitochondrion, partial genome: MF491549; MNCN 15.05/80399 • 1 spec.; Boa Vista Island, Água Doce; 16²12'29" N, 2244'7" W; 19 Apr. 2015; MNCN exped.; GenBank mitochondrion, partial genome: MF491588; MNCN 15.05/79894 - 1 spec.; Boa Vista Island, Derrubado (bay West); 16 $13^{\prime} 22^{\prime \prime}$ N, 22 $47^{\prime} 41^{\prime \prime}$ W; 29 Jun. 2013; MNCN exped.; GenBank mitochondrion, partial genome: MF491545; MNCN 15.05/80395 • 1 spec.; Boa Vista Island,

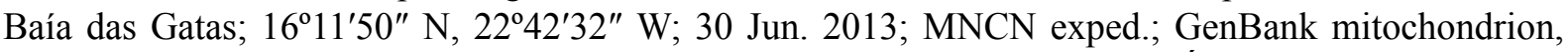
partial genome: MF491550; MNCN 15.05/80400 • 1 spec.; Boa Vista Island, Água Doce; $16^{\circ} 12^{\prime 2} 29^{\prime \prime} \mathrm{N}$, $22^{\circ} 44^{\prime} 7^{\prime \prime} \mathrm{W}$; 19 Apr. 2015; MNCN exped.; GenBank mitochondrion, partial genome: MF491588; MNCN

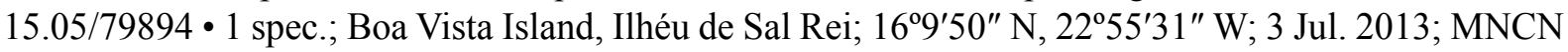
exped.; GenBank mitochondrion, partial genome: MF491564; MNCN 15.05/80414 • $1 \mathrm{spec}$., $21.0 \mathrm{~mm}$, holotype of Africonus antonioi; Boa Vista Island, Baía Pequena; MMM • 1 spec., $11.2 \mathrm{~mm}$, holotype of Africonus calhetinhensis; Boa Vista Island, Baía de Calhetinha Ilhéu do Galeão; MMM • 1 spec., 18 mm, holotype of Africonus josegeraldoi; Boa Vista Island, Baixa de Padaroso; MMM.

\section{Geographical distribution}

Multiple localities around Boa Vista Island, Cabo Verde Archipelago.

\section{Conservation status in IUCN Red List}

Endangered. Status revision required.

\section{Remarks}

The name crotchii has traditionally been applied to specimens from southwest Boa Vista Island matching figure 254 in Reeve (1849). However, based upon molecular phylogenetic studies, this has now been found to be the most senior name applicable to a large clade of specimens from multiple localities around Boa Vista Island with a very large phenotypic variability in shell pattern. Differences in radular morphology among the members of this clade are, however, rather subtle in agreement with the low DNA sequence divergence. This clade includes representative individuals of no less than 14 taxon names, which are now considered to be synonym (color forms) of the nominal taxon. Thus, the taxon $A$. salreiensis, which was initially classified within the category 'critically endangered' in the IUCN Red List, now shows to be a mere color form of $A$. crotchii distributed in and around the Sal Rei area in northwest Boa Vista Island. Similarly, the taxon $A$. irregularis also now becomes a junior syonym of $A$. crotchii. In the mitogenome phylogeny, the analyzed individuals of $A$. irregularis from different populations appear distributed in two separate clades. Most of the individuals fell into the $A$. crotchii clade, whereas two were recovered within the $A$. maioensis clade. In order to attribute the senior name to each of the clades, 
TENORIO M.J. et al., Taxonomic revision of West African cone snails

we needed first to identify which of the analyzed individuals matched the available type material of A. irregularis. There is a series of three syntypes of this taxon at the NHMUK "from West Africa" as the type locality. We hereby designate the specimen 197871/1 (dimensions: $28.3 \times 18.1 \mathrm{~mm}$ ) in the series as lectotype for the taxon Conus irregularis G.B. Sowerby II, 1858 (Fig. 3H). Specimens 197871/2 and 197871/3 from the same lot became paralectotypes. We consider that the specimens identified as A. irregularis from Estancinha, near Ponta do Sol in northwest Boa Vista match the type series at the NHMUK, and hence we propose a change in the type locality to Estancinha, north of Sal Rei, Boa Vista Island, Cabo Verde Archipelago. The sequenced specimens of A. irregularis from Baía das Gatas, Morro de Areia and Estancinha were recovered within the A. crotchii clade, which becomes the senior name for this taxon. Being a polymorphic species, many of the recently introduced names could be assigned to the taxon $A$. crotchii. Thus, $A$. antonioi and $A$. josegeraldo $i$ are morphologically related to $A$. crotchii form fiadeiro $i$, whereas the green color and small size of $A$. calhetinhensis most likely correspond to a juvenile specimen of the highly variable $A$. crotchii form irregularis.

Africonus cuneolus (Reeve, 1843)

Fig. 3I

Conus cuneolus Reeve, 1843: pl. 37, sp. 205.

Conus anthonyi Petuch, 1975a: 263, figs 5-6.

Conus pseudocuneolus Röckel et al., 1980a: 117, figs 96-99.

Conus fontonae Rolán \& Trovão in Rolán, 1990: 28, pl. 1, fig. 10.

Conus mordeirae Rolán \& Trovão in Rolán, 1990: 25, pl. 1, fig. 11.

Conus serranegrae Rolán, 1990: 49, pl. 1, fig. 15.

Africonus bernardinoi Cossignani, 2014: 24.

Conus cuneolus - Monteiro et al. 2004: 36, pls 64-65.

Conus fontonae - Monteiro et al. 2004: 45, pl. 69.

Conus mordeirae - Monteiro et al. 2004: 61, pls 66-68.

Conus serranegrae - Monteiro et al. 2004: 72, pl. 73.

Conus cuneolus form A - Röckel et al. 1980a: 99, pl. 5, row 4.

Conus cuneolus form C - Röckel et al. 1980a: 103, pl. 5, row 5.

Conus cuneolus form D - Röckel et al. 1980a: 105, pl. 5, row 6.

Conus cuneolus form G - Röckel et al. 1980a: 107, pl. 5, row 3.

Conus cuneolus form H - Röckel et al. 1980a: 109, pl. 5, row 2.

\section{Material examined}

Lectotype

CABO VERDE • 33 mm; Sal Island (Coomans et al. 1985a); NHMUK 196180.

\section{Other material}

CABO VERDE • 1 spec., 28.2 mm; Sal Island, Calheta Funda; 16³9'6" N, 22 $56^{\circ} 53^{\prime \prime}$ W; 5 Apr. 2014; MNCN exped.; GenBank mitochondrion, partial genome: MF491569; MNCN 15.05/79712 (Fig. 3I) - 1 spec.; Sal Island, Santa Maria; 16 $6^{\circ} 35^{\prime} 38^{\prime \prime}$ N, 2253'36" W; 9 Apr. 2014; MNCN exped.; GenBank mitochondrion, partial genome: MF491583; MNCN 15.05/79844 • 1 spec.; Sal Island, Ilhéus do Chano; 16 $41^{\prime} 37^{\prime \prime}$ N, 22 $52^{\prime} 47^{\prime \prime}$ W; 8 Apr. 2014; MNCN exped.; GenBank mitochondrion, partial genome:

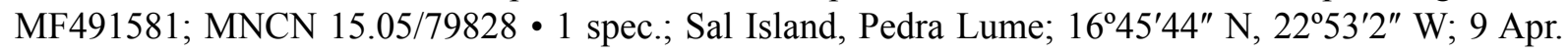
2014; MNCN exped.; GenBank mitochondrion, partial genome: MF491582; MNCN 15.05/79835 • 1 spec.; Sal Island, Baía da Fontona; 16 $44^{\prime} 22^{\prime \prime}$ N, 22 $2^{\circ} 8^{\prime} 46^{\prime \prime}$ W; 6 Apr. 2014; MNCN exped.; GenBank mitochondrion, partial genome: MF491575; MNCN 15.05/79764 • 1 spec.; Sal Island, Baía do 
Roucamento; 16 41'20" N, 22 $56^{\prime} 24^{\prime \prime}$ W; 5 Apr. 2014; MNCN exped.; GenBank mitochondrion, partial genome: MF491580; MNCN 15.05/79814 • 1 spec.; Sal Island, Serra Negra; 16³8'17" N, 22 53'56" W; 9 Apr. 2014; MNCN exped.; GenBank mitochondrion, partial genome: MF491571; MNCN 15.05/79729

- 1 spec.; same collection data as for preceding; 5 Apr. 2014; MNCN exped.; GenBank mitochondrion, partial genome: MF491570; MNCN 15.05/79719.

\section{Geographical distribution}

Multiple localities to the west, south and east of Sal Island, Cabo Verde Archipelago, including Fontona, Murdeira, Algodoeiro, Santa Maria, Serra Negra, Parda and Pedra Lume.

\section{Conservation status in IUCN Red List}

Endangered. Status revision required.

\section{Remarks}

The taxon A. cuneolus was the earliest name introduced for an endemic Cabo Verde cone species. It was already considered in Röckel et al. (1980a) as an extremely polymorphic species. These authors assigned a total of 13 forms of $A$. cuneolus labeled with capital letters A to M. All these forms/species were widely distributed throughout most islands of the Cabo Verde Archipelago. However, several phylogenetic studies (Cunha et al. 2005; Abalde et al. 2017a) indicate that the taxon A. cuneolus is actually endemic to Sal Island. Several authors (Rolán 1990; Rolán \& Trovão in Rolán 1990; Cossignani 2014) have reported the occurrence of several species of cones within the group of forms of A. cuneolus from Sal Island and introduced new names accordingly. Most of these are members of a compact clade with very small genetic divergence from typical $A$. cuneolus. These taxa names are therefore considered junior synonyms of the latter, which can be regarded as a highly polymorphic species consistent with the proposal of Röckel et al. (1980a).

\section{Africonus curralensis (Rolán, 1986)}

Figs 3J, 5K

Conus curralensis Rolán, 1986: 10, fig. 1B.

Conus curralensis - Monteiro et al. 2004: 36, pl. 86.

Conus decoratus form D (not C. decoratus Röckel, Rolán \& Monteiro, 1980) - Röckel et al. 1980a: 63, pl. 2, row 2a-b, figs 30(4), 33 .

\section{Material examined}

\section{Holotype}

CABO VERDE • 17 mm; Santa Luzia Island, Curral; 1-3 m depth; E. Rolán leg.; MNCN 15.05/1010 (Fig. 3J).

\section{Other material}

CABO VERDE • 1 spec., 23 mm; Santa Luzia Island, Curral; 1646'23" N, 244ㄱ'13" W; 14 Apr. 2016; MNCN exped.; GenBank mitochondrion, partial genome: MT240806; MNCN 15.05/78591 (Fig. 5K).

\section{Geographical distribution}

Southwest coast of Santa Luzia Island, Cabo Verde Archipelago.

\section{Conservation status in IUCN Red List}

Near threatened. 


\section{Remarks}

It was initially reported in Röckel et al. (1980a) as Conus decoratus form D. In the phylogenetic tree, it belongs to the same clade as A. decoratus, but appears only distantly related. A distinctive color form living sympatrically in Santa Luzia Island was initially confused with this species in Abalde et al. (2017a). The sequencing of a specimen fully matching the holotype of $A$. curralensis has shown that the alleged color form is actually a separate, sister species that is introduced hereby with the name Africonus insulae sp. nov. (see below).

\section{Africonus damottai (Trovão, 1979)}

Fig. 3K

Conus damottai Trovão, 1979: 6, pl. 1, fig. 4.

Conus derrubado Rolán \& Fernandes in Rolán, 1990: 19, pl. 2, fig. 4.

Africonus diegoi Cossignani, 2014: 26. syn. nov.

Africonus umbelinae Cossignani \& Fiadeiro, 2014b: 22.

Africonus roquensis Cossignani \& Fiadeiro, 2015b: 5. syn. nov.

Africonus pinedensis Cossignani \& Fiadeiro, 2017a: 34. syn. nov.

Africonus purvisi Cossignani \& Fiadeiro, 2017a: 32. syn. nov.

Conus damottai - Monteiro et al. 2004: 37, pls 88-89.

\section{Material examined}

\section{Holotype}

CABO VERDE • 20.6 mm; Boa Vista Island, Baía das Gatas; 2 m depth; NHMUK 1986197.

\section{Other material}

CABO VERDE • 1 spec., $18.2 \mathrm{~mm}$; Boa Vista Island, Baía das Gatas; 16 $11^{\prime} 50^{\prime \prime} \mathrm{N}, 22^{\circ} 42^{\prime} 32^{\prime \prime}$ W; 30 Jun. 2013; MNCN exped.; GenBank mitochondrion, partial genome: MF491551; MNCN 15.05/80401 (Fig. 3K)

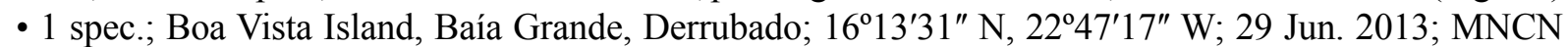
exped.; GenBank mitochondrion, partial genome: MF491543; MNCN 15.05/80393 • 1 spec.; Boa Vista Island, Espingueira; 16 $6^{\circ} 12^{\prime} 55^{\prime \prime} \mathrm{N}, 22^{\circ} 47^{\prime} 49^{\prime \prime} \mathrm{W}$; 19 Apr. 2015; MNCN exped.; GenBank mitochondrion, partial genome: MF491589; MNCN 15.05/79904 • 1 spec., 13.2 mm, holotype of Africonus diegoi; Boa Vista Island, João Barbosa; MMM • 1 spec., 21.7 mm, holotype of Africonus roquensis; Boa Vista Island, Ponta do Roque; MMM • 1 spec., $16.2 \mathrm{~mm}$, holotype of Africonus pinedensis; Boa Vista Island, Pinedo; MMM 1 spec., 16.2 mm, holotype of Africonus purvisi; Boa Vista Island, Praia do Canto; MMM.

\section{Geographical distribution}

Multiple localities around Boa Vista Island, Cabo Verde Archipelago.

\section{Conservation status in IUCN Red List}

Least concern.

\section{Remarks}

This species is widely distributed around Boa Vista Island, with a high variability in shell pattern. This polymorphism has led to the introduction of several taxa names associated with certain populations, which are all considered synonyms hereby. Thus, the holotypes of $A$. diegoi and $A$. roquensis exhibit all the shell features characteristic of $A$. damottai (just a more elongated shell shape in the case of $A$. diegoi, which does not justify separation at the species level). The holotype of $A$. purvisi most likely represents a juvenile specimen of $A$. damottai, whereas the holotype of $A$. pinedensis resembles certain variations of A. damottai with a well-developed color pattern (i.e., Monteiro et al. 2004: pl. 89). The taxon A. galeao from Maio Island was initially introduced as a subspecies of $A$. damottai. Despite the morphological 
similarities in shell pattern and radular tooth, the phylogenetic analyses indicate that A. galeao can be regarded as a separate, valid full species.

Africonus decoratus (Röckel, Rolán \& Monteiro, 1980)

Fig. 3L, 5L

Conus decoratus Röckel et al., 1980a: 61, pl. II, figs 29-33.

Conus decoratus - Monteiro et al. 2004: 38, pls 119-120, figs 1-2, 4-8.

\section{Material examined}

Holotype

CABO VERDE • $20.6 \mathrm{~mm}$; São Vicente Island, Matiota Beach; 1 to $3 \mathrm{~m}$ depth; NMSF.

\section{Other material}

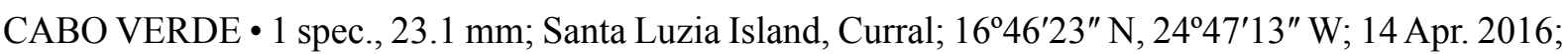
MNCN exped.; GenBank mitochondrion, partial genome: MF491603; MNCN 15.05/78589 (Fig. 3L) •

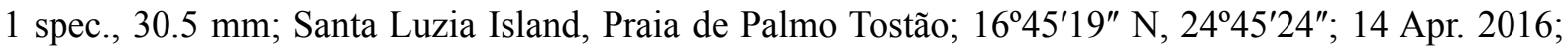
MNCN exped.; MNCN 15.05/78578 (Fig. 5L).

\section{Geographical distribution}

Calhau to Saragaça, on the southeast coast of São Vicente Island, and Curral area, on the southwest coast of Santa Luzia Island, Cabo Verde Archipelago.

\section{Conservation status in IUCN Red List}

Vulnerable.

\section{Remarks}

This species belongs to a lineage that includes species endemic to the westernmost islands in the Cabo Verde Archipelago and is sister to species from Santiago and Maio islands. Despite obvious differences in shell morphology, the species sister to A. decoratus according to the phylogeny is A. grahami. The type locality from which $A$. decoratus was originally described is now part of a large and touristic urban area in the vicinity of the modern Port of Mindelo. This population (decoratus form A in Röckel et al. 1980a) is believed to be now extinct, but specimens from other population (decoratus form B in Röckel et al. 1980a) are occasionally found on the east coast of São Vicente Island from Calhau to Saragaça, and more commonly on the deserted island of Santa Luzia, where the specimens used in the present study were collected. This beautifully patterned species shows some degree of variation in its background color, which ranges from light brown to black.

\section{Africonus delanoyae (Trovão, 1979)}

Fig. 3M

Conus delanoyi Trovão, 1979: 3, pl. 1, fig. 1.

Conus luquei Rolán, 1990: 50, pl. 2, fig. 2.

Africonus joserochoi Cossignani, 2014: 27. syn. nov.

Africonus swinneni Tenorio, Afonso, Cunha \& Rolán, 2014: 10, pl. 2.

Conus delanoyae - Monteiro et al. 2004: 39, pl. 77.

Conus cuneolus form B (not C. cuneolus Reeve, 1843) - Röckel et al. 1980a: 101, pl. 7, row 1. 
TENORIO M.J. et al., Taxonomic revision of West African cone snails

\section{Material examined}

Holotype

CABO VERDE • 27.2 mm; Boa Vista Island, Baía das Gatas; 1.5 m depth; NHMUK 1986194.

\section{Other material}

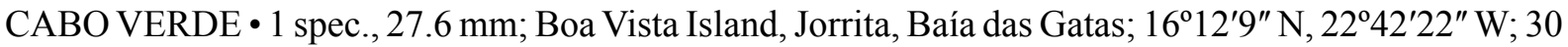
Jun. 2013; MNCN exped.; GenBank mitochondrion, partial genome: MF491547; MNCN 15.05/80397 (Fig. 3M) • 1 spec.; Boa Vista Island, Praia Canto; 16 $11^{\prime} 10^{\prime \prime}$ N, 22 $2^{\circ} 42^{\prime} 28^{\prime \prime}$ W; 30 Jun. 2013; MNCN exped.; GenBank mitochondrion, partial genome: MF491552; MNCN 15.05/80402 • 1 spec.; Boa Vista Island, Porto Ferreira; $16^{\circ} 7^{\prime} 45^{\prime \prime}$ N, 22 $2^{\circ} 40^{\prime} 17^{\prime \prime} \mathrm{W}$; 1 Jul. 2013; MNCN exped.; GenBank mitochondrion, partial genome: MF491556; MNCN 15.05/80406 • 1 spec., $21.0 \mathrm{~mm}$, holotype of Africonus joserochoi; Boa Vista Island, Calheta; MMM.

\section{Geographical distribution}

Northeast coast to Porto Ferreira on the East coast of Boa Vista Island, Cabo Verde Archipelago.

\section{Conservation status in IUCN Red List}

Least concern.

\section{Remarks}

This species was originally described from the population at Baía das Gatas in Boa Vista Island, and the shell color is characterized by a pattern of numerous small irregular dots on a light to dark brown background. It was treated in Röckel et al. (1980a) as Conus cuneolus form B. Other populations of cones around the northeast and east of Boa Vista Island, introduced recently as separate species, exhibit very distinct shell patterns but share the same elongated radular tooth morphology observed in A. delanoyae (Tenorio et al. 2014). Representative specimens of these taxa examined molecularly exhibit mitogenome sequences almost identical to that of $A$. delanoyae, and can be considered conspecific. Additionally, the type material of $A$. joserochoi is fully consistent with the concept of $A$. delanoyae. The author stated that the main features separating $A$. joserochoi from A. delanoyae were the relative height of the spire (always eroded) and the "less triangular and more pyriform shell shape" in the former. However, no morphometric data are given, nor were these differences statistically tested, so there is no sufficient evidence to consider $A$. joserochoi as a separate species from $A$. delanoyae. We can conclude that $A$. delanoyae is a polymorphic species, only distantly related to $A$. cuneolus, comprising several well-defined forms with characteristic shell patterns, sharing the same radular morphology and mitogenome sequence. The sister species $A$. vulcanus is separated by a genetic uncorrected $p$ distance of $0.3 \%$, slightly above the threshold used to delimit species. Given the different radular morphology (radular tooth broad and robust in vulcanus, but narrow and elongated in delanoyae) we consider them tentatively separate species in spite of the close genetic proximity.

Africonus denizi Afonso \& Tenorio, 2011

Fig. 3N

Africonus denizi Afonso \& Tenorio, 2011: 127, pl. 1, figs 1-8

\section{Material examined}

Holotype

CABO VERDE • 11.6 mm; São Vicente Island, Praia Grande; C.M.L. Afonso leg.; MNCN 15.05/60000 (Fig. $3 \mathrm{~N}$ ). 
Other material

CABO VERDE • 1 spec.; São Vicente Island, Praia Grande; 1651'40" N, 2452'30" W; 17 Apr. 2016; MNCN exped.; GenBank mitochondrion, partial genome: MF491543; MNCN 15.05/80393.

\section{Geographical distribution}

Northeast coast of São Vicente Island at Praia Grande, Cabo Verde Archipelago.

\section{Conservation status in IUCN Red List}

Near threatened.

\section{Remarks}

This small-sized species is morphologically similar to A. miruchae from Sal Island, which is however only distantly related. In the phylogeny, it was recovered as sister to the recently described $A$. freitasi, a morphologically related allopatric species. So far, it has only been found at the type locality.

\section{Africonus diminutus (Trovão \& Rolán, 1986)}

Fig. $3 \mathrm{O}$

Conus diminutus Trovão \& Rolán, 1986: 10, figs 3a-c.

Africonus morroensis Cossignani \& Fiadeiro, 2014a: 17.

Conus diminutus - Monteiro et al. 2004: 40, pls 96-97.

\section{Material examined}

Holotype (not examined)

Holotype (type locality: Cabo Verde; Boa Vista Island, Baía de Sal Rei; intertidal to $1 \mathrm{~m}$ depth) stated to be at MNCN in Trovão \& Rolán (1986), but apparently it was never deposited (as per a note in the collection). Instead, a lot of three paratypes was present, with registration number MNCN 15.05/1011. We have selected the specimen from which the mitogenome was sequenced as neotype for the taxon Conus diminutus Trovão \& Rolán, 1986.

Neotype (here designated)

CABO VERDE • $14.8 \mathrm{~mm}$; Boa Vista Island, Ilheu de Sal Rei; 16 $9^{\prime} 50^{\prime \prime}$ N, 22 $2^{\circ} 55^{\prime} 31^{\prime \prime}$ W; 3 Jul. 2013; MNCN exped.; GenBank mitochondrion, partial genome: MF491566; MNCN 15.05/80416 (Fig. 3O).

\section{Other material}

CABO VERDE • 1 spec.; Boa Vista Island, Morro de Areia; 16 $5^{\prime 2} 24^{\prime \prime}$ N, 22 $2^{\circ} 57^{\prime} 7^{\prime \prime}$ W; 3 Jul. 2013; MNCN exped.; GenBank mitochondrion, partial genome: MF491594; MNCN 15.05/79960.

\section{Geographical distribution}

West and northwest coast of Boa Vista Island, Cabo Verde Archipelago.

\section{Conservation status in IUCN Red List}

Near threatened. Status revision required.

\section{Remarks}

Africonus diminutus is a small, highly variable species endemic to the west coast of Boa Vista Island. Whereas typical specimens of $A$. diminutus are found around the locality of Sal Rei, specimens from Morro de Areia introduced under the name A. morroensis exhibit almost identical mitogenome 
sequences despite the variations in shell morphology, and are considered conspecific with A. diminutus. This represents a significant expansion of the distribution range for the species. According to the reconstructed phylogeny, $A$. diminutus is sister to $A$. boavistensis, also very variable in shell pattern and widely distributed around Boa Vista Island.

Africonus espingueirensis Cossignani \& Fiadeiro, 2017

Fig. 3P

Africonus espingueirensis Cossignani \& Fiadeiro, 2017a: 30.

Material examined

Holotype

CABO VERDE・9.7 mm; Boa Vista Island, Espingueira; MMM (Fig. 3P).

\section{Geographical distribution}

Only known from the type locality.

\section{Conservation status in IUCN Red List}

Not evaluated.

\section{Remarks}

This species has not been examined molecularly. It is morphologically similar to A. antoniaensis, but smaller sized. Radular examination (E. Rolán, pers. com. to MJT) indicated a fully-developed, mature tooth for such a small-sized shell, consistent with that of an adult individual. This observation rules out the possibility of this taxon being a juvenile of another species. We hereby consider it as provisionally valid, pending confirmation by molecular studies.

Africonus felitae (Rolán, 1990)

Fig. 4A

Conus felitae Rolán, 1990: 45, pl. 1, fig. 18.

Conus felitae - Monteiro et al. 2004: 43, pl. 74.

Material examined

Holotype

CABO VERDE • 12.7 mm; Sal Island, Rabo de Junco, extreme north of Baía de Murdeira; E. Rolán leg.; MNCN 15.05/1099 (Fig. 4A).

\section{Other material}

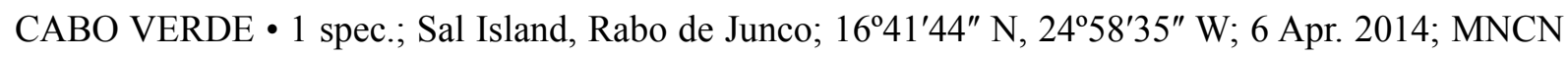
exped.; GenBank mitochondrion, partial genome: MF491573; MNCN 15.05/79744.

\section{Geographical distribution}

Only known from the type locality at Sal Island, Cabo Verde Archipelago.

\section{Conservation status in IUCN Red List}

Vulnerable. 


\section{Remarks}

This small-sized species endemic to Sal Island is closely related to $A$. cuneolus. Its distinctive shell and radular morphology as well as the phylogenetic data are consistent with its status as a valid species with a very reduced distribution range.

Africonus fernandesi (Tenorio, Afonso \& Rolán, 2008)

Fig. 4B

Conus fernandesi Tenorio et al., 2008: 5, pl. 2.

Conus cuneolus form K (not C. cuneolus Reeve, 1843) - Röckel et al. 1980a: 111, pl. 6, row 3.

\section{Material examined}

\section{Holotype}

CABO VERDE • $21.0 \mathrm{~mm}$; Santo Antão Island, Porto Novo; $17^{\circ} 01^{\prime} 2^{\prime \prime} \mathrm{N}, 2^{\circ} 03^{\prime} 37^{\prime \prime} \mathrm{W} ; 2-4 \mathrm{~m}$ depth; E. Rolán leg.; MNCN 15.05/47052.

\section{Other material}

CABO VERDE • 1 spec., $14.5 \mathrm{~mm}$; Santo Antão Island, Porto Novo; $17^{\circ} 01^{\prime} 4^{\prime \prime} \mathrm{N}, 25^{\circ} 03^{\prime 2} 22^{\prime \prime} \mathrm{W} ; 15$ Apr. 2016; MNCN exped.; GenBank mitochondrion, partial genome: MF491604; MNCN 15.05/78598 (Fig. 4B).

\section{Geographical distribution}

South coast of Santo Antão Island, Cabo Verde Archipelago.

\section{Conservation status in IUCN Red List}

Endangered.

\section{Remarks}

Prior to its introduction as a full species, it was referred to as Conus cuneolus form K in Röckel et al. (1980a). Molecular data clearly confirm that it is a valid species endemic to Santo Antão Island, where it lives in the vicinity of Porto Novo harbor in rocky areas. In the tree, it is recovered as sister to A. curralensis and A. insulae sp. nov. from Santa Luzia Island.

Africonus freitasi Tenorio, Afonso, Rolán, Pires, Vasconcelos, Abalde \& Zardoya, 2018 Fig. 4C

Africonus freitasi Tenorio et al., 2017: 37, fig. 3a-k.

Conus sp. - Röckel et al. 1980a: 90-91, fig. 66.

\section{Material examined}

\section{Holotype}

CABO VERDE • 13.7 mm; São Vicente Island, Calhau; 16 51'7" N, 2451'59" W; MNCN exped.; MNCN 15.05/200008 (Fig. 4C).

\section{Other material}

CABO VERDE - 1 spec., $14.5 \mathrm{~mm}$; same collection data as for holotype; 12 Apr. 2016; GenBank mitochondrion, partial genome: MF491601; MNCN 15.05/78562. 


\section{Geographical distribution}

From Calhau to Saragaça, southeast coast of São Vicente Island, Cabo Verde Archipelago.

\section{Conservation status in IUCN Red List}

Not evaluated.

\section{Remarks}

This small-sized species is morphologically similar to A. miruchae from Sal Island, and to A. denizi. Phylogenetic analyses show that $A$. freitasi, A. denizi and $A$. miruchae are distinct species despite their partial similarity in shell morphology. The phenotypic resemblance of the shell of $A$. freitasi to A. miruchae is possibly the result of convergence, whereas the similarity to $A$. denizi may reflect their close phylogenetic relationship, sharing a relatively recent last common ancestor.

Africonus furnae (Rolán, 1990)

Fig. 4D

Conus verdensis furnae Rolán, 1990: 42, pl. 1, fig. 9.

Conus verdensis furnae - Monteiro et al. 2004: 81, pl. 82, figs 1-5, 7-8.

\section{Material examined}

\section{Holotype}

CABO VERDE • 21.1 mm; Brava Island, Baía de Furna; E. Rolán leg.; MNCN 15.05/1097 (Fig. 4D).

\section{Geographical distribution}

Pedrinha and Furna, Brava Island, Cabo Verde Archipelago.

\section{Conservation status in IUCN Red List}

Least concern.

\section{Remarks}

This taxon was initially introduced as a subspecies of $A$. verdensis. This species has not been examined molecularly. However, the geographic isolation of Brava Island within the Cabo Verde Archipelago together with the distinctive morphology of shell and radula suggest that this is most likely a valid species, well differentiated in genetic distance from $A$. verdensis.

\section{Africonus fuscoflavus (Röckel, Rolán \& Monteiro, 1980)}

Fig. 4E

Conus fuscoflavus Röckel et al., 1980a: 71, figs 38-41.

Conus messiasi Rolán \& Fernandes in Rolán, 1990: 17, pl. 1, fig. 6.

Conus fantasmalis Rolán, 1990: 37, pl. 1, fig. 8.

Africonus silviae Cossignani, 2014: 19.

Africonus cristinapessoae Cossignani \& Fiadeiro, 2017a: 27. syn. nov.

Africonus gallopalvoi Cossignani \& Fiadeiro, 2017a: 31. syn. nov.

Africonus tarafensis Cossignani \& Fiadeiro, 2018c: 32. syn. nov.

Conus fuscoflavus - Monteiro et al. 2004: 46, pl. 106. 
Conus messiasi-Monteiro et al. 2004: 59, pl. 105.

Conus fantasmalis - Monteiro et al. 2004: 43, pl. 113.

\section{Material examined}

Holotype

CABO VERDE • 20.3 mm; Boa Vista Island, Sal Rei; NMSF.

\section{Other material}

CABO VERDE • 1 spec., $22.3 \mathrm{~mm}$; Boa Vista Island, Derrubado (bay East); 16 $13^{\prime} 33^{\prime \prime} \mathrm{N}, 2^{\circ} 47^{\prime} 3^{\prime \prime} \mathrm{W}$; 1 Jul. 2013; MNCN exped.; GenBank mitochondrion, partial genome: MF491557; MNCN 15.05/80407 (Fig. 4E) - 1 spec.; same collection data as for preceding; GenBank mitochondrion, partial genome: MF491558; MNCN 15.05/80408 • 1 spec.; Boa Vista Island, Ponta Antónia; 16²13'24" N, 2246'59" W; 1 Jul. 2013; MNCN exped.; GenBank mitochondrion, partial genome: MF491559; MNCN 15.05/80408 - 1 spec.; Boa Vista Island, Morro de Areia; 16 ${ }^{\circ} 5^{\prime 2} 4^{\prime \prime}$ N, 22 $2^{\circ} 7^{\prime} 7^{\prime \prime}$ W; 21 Apr. 2015; MNCN exped.; GenBank mitochondrion, partial genome: MF491592; MNCN 15.05/79947 • 1 spec.; Maio Island, Porto Cais; 15 $19^{\prime} 15^{\prime \prime} \mathrm{N}, 2^{\circ} 11^{\prime} 10^{\prime \prime} \mathrm{W}$; 31 Mar. 2013; MNCN exped.; GenBank mitochondrion, partial genome: MF491524; MNCN 15.05/78695 • 1 spec., 24.5 mm, holotype of Africonus cristinapessoae; Boa Vista Island, Varandinha; MMM • $1 \mathrm{spec} ., 17.8 \mathrm{~mm}$, holotype of Africonus gallopalvoi; Boa Vista Island, Varandinha; MMM $\bullet 1$ spec., $25 \mathrm{~mm}$, holotype of Africonus tarafensis; Boa Vista Island, Baixa de Padaroso; MMM.

\section{Geographical distribution}

Multiple localities around Boa Vista Island and north Maio Island (Baía do Navío Quebrado and Praia Real), Cabo Verde Archipelago.

\section{Conservation status in IUCN Red List}

Least concern.

\section{Remarks}

Africonus fuscoflavus is the most senior name applicable to a clade composed of individuals from a number of populations of cones distributed around Boa Vista and north Maio Island. Most of these populations had been introduced as separate species based upon their distinctive shell patterns. All of them share the same elongated radular tooth morphology observed in A. fuscoflavus (Abalde et al. 2017a). Representative

Fig. 4 (opposite page). A. Conus felitae Rolán, 1990, holotype, $12.7 \mathrm{~mm}$ (MNCN 15.05/1099). B. Africonus fernandesi (Tenorio, Afonso \& Rolán, 2008), $14.5 \mathrm{~mm}$ (MNCN 15.05/78598). C. Africonus freitasi Tenorio, Afonso, Rolán, Pires, Vasconcelos, Abalde \& Zardoya, 2018, holotype, $13.7 \mathrm{~mm}$ (MNCN 15.05/200008) D. Conus verdensis furnae Rolán, 1990, holotype, 21.1 mm (MNCN 15.05/1097). E. Africonus fuscoflavus (Röckel, Rolán \& Monteiro, 1980), $22.3 \mathrm{~mm}$ (MNCN 15.05/80407). F. Conus damottai galeao Rolán, 1990, holotype, 21.3 mm (MNCN 15.05/1093). G. Africonus gonsaloi Afonso \& Tenorio, 2014, holotype, 19.3 mm (MNCN 15.05/60119). H. Africonus grahami (Röckel, Cosel \& Burnay, 1980), 24.0 mm (MNCN 15.05/78549). I. Conus infinitus Rolán, 1990, holotype, $20.8 \mathrm{~mm}$ (MNCN, 15.05/1095). J. Conus isabelarum Tenorio \& Afonso, 2004, holotype, $22.8 \mathrm{~mm}$ (MNCN 15.05/46654). K. Conus josephinae Rolán, 1980, holotype, $25.8 \mathrm{~mm}$ (MNCN 15.05/1050). L. Africonus kersteni (Tenorio, Afonso \& Rolán, 2008), holotype, $20.8 \mathrm{~mm}$ (MNCN 15.05/47051). M. Africonus longilineus (Röckel, Rolán \& Monteiro, 1980), 21.7 mm (MNCN 15.05/79738). N. Africonus lugubris (Reeve, 1849), 14.5 mm (MNCN 15.05/90431). O. Africonus maioensis (Trovão, Rolán \& Félix-Alves, 1990), 29.5 mm (MNCN 15.05/78689). P. Africonus miruchae (Röckel, Rolán \& Monteiro, 1980), 12.9 mm $(\mathrm{MNCN} 15.05 / 79789)$. Scale bars $=10 \mathrm{~mm}$. 


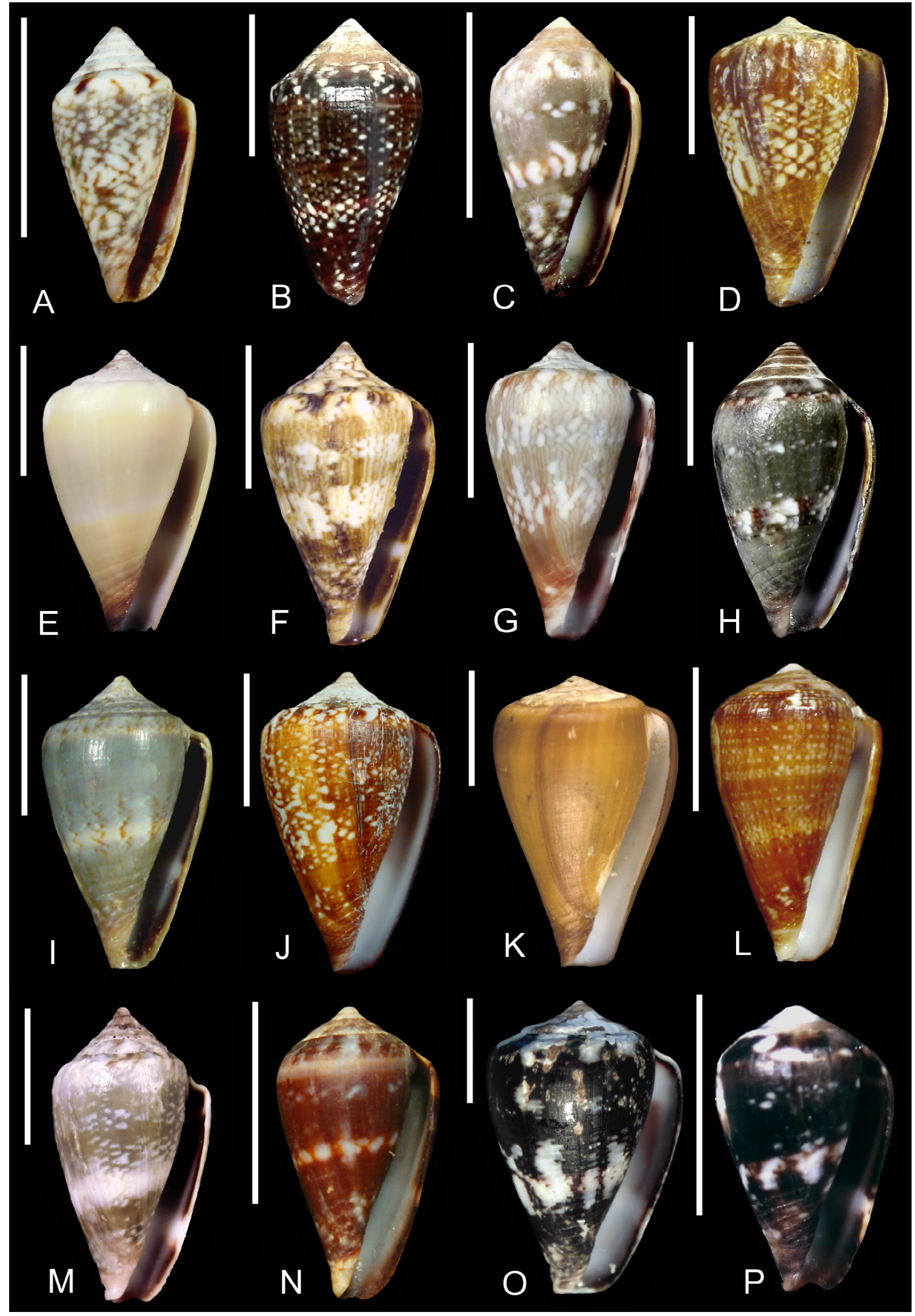


specimens of these taxa examined molecularly exhibit mitogenome sequences with little divergences with respect to that of $A$. fuscoflavus, and can be considered conspecific. Additionally, the type material of both A. cristinapessoae and A. gallopalvoi is consistent with the taxon A. fuscoflavus bearing a characteristic pattern of very fine brown axial lines. The recently described $A$. tarafensis was compared by the authors to A. delanoyae, which has similar shell pattern. However, the shell profile is even more consistent with that of A. fuscoflavus. We therefore consider A. tarafensis as another patterned form of A. fuscoflavus, morphologically similar to the population from Ponta Antónia (very close to Baía do Tarafe, in Derrubado area) included in our phylogeny, and initially identified $A$. cf. delanoyae (Abalde et al. 2017a). We can conclude that $A$. fuscoflavus is another example of a polymorphic species, comprising several well-defined forms with characteristic shell patterns, sharing the same radular morphology and mitogenome sequence. The distribution range for this species is now expanded and includes the islands of Boa Vista and Maio.

\section{Africonus galeao (Rolán, 1990)}

Fig. 4F

Conus damottai galeao Rolán, 1990: 36, pl. 1, fig. 13.

Conus claudiae Tenorio \& Afonso, 2004: 27, pl. 3.

Conus damottai galeao - Monteiro et al. 2004: 37, pls 90-93.

\section{Material examined}

Holotype

CABO VERDE • 21.3 mm; Maio Island, Baía do Navío Quebrado; E. Rolán leg.; MNCN 15.05/1093 (Fig. 4F).

\section{Other material}

CABO VERDE - 1 spec.; Maio Island, Baía do Navío Quebrado, Terras Salgadas; $15^{\circ} 18^{\prime} 54^{\prime \prime}$ N, 2311'2" W; 30 Mar. 2013; MNCN exped.; GenBank mitochondrion, partial genome: MF491522;

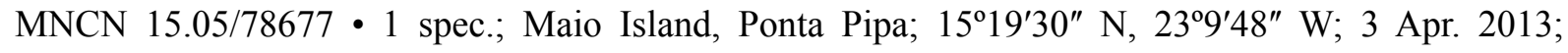
MNCN exped.; GenBank mitochondrion, partial genome: MF491536; MNCN 15.05/78832 • 1 spec.; same collection data as for preceding; GenBank mitochondrion, partial genome: MF491537; MNCN $15.05 / 78848$.

\section{Geographical distribution}

North Maio Island (Baía do Navío Quebrado to Baía de Galeão), Cabo Verde Archipelago.

\section{Conservation status in IUCN Red List}

Least concern.

\section{Remarks}

This taxon was initially introduced as a subspecies of $A$. damottai distributed in Maio Island. There are clear morphological similarities in shell pattern and radular tooth. However, the phylogenetic analysis indicates that $A$. galeao is actually a separate species, whose lineage diverged from that of $A$. damottai in the middle Pliocene. It is sister to $A$. calhetae, a parapatric valid species from Maio Island, which had been also initially introduced as a subspecies of $A$. navarroi. There is a number of morphs of A. galeao with distinctive shell patterns (i.e., reticulated, greenish, etc.) corresponding to well-defined populations from different bays in northern Maio Island, but all these have shown to be conspecific. Among these, A. claudiae from Praia Real is a color form of A. galeao. This must not be confused with another color 
variation of $A$. calhetae found in the west coast of Maio Island, which also resembles phenotypically the A. galeao form claudiae.

Africonus gonsaloi Afonso \& Tenorio, 2014

Fig. $4 \mathrm{G}$

Africonus gonsaloi Afonso \& Tenorio, 2014: 51, pl. 2, figs 1-8

Material examined

Holotype

CABO VERDE • 19.3 mm; Maio Island, Praia Gonçalo; M.J. Tenorio leg.; MNCN 15.05/60119 (Fig. 4G).

\section{Other material}

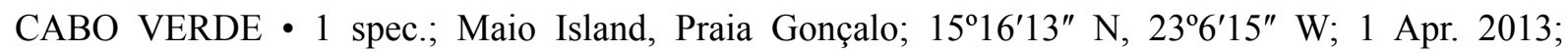
MNCN exped.; GenBank mitochondrion, partial genome: MF491528; MNCN 15.05/78759 • 1 spec.; same collection data as for preceding; GenBank mitochondrion, partial genome: MF491529; MNCN 15.05/78760.

\section{Geographical distribution}

Only known from the type locality, Maio Island, Cabo Verde Archipelago.

\section{Conservation status in IUCN Red List}

Not evaluated.

\section{Remarks}

This was the first endemic species described from the northeast coast of Maio Island. It is sister to A. raulsilvai, an allopatric, closely related species widely distributed along the east and north coasts of Maio Island. Both, A. raulsilvai and A. gonsaloi are members of a clade sister to A. verdensis, the only endemic species from the neighboring Santiago Island.

\section{Africonus grahami (Röckel, Cosel \& Burnay, 1980)}

Fig. $4 \mathrm{H}$

Conus grahami Röckel, Cosel \& Burnay, 1980b: 130, figs 1-10.

Conus grahami pseudoventricosus (not C. mediterraneus var. pseudoventricosa Sacco, 1893) Röckel et al., 1980a: 83, fig. 54 .

Conus grahami luziensis Rolán et al., 1983: 17 (nom. nov. for C. grahami pseudoventricosus).

Conus grahami grahami - Monteiro et al. 2004: 49, pl. 122.

Conus grahami luziensis - Monteiro et al. 2004: 49, pl. 124, figs 5, 7.

\section{Material examined}

\section{Holotype}

CABO VERDE • 24 mm; São Vicente Island; NMSF.

\section{Other material}

CABO VERDE • 1 spec., 24.0 mm; São Vicente Island, Calhau; 1651'7" N, 2451'59" W; 12 Apr. 2016; MNCN exped.; MNCN 15.05/78552 (Fig 4H) 1 spec.; same collection data as for preceding; GenBank mitochondrion, partial genome: MF491599; MNCN 15.05/78552. 


\section{Geographical distribution}

Eastern side of São Vicente and southeastern extremity off the neighboring island of Santa Luzia at Praia Francisca, Cabo Verde Archipelago.

\section{Conservation status in IUCN Red List}

Least concern.

\section{Remarks}

The elongated-ovate aspect of the shell, its greenish color and typical pattern, as well as the high spire and convex profile easily separate $A$. grahami from most other species from the Cabo Verde Archipelago, with the exception of $A$. longilineus from Sal Island, which was in fact described initially as a subspecies of A. grahami. However, A. longilineus and A. grahami are two separate species, only distantly related according to the phylogeny. Thus, the similarities in shell morphology are most likely due to convergence. The name A. grahami luziensis (initially introduced as Conus grahami pseudoventricosus Röckel, Rolán \& Monteiro, 1980, and then renamed due to homonymy with Conus mediterraneus var. pseudoventricosa Sacco, 1893, a fossil) was applied to populations of $A$. grahami from the island of Santa Luzia. We have not been able to examine molecularly specimens from this population. However, given the lack of clear morphological features separating the populations from São Vicente and Santa Luzia, and the past connectivity between these two islands, we hereby consider $A$. grahami luziensis as a synonym (form) of $A$. grahami. The species sister to $A$. grahami according to the phylogeny is A. decoratus, which however exhibits very distinct shell morphology.

Africonus infinitus (Rolán, 1990)

Fig. 4I

Conus infinitus Rolán, 1990: 39, pl. 1, fig. 12.

Conus infinitus - Monteiro et al. 2004: 53, pl. 114.

\section{Material examined}

\section{Holotype}

CABO VERDE • 20.8 mm; Maio Island, Baía de Pau Seco; 1-2 m depth; E. Rolán leg.; MNCN 15.05/1095 (Fig. 4I).

\section{Other material}

CABO VERDE • 1 spec.; Maio Island, Ponta de Pau Seco; 1515'26" N, 2313'17" W; 29 Mar. 2013; MNCN exped.; GenBank mitochondrion, partial genome: KY864967; MNCN 15.05/78650.

\section{Geographical distribution}

Maio Island, Cabo Verde Archipelago.

\section{Conservation status in IUCN Red List}

Least concern.

\section{Remarks}

This is a species widely distributed around Maio Island, very especially along the east and north coasts. It is sister to A. roeckeli from Boa Vista Island, and only distantly related to other species with similarities in shell morphology such as $A$. antoniomonteiroi from Sal Island. 
TENORIO M.J. et al., Taxonomic revision of West African cone snails

\section{Africonus insulae sp. nov. urn:1sid:zoobank.org:act:97702746-A650-4A17-AAEE-4D914E1026F5}

Fig. 5A-J

Conus curralensis (not C. curralensis Rolán, 1986) - Monteiro et al. 2004: pl. 87, figs 1-9. Africonus curralensis (not C. curralensis Rolán, 1986) - Abalde et al. 2017a: not figured. Africonus curralensis (not C. curralensis Rolán, 1986) - Monnier et al. 2018: 1143, figs 2-3, 5.

\section{Etymology}

The name insulae means 'of the island', in reference to the type locality of the deserted island of Santa Luzia.

\section{Material examined}

Holotype

CABO VERDE • 23.9 mm; Santa Luzia Island, Praia de Palmo Tostão; $16^{\circ} 45^{\prime} 19^{\prime \prime}$ N, 244ㄴ $45^{\prime 2} 4^{\prime \prime}$ W; 14 Apr. 2016; MNCN exped.; GenBank mitochondrion, partial genome: MF491602; MNCN 15.05/78581 (Fig. 5A-B)

\section{Paratypes}

CABO VERDE 1 spec., $20.0 \mathrm{~mm}$; same collection data as for holotype; MNCN 15.05/78585 (Fig. 5C, paratype 1) - 1 spec., 18.8 mm; Santa Luzia Island, Curral; 16 $46^{\prime} 23^{\prime \prime}$ N, 24²47'13" W; 14 Apr. 2016; MNCN exped.; MNHN IM-2000-35016 (Fig. 5D, paratype 2) • 1 spec., $24.1 \mathrm{~mm}$; same collection data as for preceding; MNCN 15.05/78579 (Fig. 5F, paratype 4) 11 spec., $19.1 \mathrm{~mm}$; same collection data as for preceding; MNCN 15.05/78590 (Fig. 5G, paratype 5) 1 spec., $16.2 \mathrm{~mm}$; same collection data as for holotype; MNCN 15.05/78586 (Fig. 5E, paratype 3) $11 \mathrm{spec}$., $23.0 \mathrm{~mm}$; same collection data as for holotype; MNCN 15.05/78582 (Fig. 5H, paratype 6) 11 spec., $22.6 \mathrm{~mm}$; same collection data as for holotype; MNCN 15.05/78584 (Fig. 5I, paratype 7) $11 \mathrm{spec}$., $24.9 \mathrm{~mm}$; same collection data as for holotype; UCV 2019/00015 (Fig. 5J, paratype 8).

\section{Other material}

CABO VERDE $\bullet 5$ specs; same collection data as for holotype; MJT $\bullet 1$ spec., $4 \mathrm{~mm}$; Santa Luzia Island, Curral; 16² $46^{\prime 2} 23^{\prime \prime}$ N, 244ㄱ'13" W; 14 Apr. 2016; MNCN exped.; MJT.

\section{Description}

Morphometric parameters. $\mathrm{S}_{\mathrm{L}}=16-30 \mathrm{~mm}\left(\right.$ mean $\left.\mathrm{S}_{\mathrm{L}}=22 \mathrm{~mm}\right) ; \mathrm{RD}=0.68-0.76 ; \mathrm{RSH}=0.11-0.19$; $\mathrm{PMD}=0.78-0.86$.

SHELL. Moderately small to small. Maximum length: $30.6 \mathrm{~mm}$. Shell profile broadly and ventricosely conical to broadly conical, with convex sides adapically, and straight below. Spire of moderate height, of straight to concave outline. Protoconch not observed due to erosion, but assumed paucispiral. Teleoconch whorls flat or slightly concave, with 3-4 spiral cords becoming rather obsolete in late whorls. Shoulder angulate. Early teleoconch whorls white. Suture of spire whorls pigmented with dark brown. Late teleoconch whorls yellow to light brown with radial white irregular blotches. Ground color yellow to light brown. Last whorl overlaid in variable amount with oblique white lines forming zigzag pattern. Small white spots and axial flecks arranged in spiral band frequently present. Columella white to light purple. Aperture white and porcellanous inside, with pale purple to light brown diffuse area near the outer lip crossed by two narrow bands of a lighter color. Periostracum yellow-brown, thin and translucent. 

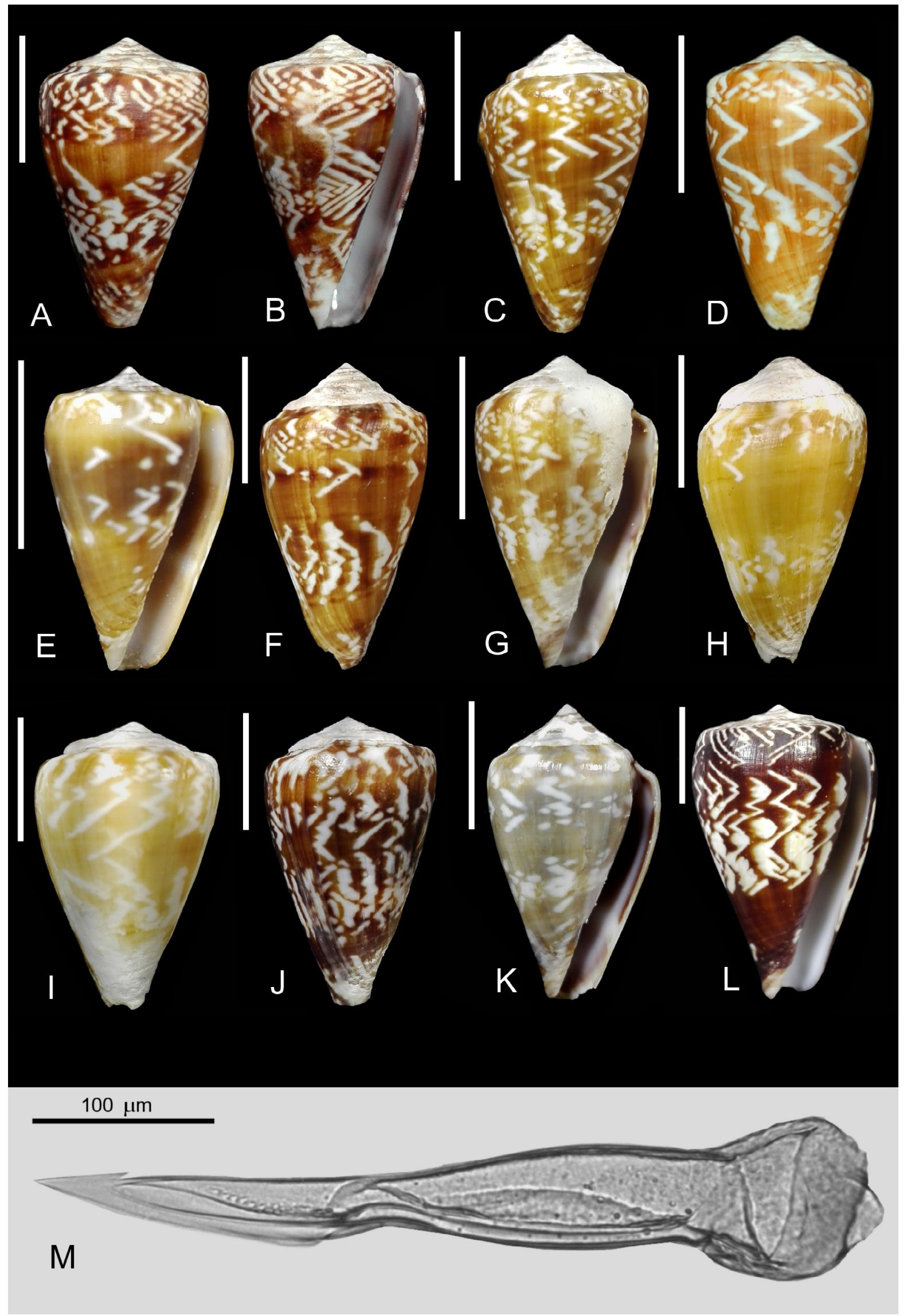
RADULAR TEETH. Radula studied from two specimens. 27-35 teeth in radular sac. Radular tooth of medium relative size $\left(S_{L} / T_{L}=50-65\right)$, with well-developed apical barb. Anterior section shorter than posterior section of tooth $\left(\mathrm{T}_{\mathrm{L}} / \mathrm{AP}_{\mathrm{L}}=2.4-2.6\right)$. Waist evident. Blade rounded, covering most of anterior section $\left(100 \mathrm{~B}_{\mathrm{L}} / \mathrm{AP}_{\mathrm{L}}=83-87 \%\right)$. Serration with 10-15 denticles, which do not reach apical portion, arranged in one row ending in small terminating cusp. Base rounded, with small spur (Fig. 4M).

\section{Distribution and habitat}

Southwest coast of Santa Luzia Island (Curral and Praia de Palmo Tostão), Cabo Verde Archipelago. On rocks and under stones, in 2 to $5 \mathrm{~m}$ depth.

\section{Conservation status in IUCN Red List}

Not evaluated.

\section{Remarks}

This species was previously confused with $A$. curralensis, which lives sympatrically on Santa Luzia Island. In fact, the specimen identified as A. curralensis in Abalde et al. (2017a) actually corresponds to the taxon A. insulae sp. nov. Molecular examination of a specimen (Fig. 5K) morphologically perfectly matching the holotype of $A$. curralensis (Fig. $3 \mathrm{~J}$ ) showed a genetic divergence consistent with the separation at the species level. Hence, $A$. curralensis and A. insulae sp. nov. are two closely related sister species living in sympatry. Both species essentially have the same shell shape and almost identical radular teeth morphologies (Fig. 4M). However, they can easily be separated by differences in shell pattern. The ground color in A. curralensis is composed of different shades of olive green with two narrow spiral bands of a lighter color, whereas in $A$. insulae sp. nov. the ground color is plain yellow to light brown. The pattern in A. curralensis consists of irregularly shaped white flecks and blotches, whereas in $A$. insulae sp. nov. it is better defined, composed of fine white zigzag lines and small arrow head-shaped markings. This pattern of zigzag lines on the shell also resembles that present in certain forms of $A$. decoratus. This species however has a much darker ground color, usually dark brown to black, a white-colored aperture, and is phylogenetically divergent. The shell of the recently described A. santaluziensis Cossignani \& Fiadeiro, 2015 (hereby considered as provisionally valid) has a similar ground color, but it is very sparsely patterned and with a white-colored aperture. Besides, the shell of this species has rounded shoulders and a more ventricose appearance, instead of conical.

Africonus isabelarum (Tenorio \& Afonso, 2004)

Fig. 4J

Africonus isabelarum Tenorio \& Afonso, 2004: 29, pl. 4.

Conus decoratus (not decoratus Rolán, Röckel \& Monteiro, 1980) - Monteiro et al. 2004: pl. 120, fig. 3. Conus decoratus form C (not C. decoratus Rolán, Röckel \& Monteiro, 1980) - Röckel et al. 1980a: pl. 63 , fig. 30,3 .

Fig. 5 (opposite page). A-J, M. Africonus insulae sp. nov. A-B. Holotype (dorsal and ventral views), $23.9 \mathrm{~mm}$ (MNCN 15.05/78581). C. Paratype 1, $20.0 \mathrm{~mm}$ (MNCN 15.05/78585). D. Paratype 2, $18.8 \mathrm{~mm}$ (MNHN IM-2000-35016). E. Paratype 3, $16.2 \mathrm{~mm}$ (MNCN 15.05/78586). F. Paratype 4, $24.1 \mathrm{~mm}$ (MNCN 15.05/78579). G. Paratype 5, 19.1mm (MNCN 15.05/78590). H. Paratype 6, $23.0 \mathrm{~mm}$ (MNCN 15.05/78582). I. Paratype 7, $22.6 \mathrm{~mm}$ (MNCN 15.05/78584). J. Paratype 8, 24.9 mm (UCV 2019/00015). K. Africonus curralensis (Rolán, 1986), 23.0 mm (MNCN 15.05/78591). L. Africonus decoratus (Röckel, Rolán \& Monteiro, 1980), 30.5 mm (MNCN 15.05/78578). M. Radular tooth, Africonus insulae sp. nov., Curral, Santa Luzia Island, Cabo Verde (MJT), $\mathrm{S}_{\mathrm{L}}=29.2 \mathrm{~mm}$. Scale bars $=10 \mathrm{~mm}$ unless otherwise indicated. 


\section{Material examined}

Holotype

CABO VERDE • 22.8 mm; Maio Island, Baía de Pau Seco; C.M.L. Afonso leg.; MNCN 15.05/46654 (Fig. 4J).

\section{Other material}

CABO VERDE • 1 spec.; Maio Island, Ponta de Pau Seco; 1515'26" N, 231'17" W; 29 Mar. 2013; MNCN exped.; GenBank mitochondrion, partial genome: MF491538; MNCN 15.05/78850.

\section{Geographical distribution}

West and northwest of Maio Island, Cabo Verde Archipelago.

\section{Conservation status in IUCN Red List}

Least concern.

\section{Remarks}

Africonus isabelarum, endemic to Maio Island, was initially considered conspecific with A. decoratus from São Vicente and Santa Luzia, due to similarities in shell pattern (A. decoratus form C in Röckel et al. 1980a). In the phylogeny, it stands alone, sister to a large clade comprising many species distributed in Boa Vista and Maio islands, and only distantly related to $A$. decoratus.

\section{Africonus josephinae (Rolán, 1980)}

Fig. 4K

Conus josephinae Rolán, 1980: 80. pls 1, 3, fig. 104.

Africonus marckeppensi Cossignani \& Fiadeiro, 2017b: 33.

Africonus guiandradoi Cossignani \& Fiadeiro, 2017c: 52. syn. nov.

Africonus demisgeraldoi Cossignani \& Fiadeiro, 2018a: 17. syn. nov.

Conus josephinae - Monteiro et al. 2004: 54, pls 109, 111.

\section{Material examined}

\section{Holotype}

CABO VERDE • 25.8 mm; Boa Vista Island, Sal Rei; 1-5 m depth; E. Rolán leg.; MNCN 15.05/1050 (Fig. 4K).

\section{Other material}

CABO VERDE • 1 spec.; Boa Vista Island, Ilhéu de Sal Rei; 16 ${ }^{\circ} 9^{\prime 50}$ " N, 2255'31" W; 3 Jul. 2013; MNCN exped.; GenBank mitochondrion, partial genome: MF491565; MNCN 15.05/80415 - 1 spec.; Boa Vista

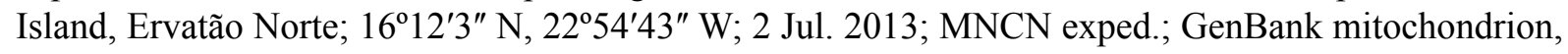
partial genome: MF491562; MNCN 15.05/80412 1 spec., $25 \mathrm{~mm}$, holotype of Africonus guiandradoi; Boa Vista Island, NE of Sal Rei in Baixa da Hortinha; MMM • 1 spec., $23.8 \mathrm{~mm}$, holotype of Africonus demisgeraldoi; Boa Vista Island, Baixa de Padaroso; MMM.

\section{Geographical distribution}

Multiple localities around Boa Vista Island, Cabo Verde Archipelago.

\section{Conservation status in IUCN Red List}

Near threatened. Status revision required. 


\section{Remarks}

This species is very closely related to $A$. borgesi. With regards to the conservation status, $A$. josephinae used to be abundant around its type locality in Boa Vista Island. However, the expansion of the town of Sal Rei due to touristic and industrial development is seriously compromising the habitat of this population. The alleged conspecific population from Maio Island has been now established as a separate species, namely $A$. perrineae Cossignani \& Fiadeiro, 2018, in agreement with molecular data (Abalde et al. 2017a; Tenorio et al. 2018). This significantly reduces the distribution range of $A$. josephinae. On the other hand, several populations distributed around Boa Vista Island, which have been recently introduced as new species, actually correspond to different color and pattern variations of $A$. josephinae. These names are here synonymized accordingly. Thus, A. guiandradoi is applied to pale-colored individuals of $A$. josephinae with a pattern of sparse fine brown spiral lines. This pattern is commonly observed in specimens of $A$. perrineae from Maio Island, but it is rare in Boa Vista. The name $A$. demisgeraldo $i$ applies to typical brown specimens of $A$. josephinae that display one midbody band irregularly patterned with white blotches. The alleged differences in shell shape were not statistically tested, and the presence of white blotches on the shell does not warrant the separation from $A$. josephinae. Taking into consideration all these changes, a risk status revision for $A$. josephinae is strongly recommended.

\section{Africonus kersteni (Tenorio, Afonso \& Rolán, 2008)}

Fig. 4L

Conus kersteni Tenorio, Afonso \& Rolán, 2008: 2, pl. 1.

Conus cuneolus form L (not cuneolus Reeve, 1843) - Röckel et al. 1980a: 113, pl. 6, row 4, fig. 92.

\section{Material examined}

Holotype

CABO VERDE • 20.8 mm; São Nicolau Island, Tarrafal; 16 $33^{\prime} 54^{\prime \prime}$ N, 2421'35" W; E. Rolán leg.; MNCN 15.05/47051 (Fig. 4L)

\section{Geographical distribution}

Southwest coast of São Nicolau Island, Cabo Verde Archipelago.

\section{Conservation status in IUCN Red List}

Near threatened.

\section{Remarks}

Prior to its introduction as a full species, it was referred to as Conus cuneolus form L in Röckel et al. (1980a). This species has not been examined molecularly. However, the geographic isolation of São Nicolau Island within the Cabo Verde Archipelago together with the distinct morphology of the shell and radula suggest that this is most likely a valid species, not closely related to $A$. cuneolus.

Africonus longilineus (Röckel, Rolán \& Monteiro, 1980)

Fig. 4M

Conus grahami longilineus Röckel, Rolán \& Monteiro, 1980: 85, figs 56-57.

Conus melissae Tenorio, Afonso \& Rolán, 2008: 8, pl. 3

Africonus cagarralensis Cossignani, 2014: 21.

Africonus nelsonandradoi Cossignani \& Fiadeiro, 2015a: 18. syn. nov. 
Africonus minimus Cossignani \& Fiadeiro, 2015b: 3. syn. nov.

Conus longilineus - Monteiro et al. 2004: 55, pl. 124, figs 4-7.

\section{Material examined}

\section{Holotype}

CABO VERDE $\bullet 16.8 \mathrm{~mm}$; Sal Island; 0.8-2 m depth; NMSF.

\section{Other material}

CABO VERDE • 1 spec.; Sal Island, Serra Negra; 16 $6^{\circ} 38^{\prime} 17^{\prime \prime}$ N, 22 $2^{\circ} 53^{\prime} 56^{\prime \prime}$ W; 5 Apr. 2014; MNCN exped.; GenBank mitochondrion, partial genome: MF491572; MNCN 15.05/79739 • 1 spec., 21.7 mm; same collection data as for preceding; MNCN 15.05/79738 (Fig. 4M) • 1 spec.; Sal Island, Pedra Lume; $16^{\circ} 45^{\prime} 44^{\prime \prime} \mathrm{N}, 22^{\circ} 53^{\prime} 2^{\prime \prime} \mathrm{W} ; 7$ Apr. 2014; MNCN exped.; GenBank mitochondrion, partial genome: MF491579; MNCN 15.05/79804 • 1 spec.; Sal Island, Baía da Parda; 16²45'7" N, 2253'56" W; 6 Apr. 2014; MNCN exped.; GenBank mitochondrion, partial genome: MF491577; MNCN 15.05/79779 • 1 spec., $14.0 \mathrm{~mm}$, holotype of Africonus nelsonandradoi; Sal Island, area of Calhetinha; $0.3-3 \mathrm{~m}$ depth; MMM • 1 spec., $7.2 \mathrm{~mm}$, holotype of Africonus minimus; Sal Island, Praia do Monte Grande and Ponta do Linguincho; MMM.

\section{Geographical distribution}

East coast, Sal Island, Cabo Verde Archipelago.

\section{Conservation status in IUCN Red List}

Least concern.

\section{Remarks}

This taxon was initially introduced as a subspecies of $A$. grahami. Despite superficial resemblance in shell morphology, A. longilineus is a separate species endemic to Sal Island, only distantly related to A. grahami. Although the type locality for A. longilineus was not specifically mentioned in the original description, its distribution range was stated to be along the east coast of Sal Island, with another population in the north of the island. Several representative specimens of recently named taxa described from the east coast of Sal Island exhibit mitogenome sequences almost identical to that of $A$. longilineus, and are therefore considered synonyms (forms) of this species. The species A. nelsonandradoi was compared in the original description to the very variable $A$. cagarralensis, which is a synonym (form) of A. longilineus (Abalde et al. 2017a). We propose to consider that $A$. nelsonandradoi represents merely a northern population of the latter. On the other hand, A. minimus likely is a juvenile of A. longilineus. Besides, the name Africonus minimus Cossignani \& Fiadeiro, 2015b most likely is invalid under ICZN articles 57.3 and 59.1, as it is a junior secondary homonym of Conus minimus Linnaeus, 1758, Conus minimus Hwass in Bruguière, 1792 and Conus minimus d'Archiac, 1843.

Africonus lugubris (Reeve, 1849)

Fig. $4 \mathrm{~N}$

Conus lugubris Reeve, 1849: pl. IX, sp. 279.

Conus fuscus Barros e Cunha, 1933: 194.

Conus lugubris - Monteiro et al. 2004: 56, pl. 126, figs 6-7. 


\section{Material examined}

\section{Lectotype}

Lectotype in NHMUK 1981056. Type locality: not known. Hereby designated as north São Vicente Island, Cabo Verde Archipelago.

\section{Other material}

CABO VERDE • 1 spec., 14.5 mm; São Vicente Island, Matiota; E. Rolán leg.; MNCN 15.05/90431 (Fig. 4N).

\section{Geographical distribution}

Matiota, north São Vicente, Cabo Verde Archipelago.

\section{Conservation status in IUCN Red List}

Critically endangered.

\section{Remarks}

This species has not been examined molecularly. Specimens matching the type material of this species were found in the 1970's and 1980's in Matiota beach in São Vicente Island, but this is now part of a large and touristic urban area in the vicinity of the modern Port of Mindelo. This population is believed to be now extinct. We are not aware of live specimens of this species having been observed for over 20 years. Some empty shells of this species have been collected in recent years, and the search for live specimens in new locations along the north coast of São Vicente Island continues, without success for the moment being. It is feared that the species might have become extinct. The claim for specimens of A. cf. lugubris found at Calhau and Saragaça to the east of São Vicente Island most likely corresponds to individuals of $A$. freitasi.

\section{Africonus maioensis (Trovão, Rolán \& Félix-Alves, 1990)}

Fig. $4 \mathrm{O}$

Conus maioensis Trovão, Rolán \& Félix-Alves, 1990: 71, fig. 11.

Conus crioulus Tenorio \& Afonso, 2004: 30, pl. 5.

Africonus zinhoi Cossignani, 2014: 19.

Africonus marcocastellazzii Cossignani \& Fiadeiro, 2014a: 14.

Africonus cossignanii Cossignani \& Fiadeiro, 2014a: 18. syn. nov.

Africonus decolrobertoi Cossignani \& Fiadeiro, 2017a: 28. syn. nov.

Conus maioensis - Monteiro et al. 2004: 57, pl. 115.

Conus irregularis (not irregularis G.B. Sowerby II, 1858) - Monteiro et al. 2004: pl. 103, figs 1, 4, 6-7.

\section{Material examined}

The holotype was in Museu Bocage in Lisbon and currently assumed to be lost due to a fire which destroyed the building of the hosting institution. A neotype was subsequently designated (Monteiro et al. 2014).

\section{Neotype}

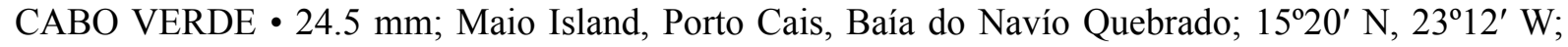
MNCN 15.05/69910. 


\section{Other material}

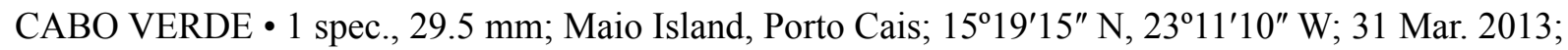
MNCN exped.; GenBank mitochondrion, partial genome: MF491523; MNCN 15.05/78689 (Fig. 4O) - 1 spec.; Maio Island, Lage Branca; 31 Mar. 2013; MNCN exped.; GenBank mitochondrion, partial genome: MF491527; MNCN 15.05/79727 - 1 spec.; Maio Island, Porto Cais (North); $15^{\circ} 19^{\prime} 45^{\prime \prime} \mathrm{N}$, 2310'57" W; 1 Apr. 2013; MNCN exped.; GenBank mitochondrion, partial genome: MF491530;

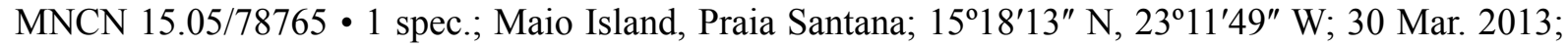
MNCN exped.; GenBank mitochondrion, partial genome: MF491521; MNCN 15.05/78670 • 1 spec.;

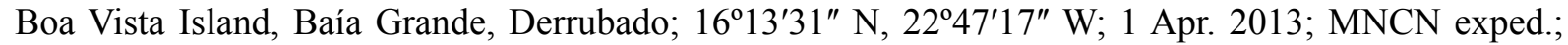
GenBank mitochondrion, partial genome: MF491544; MNCN 15.05/80394 • 1 spec.; Boa Vista Island, Curral Velho; 15 58'4" N, 22 47'42" W; 22 Apr. 2015; MNCN exped.; GenBank mitochondrion, partial genome: MF491595; MNCN 15.05/79979 • 1 spec., 28.5 mm, holotype of Africonus cossignanii; Maio Island, Praia Real; MMM • 1 spec., $13.1 \mathrm{~mm}$, holotype of Africonus decolrobertoi; Maio Island, Praia Real; MMM.

\section{Geographical distribution}

Maio and Boa Vista islands, Cabo Verde Archipelago.

\section{Conservation status in IUCN Red List}

Least concern.

\section{Remarks}

This is one of the most representative species of Maio Island, as reflected by its name. Off Maio Island it is distributed along the north coast, from Baía do Navio Quebrado to Baía do Galeao. Each of the populations has its own characteristic shell pattern on a green to black background color. This variability has led to the introduction of several new taxa names. However, an examination of the mitogenome sequences indicates that all these names correspond to plain color forms of one single polymorphic species, namely $A$. maioensis. Some individuals of the polyphyletic taxon $A$. irregularis also fell within the A. maioensis clade. One of them was from the population from Porto Cais, on Maio Island, and the other from Baia Grande de Derrubado, Boa Vista Island. Once that we have designated the lectotype for the taxon Conus irregularis G.B. Sowerby II, 1858 and its type locality as "Estancinha, north of Sal Rei, Boa Vista Island", and established that this is a synonym (form) of A. crotchii (see above), it becomes clear that the irregularis-like specimen from Boa Vista in the maioensis clade is not conspecific with A. irregularis ( $=$ A. crotchii), but with $A$. maioensis. This indicates that the distribution range of A. maioensis is not restricted to Maio Island, as it expands to Boa Vista Island. Furthermore, the recently described species $A$. zinhoi from south Boa Vista Island also fell within the A. maioensis clade, and it is therefore another synonym (form) of $A$. maioensis. The holotype of $A$. cossignanii is virtually identical to $A$. crioulus, a form of $A$. maioensis. The alleged differences in shell length and spire profile were not tested, and the minimal differences in shell pattern do not justify a separation at the species level. The recently described $A$. decolroberto $i$ is likely a juvenile of the population of $A$. maioensis from Praia Real, north Maio (which had previously been introduced as a separate species named A. marcocastellazzii). This population is characterized by a predominance of greenish shades on the shell pattern. Other than that, it is merely another morph of $A$. maioensis.

Africonus miruchae (Röckel, Rolán \& Monteiro, 1980)

Fig. 4P

Conus miruchae Röckel et al., 1980a: 89, figs 62-65. 
Conus miruchae - Monteiro et al. 2004: 60, pl. 126, figs 1-5.

Conus longilineus (not C. grahami longilineus Röckel, Rolán \& Monteiro, 1980) - Monteiro et al. 2004: pl. 125.

\section{Material examined}

\section{Holotype}

CABO VERDE • $11.9 \mathrm{~mm}$; Sal Island, Baiona; NMSF.

\section{Other material}

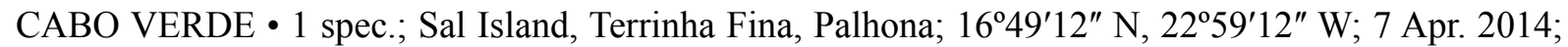
MNCN exped.; GenBank mitochondrion, partial genome: KY864971; MNCN 15.05/79784 • 1 spec.; $12.9 \mathrm{~mm}$; same collection data as for preceding; MNCN 15.05/79789 (Fig. 4P) • 1 spec.; Sal Island, Rabo de Junco; 16 $41^{\prime} 44^{\prime \prime}$ N, 22 ${ }^{\circ} 58^{\prime} 35^{\prime \prime}$ W; 5 Apr. 2014; MNCN exped.; GenBank mitochondrion, partial genome: MF491574; MNCN 15.05/79756.

\section{Geographical distribution}

North of Sal Island, Cabo Verde Archipelago. Also present in Rabo de Junco, on the west coast of Sal Island.

\section{Conservation status in IUCN Red List}

Least concern.

\section{Remarks}

According to the phylogeny, A. miruchae is sister to all the other endemic species from Sal Island. This small-sized species is adapted to the rough sea conditions present in the barren northern coasts of Sal Island. It is often found crawling on the rocky walls of large pools formed during low tide. A population of this species that is present at Rabo de Junco, at the north end of Murdeira Bay, is often confused with A. longilineus due to similarities in shell morphology (Monteiro et al. 2004).

\section{Africonus navarroi (Rolán, 1986)}

Fig. 6A

Conus navarroi Rolán, 1986: 3, fig. 1A.

Conus navarroi navarroi - Monteiro et al. 2004: 63, pl. 98.

\section{Material examined}

\section{Holotype}

CABO VERDE • 16 mm; São Vicente Island, Calhau; E. Rolán leg.; MNCN 15.05/1008 (Fig. 6A).

\section{Other material}

CABO VERDE • 1 spec.; São Vicente Island, Calhau; 16 ${ }^{\circ} 1^{\prime \prime} 7^{\prime \prime}$ N, 2451'59" W; 12 Apr. 2016; MNCN exped.; GenBank mitochondrion, partial genome: MF491600; MNCN 15.05/78557.

\section{Geographical distribution}

Southeast coast São Vicente Island, Cabo Verde Archipelago.

\section{Conservation status in IUCN Red List}

Near threatened. 


\section{Remarks}

This small, distinctive species with a very restricted distribution range belongs to a lineage that includes species endemic to the westernmost islands in the Cabo Verde Archipelago. It is sister to $A$. fernandesi from Santo Antão Island, and to the pair A. curralensis / A. insulae from Santa Luzia. It is only distantly related to $A$. calhetae from Maio Island, which was initially introduced as a subspecies of $A$. navarroi due to similarities in shell morphology, now considered convergent.

Africonus perrineae Cossignani \& Fiadeiro, 2018

Fig. 6B

Africonus perrineae Cossignani \& Fiadeiro, 2018b: 18.

Africonus angeluquei Tenorio, Abalde \& Zardoya, 2018: 79, pl. 2, figs A-M. syn. nov.

Conus sp. - Röckel et al. 1980a: 141, fig. 123, pl. 2, $2^{\text {nd }}$ row, figs c-d.

Conus josephinae (not C. josephinae Rolán, 1980) - Monteiro et al. 2004: pl. 110, figs 1-6.

\section{Material examined}

Holotype

CABO VERDE • 16 mm; Maio Island, Ilhéu da Lage Branca, Praia do Galeão; MMM.

\section{Other material}

CABO VERDE • 1 spec.; $30.0 \mathrm{~mm}$, holotype of A. angeluquei; Maio Island, Lage Branca; $15^{\circ} 18^{\prime} 32^{\prime \prime} \mathrm{N}$, 23ㅇ' $17^{\prime \prime}$ W; 31 Mar. 2013; MNCN exped.; GenBank mitochondrion, partial genome: MF491525; MNCN 15.05/78710 (Fig. 6B).

\section{Geographical distribution}

North of Maio Island, Cabo Verde Archipelago.

\section{Conservation status in IUCN Red List}

Not evaluated.

\section{Remarks}

Mitogenomic analyses revealed that the populations of $A$. josephinae from Boa Vista and the alleged ones from the north of Maio Island actually are not conspecific (Abalde et al. 2017a). This led to the introduction of a new species, which was formally described as $A$. angeluquei based upon shell and radula morphological studies and examination of its mitogenome sequence (Tenorio et al. 2018). However, the name $A$. perrineae was almost simultaneously introduced in a rather succinct description for exactly the same species, and was published one week earlier than $A$. angeluquei, becoming the senior name for this species (Cossignani \& Fiadeiro 2018b). In spite of this, a wealth of useful information about this taxon can be found in the detailed original description of $A$. angeluquei (Tenorio et al. 2018).

\section{Africonus raulsilvai (Rolán, Monteiro \& Fernandes, 1998)}

Fig. 6C

Conus raulsilvai Rolán et al., 1998: 36.

Conus raulsilvai - Monteiro et al. 2004: 69, pl. 118. 
TENORIO M.J. et al., Taxonomic revision of West African cone snails

\section{Material examined}

Holotype

CABO VERDE • 19.7 mm; Maio Island, Baía do Navío Quebrado; MNCN 15.05/27230 (Fig. 6C).

\section{Other material}

CABO VERDE • 1 spec., 30.0 mm; Maio Island, Praia de Soca; 1515'8" N, 2313'4" W; 30 Mar. 2013;

MNCN exped.; GenBank mitochondrion, partial genome: MF491520; MNCN 15.05/78661.

\section{Geographical distribution}

West and north coasts of Maio Island, Cabo Verde Archipelago.

\section{Conservation status in IUCN Red List}

Least concern.

\section{Remarks}

This species is sister to A. gonsaloi, allopatrically distributed on the northeast coast of Maio. Both A. raulsilvai and A. gonsaloi are members of a clade, which is sister to A. verdensis, the only endemic species from the neighboring Santiago Island.

\section{Africonus regonae (Rolán \& Trovão in Rolán, 1990)}

Fig. 6D

Conus regonae Rolán \& Trovão in Rolán, 1990: 31, pl. 1, fig. 3.

Conus cuneolus form I (not C. cuneolus Reeve, 1843) - Röckel et al. 1980a: 109, pl. 5, row 1, fig. 86, row 2.

Conus regonae - Monteiro et al. 2004: 69, pl. 70.

\section{Material examined}

\section{Holotype}

CABO VERDE • 32.7 mm; Sal Island, Palmeira; 2-4 m depth; E. Rolán leg.; MNCN 15.05/1092 (Fig. 6D).

\section{Other material}

CABO VERDE • 1 spec.; Sal Island, Baía da Fontona; 16 $44^{\prime 2} 22^{\prime \prime}$ N, 22 $58^{\prime} 46^{\prime \prime}$ W; 6 Apr. 2014; MNCN exped.; GenBank mitochondrion, partial genome: MF491576; MNCN 15.05/79774 • 1 spec.; Sal Island, Rigona; 16 $6^{\circ} 48^{\prime \prime} 5^{\prime \prime}$ N, 22 $2^{\circ} 59^{\prime} 33^{\prime \prime}$ W; 10 Apr. 2014; MNCN exped.; GenBank mitochondrion, partial genome: MF491585; MNCN 15.05/79858 • 1 spec.; same collection data as for preceding; GenBank mitochondrion, partial genome: MF491584; MNCN 15.05/79853.

\section{Geographical distribution}

West and north Sal Island, Cabo Verde Archipelago.

\section{Conservation status in IUCN Red List}

Vulnerable. 


\section{Remarks}

Prior to its introduction as a full species by Rolán (1990), it was referred to as Conus cuneolus form I in Röckel et al. (1980a). This species is very closely related to A. cuneolus, and lives in sympatry with its form fontonae. It is particularly abundant in rocky areas to the northwest of Sal Island.

Africonus roeckeli (Rolán, 1980)

Fig. $6 \mathrm{E}$

Conus roeckeli Rolán, 1980: 82, pl. 2, fig. 2.

Africonus damioi Cossignani \& Fiadeiro, 2015a: 20.

Conus roeckeli - Monteiro et al. 2004: 70, pl. 95.

\section{Material examined}

Holotype

CABO VERDE • 13.2 mm; Boa Vista Island, Baía das Gatas; E. Rolán leg.; MNCN 15.05/1049 (Fig. 6E).

\section{Other material}

CABO VERDE • 1 spec.; Boa Vista Island, Praia Canto; $16^{\circ} 11^{\prime} 10^{\prime \prime}$ N, $22^{\circ} 42^{\prime} 28^{\prime \prime}$ W; 4 Jul. 2013; MNCN exped.; GenBank mitochondrion, partial genome: MF491567; MNCN 15.05/80417 • 1 spec.; Boa Vista

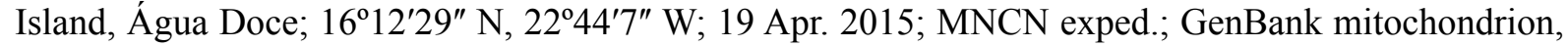
partial genome: MF491586; MNCN 15.05/79886.

\section{Geographical distribution}

North and northeastern Boa Vista Island, Cabo Verde Archipelago.

\section{Conservation status in IUCN Red List}

Least concern.

\section{Remarks}

This is a very variably patterned species from Boa Vista Island. It is sister to A. infinitus from Maio Island, and stands phylogenetically fairly distant from other species in Boa Vista Island. The taxon A. damioi is conspecific, and represents a mere color form of $A$. roeckeli.

Fig. 6 (opposite page). A. Conus navarroi navarroi Rolán, 1986, holotype, 16 mm (MNCN 15.05/1008). B. Africonus angeluquei Tenorio, Abalde \& Zardoya, 2018 (= perrineae Cossignani \& Fiadeiro, 2018), holotype, 30.0 mm (MNCN 15.05/78710). C. Conus raulsilvai Rolán, Monteiro \& Fernandes, 1998, holotype, $19.7 \mathrm{~mm}$ (MNCN 15.05/27230). D. Conus regonae Rolán \& Trovão, 1990, holotype, $32.7 \mathrm{~mm}$ (MNCN 15.05/1092). E. Conus roeckeli Rolán, 1980, holotype, $13.2 \mathrm{~mm}$ (MNCN 15.05/1049). F. Africonus salletae Cossignani, 2014, holotype, $15.5 \mathrm{~mm}$ (MMM). G. Africonus santaluziensis Cossignani \& Fiadeiro, 2015, paratype, $28.1 \mathrm{~mm}$ (Paul Kersten coll.). H. Africonus santanaensis Afonso \& Tenorio, 2014, holotype, $17.1 \mathrm{~mm}$ (MNCN 15.05/60118). I. Conus saragasae Rolán, 1986, holotype, 21.8 mm (MNCN 15.05/1009). J. Africonus verdensis (Trovão, 1979), 22.5 mm (MNCN 15.05/78864). K. Conus vulcanus Tenorio \& Afonso, 2004, holotype, $25.2 \mathrm{~mm}$ (MNCN 15.05/46652). L. Chelyconus ermineus (Born, 1778), $54.3 \mathrm{~mm}$ (MNCN 15.05/80014). M. Genuanoconus genuanus (Linnaeus, 1758), $50.2 \mathrm{~mm}$ (MNCN 15.05/78547). N. Kalloconus ateralbus (Kiener, 1850), $40.1 \mathrm{~mm}$ (MNCN 15.05/79649). O. Kalloconus byssinus (Röding, 1798), $56.4 \mathrm{~mm}$ (MNCN 15.05/90429). Scale bars $=10 \mathrm{~mm}$. 


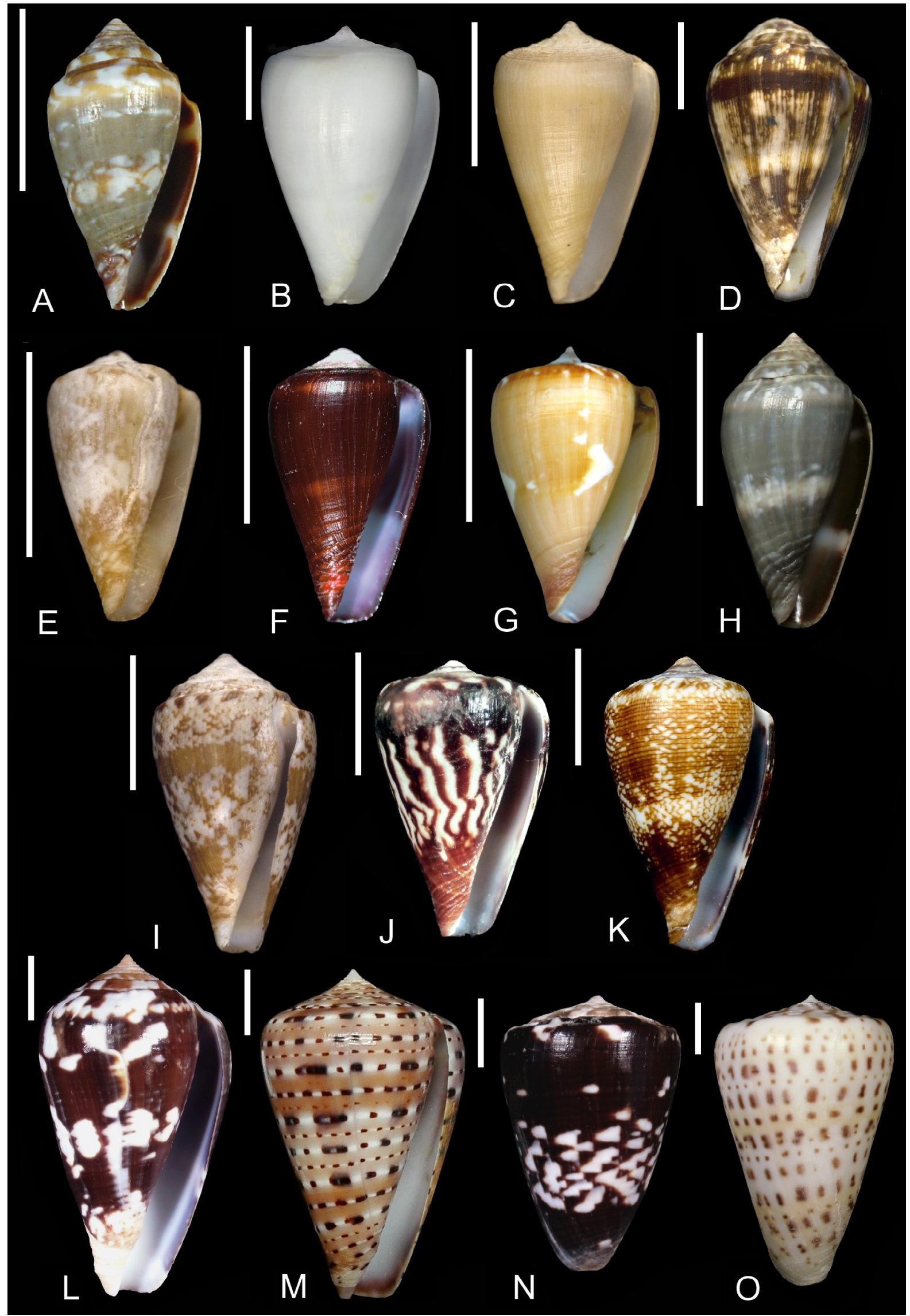


Africonus salletae Cossignani, 2014

Fig. $6 \mathrm{~F}$

Africonus salletae Cossignani, 2014: 25.

\section{Material examined}

Holotype

CABO VERDE • $15.5 \mathrm{~mm}$; Boa Vista Island, Espingueira; 0.5-2 m depth; MMM (Fig. 6F).

\section{Geographical distribution}

Only known from the type locality.

\section{Conservation status in IUCN Red List}

Not evaluated.

\section{Remarks}

This relatively recently described species has not been examined in detail. It is morphologically (and most likely phylogenetically also) related to A. fuscoflavus. It is hereby considered as provisionally valid only, pending confirmation by future molecular analyses.

\section{Africonus santaluziensis Cossignani \& Fiadeiro, 2015}

Fig. 6G

Africonus santaluziensis Cossignani \& Fiadeiro, 2015c: 5.

Type material (not examined)

\section{Holotype}

CABO VERDE • 21.6 mm; Santa Luzia Island, Baía de Água Doce; 2-6 m depth; MMM.

\section{Paratype}

CABO VERDE • 1 spec., $28.1 \mathrm{~mm}$; same collection data as for holotype; Paul Kersten collection (Hoornaar, The Netherlands) (Fig. 6G).

\section{Geographical distribution}

Only known from the type locality.

\section{Remarks}

This recently described species has not been examined. We did not find individuals in our survey of Santa Luzia in 2016. Given the observed genetic divergence present in most of the taxa reported from the islands of São Vicente and Santa Luzia, we consider this taxon as provisionally valid pending future detailed molecular studies.

\section{Africonus santanaensis Afonso \& Tenorio, 2014}

Fig. $6 \mathrm{H}$

Africonus santanaensis Afonso \& Tenorio, 2014: 49, pl. 1, figs 1-6.

Africonus gonsalensis Cossignani \& Fiadeiro, 2014b: 25. 
TENORIO M.J. et al., Taxonomic revision of West African cone snails

\section{Material examined}

\section{Holotype}

CABO VERDE • 17.1 mm; Maio Island, Praia Santana; C.M.L. Afonso leg.; MNCN 15.05/60118 (Fig. 6H).

\section{Geographical distribution}

Northwest and northeast coasts of Maio Island, Cabo Verde Archipelago.

\section{Conservation status in IUCN Red List}

Not evaluated.

\section{Remarks}

This species has not been molecularly examined. Its radular tooth morphology suggests a relationship to the species A. calhetae or A. galeao, but its distinctly elongated shell shape readily separates it from the latter two. Initially described from the area of Praia Santana, to the northwest of Maio, a population recently introduced as $A$. gonsalensis from Praia Gonçalo, to the northeast of the island, has an almost identical shell morphology and is therefore considered conspecific. The description of $A$. santanaensis was published in April 2014, and the taxon A. gonsalensis appeared in July 2014. Hence, A. gonsalensis becomes a junior synonym for $A$. santanaensis.

\section{Africonus saragasae (Rolán, 1986)}

Fig. 6I

Conus saragasae Rolán, 1986: 7, fig. 1C.

Conus cuneolus form E (not C. cuneolus Reeve, 1843) - Röckel et al. 1980a: 105, pl. 6, row 5c-d, fig. 81.

Conus saragasae - Monteiro et al. 2004: 71, pls 83-84.

\section{Material examined}

\section{Holotype}

CABO VERDE • 21.8 mm; São Vicente Island, Punta Saragaça; E. Rolán leg.; MNCN 15.05/1009 (Fig. 6I).

\section{Geographical distribution}

São Vicente and Santa Luzia islands, Cabo Verde Archipelago.

\section{Conservation status in IUCN Red List}

Near threatened.

\section{Remarks}

Prior to its introduction as a full species by Rolán (1986), it was referred to as Conus cuneolus form E in Röckel et al. (1980a). This species has not been molecularly examined. Given the observed genetic divergence present in the taxa reported from the islands of São Vicente and Santa Luzia, we consider this taxon as provisionally valid pending future detailed molecular studies.

\section{Africonus verdensis (Trovão, 1979)}

Fig. $6 \mathrm{~J}$

Conus verdensis Trovão, 1979: 5, pl. 1, fig. 3.

Africonus nelsontiagoi Cossignani \& Fiadeiro, 2014b: 26. 
Conus verdensis verdensis - Monteiro et al. 2004: 80, pl. 81, pl. 82, figs 6, 9 .

Conus cuneolus form M (not C. cuneolus Reeve, 1843) - Röckel et al. 1980a: 113, pl. 6, row 5a-b, fig. 95B.

\section{Material examined}

\section{Holotype}

CABO VERDE - $17.1 \mathrm{~mm}$; "Santa Luzia Island" [erroneous, hereby corrected to Santiago Island, Tarrafal]; NHMUK 1986195.

\section{Other material}

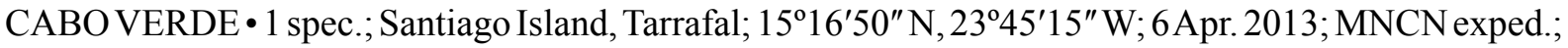
GenBank mitochondrion, partial genome: MF491540; MNCN 15.05/78865 • 1 spec.; same collection data as for preceding; GenBank mitochondrion, partial genome: MF491541; MNCN 15.05/78875 • 1 spec., $22.5 \mathrm{~mm}$; same collection data as for preceding; MNCN 15.05/78864 (Fig. 6J).

\section{Geographical distribution}

Santiago Island, Cabo Verde Archipelago.

\section{Conservation status in IUCN Red List}

Least concern.

\section{Remarks}

The type locality for this species is most likely erroneous, as it seems to be endemic to Santiago Island, being particularly abundant around the Tarrafal area to the northwest. The species introduced under the name nelsontiagoi had been illustrated and referred to as Conus cuneolus form $\mathrm{M}$ in Röckel et al. (1980a). This form appears distributed mostly along the east coast of Santiago Island, with a transition area to the north where it intergrades with typical $A$. verdensis. Morphological studies of shell and radula had already suggested the close relationship of this morph with the taxon A. verdensis (Rolán 2005). The molecular phylogeny and mitochondrial genome sequence divergences support the conspecificity of nelsontiagoi with $A$. verdensis.

\section{Africonus vulcanus (Tenorio \& Afonso, 2004)}

Fig. $6 \mathrm{~K}$

Conus vulcanus Tenorio \& Afonso, 2004: 25, pl. 1.

Africonus miguelfiadeiroi Cossignani \& Fiadeiro, 2015c: 3.

\section{Material examined}

\section{Holotype}

CABO VERDE • 25.2 mm; Boa Vista Island, Porto Ferreira; MJT leg.; MNCN 15.05/46652 (Fig. 6K).

\section{Other material}

CABO VERDE • 1 spec.; Boa Vista Island, Porto Ferreira; 167'45" N, 2240'17" W; 1 Jul. 2013; MNCN exped.; GenBank mitochondrion, partial genome: MF491555; MNCN 15.05/80405 • 1 spec.; Boa Vista Island, Praia Canto; 16 ${ }^{\circ} 11^{\prime} 10^{\prime \prime}$ N, 22 $2^{\circ} 42^{\prime} 28^{\prime \prime}$ W; 6 Apr. 2013; MNCN exped.; GenBank mitochondrion, partial genome: MF491554; MNCN 15.05/80404 • 1 spec.; Boa Vista Island, Jorrita, Baía das Gatas; $16^{\circ} 12^{\prime} 9^{\prime \prime}$ N, 22 $2^{\circ} 42^{\prime} 22^{\prime \prime}$ W; 6 Apr. 2013; MNCN exped.; GenBank mitochondrion, partial genome: MF491548; MNCN 15.05/80398. 


\section{Geographical distribution}

East and northeast coasts of Boa Vista Island, Cabo Verde Archipelago.

\section{Conservation status in IUCN Red List}

Least concern.

\section{Remarks}

There are at least three distinctive populations of this taxon distributed along the east and northeast coasts of Boa Vista Island. One of them from Praia Canto was introduced as a distinct species named Africonus miguelfiadeiroi, but upon comparison of its mitogenome sequence, as well as its radular anatomy, we conclude that it is conspecific with A. vulcanus, representing a mere color form. In analogous fashion, the mitogenomic analysis of an individual from Jorrita, in Baía das Gatas belonging to a yet unnamed population often confused with $A$. evorai (a morph of $A$. crotchii), indicates that the individuals of this population are also conspecific with $A$. vulcanus, thus expanding the known range of this species to the north. A. vulcanus is phylogenetically very close to its sister species $A$. delanoyae (see above).

\section{Genus Chelyconus Mörch, 1852}

\section{Chelyconus ermineus (Born, 1778)}

Fig. 6L

Conus ermineus Born, 1778: 141.

Conus oculatus Gmelin, 1791: 3387.

Conus testudinarius Hwass in Bruguière, 1792: 694.

Conus eques Hwass in Bruguière, 1792: 705.

Conus luzonicus Hwass in Bruguière, 1792: 706.

Conus portoricanus Hwass in Bruguiére, 1792: 714.

Cucullus barathrum Röding, 1798: 43.

Cucullus crucifer Röding, 1798: 48.

Cucullus cutisanguina Röding, 1798: 48.

Conus coerulescens Schröter, 1803: 67.

Conus leaeneus Link, 1807: 103.

Conus narcissus Lamarck, 1810: 281.

Conus coerulescens Dillwyn, 1817: 368.

Conus aspersus G.B. Sowerby I, 1833: pl. 28, fig. 16.

Conus caerulans Küster, 1838: pl. 14, figs 3-4.

Conus grayi Reeve, 1844: pl. 46. sp. 258, a-c.

Conus inquinatus Reeve, 1849: pl. 5, sp. 251.

Conus rudis Weinkauff, 1873: 158, pl. 10, figs 1-2.

Conus verrucosus piraticus Clench, 1942: 14, pl. 11, fig. 1 .

Conus perryae Clench, 1942: 31, pl. 15, fig. 5.

Conus ermineus - Monteiro et al. 2004: 41, pls 14-16.

\section{Material examined}

\section{Lectotype}

Lectotype in NHMW. Type locality not mentioned in 1778 in the original description. 


\section{Other material}

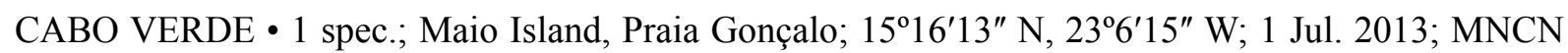
exped.; GenBank mitochondrion, partial genome: KY864977; MNCN 15.05/78876 • 1 spec.; Boa Vista Island, Porto do Derrubado; $16^{\circ} 13^{\prime 2} 22^{\prime \prime}$ N, 22 ${ }^{\circ} 47^{\prime} 41^{\prime \prime}$ W; 3 Jul. 2013; MNCN exped.; MNCN 15.05/80980

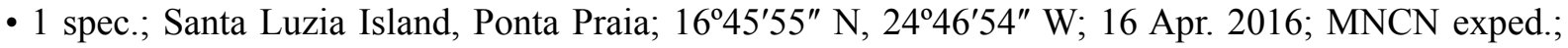

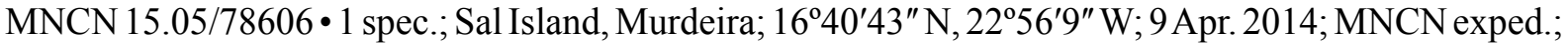
MNCN 15.05/80013 • 1 spec., $54.3 \mathrm{~mm}$; same collection data as for preceding; MNCN 15.05/80014 (Fig. 6L).

\section{Geographical distribution}

West and East Atlantic Ocean.

\section{Conservation status in IUCN Red List}

Least concern.

\section{Remarks}

This is an amphiatlantic (i.e., present on both shores of the Atlantic Ocean) species and the only piscivorous cone in the Atlantic Ocean. Its venom has been subject of detailed proteomic (Rivera-Ortiz et al. 2011; Quinton et al. 2013; Echterbille et al. 2017) and transcriptomic (Abalde et al. 2018) studies. It is widely distributed along the West African coast, being locally abundant at certain locations, but nowadays it is much more scarce in the western Atlantic than in the past. For a long time it has been speculated that possibly the eastern and western Atlantic populations might represent two separate species. Until detailed molecular studies are performed including the entire mitogenome examination of western Atlantic individuals, we maintain all the populations from both shores of the Atlantic Ocean as members of the same species, namely Chelyconus ermineus.

Genus Genuanoconus Tucker \& Tenorio, 2009

Genuanoconus genuanus (Linnaeus, 1758)

Fig. $6 \mathrm{M}$

Conus genuanus Linnaeus, 1758: 714.

Conus genuanus var. papilio Linnaeus, 1767: 1168.

Cucullus papilio Röding, 1798: 41.

Cucullus sphinx Röding, 1798: 42.

Conus fasciatus Perry, 1811: pl. XXIV, no. 3.

Conus genuanus - Monteiro et al. 2004: 48, pl. 17.

\section{Material examined}

Lectotype

Representation of lectotype in Rumphius (1705: pl. 34, fig. G) (Kohn 1963). Type locality not stated.

\section{Other material}

CABO VERDE • 1 spec., 50.2 mm; São Vicente Island, Praia de Laginha; 10 Apr. 2016; S. Delgado and P. Vasconcelos leg.; GenBank mitochondrion, partial genome: KY864974; MNCN 15.05/78547 (Fig. 6M). 
TENORIO M.J. et al., Taxonomic revision of West African cone snails

\section{Geographical distribution}

West Africa, from Senegal to Angola including Cabo Verde Archipelago and São Tomé e Príncipe. There are occasional reports of live specimens found on the Canary Islands (Bettocchi 2018), where it is exceedingly rare.

\section{Conservation status in IUCN Red List}

Least concern.

\section{Remarks}

This is a typical West African species, being the only representative of the genus Genuanoconus. The different names available in the literature have all been synonymised with $G$. genuanus. The name foscaclaudiae Assi, 2010 applied to a mere form of G. genuanus is unavailable according to the ICZN articles 45.5 and 45.6 (infrasubspecific; introduced as form after 1960). As discussed in Abalde et al. (2019), the previous placement of G. genuanus in the genus Kalloconus by Puillandre et al. (2014) was due to a misidentification of a sample in the original work (Cunha et al. 2005). A mitogenomic analysis clearly indicates that Genuanoconus is not a synonym of Kalloconus but a distantly related genus. Genuanoconus genuanus has an specialized vermivorous diet, preying on amphinomid polychaetes (fireworms) such as Hermodice carunculata (Pallas, 1766) (Rolán 2005). On the phylogenetic tree in Abalde et al. (2019), G. genuanus is recovered as sister to Rhombiconus imperialis Linnaeus, 1758, another specialised amphinomid polychaete worm eater from the Pacific Ocean. A novel bioactive guanine derivative named genuanine has been isolated from the venom duct of G. genuanus. This finding indicates that not only conopeptides, but also small molecules contribute to the activity of cone snail venoms (Neves et al. 2015).

Genus Kalloconus Da Motta, 1991

Trovaoconus Tucker \& Tenorio, 2009: 126-127, pl. 8, fig. 2.

Kalloconus ateralbus (Kiener, 1850)

Fig. $6 \mathrm{~N}$

Conus ateralbus Kiener, 1850: 313, pl. 108, fig. 4-4a.

Conus ateralbus - Monteiro et al. 2004: 25, pl. 46, pl. 47, figs 1, 3-4, 6.

\section{Material examined}

\section{Lectotype}

Two syntypes were in collection Lorois, present whereabouts unknown; lectotype representative figure in Kiener (1845 (1850): pl. 108, fig. 4, top and bottom). Type locality not mentioned, designated Sal Island, Cabo Verde (Coomans et al. 1981).

\section{Other material}

CABO VERDE • 1 spec., 40.1 mm; Sal Island, Calheta Funda; 16³9'6" N, 22 $56^{\prime} 53^{\prime \prime}$ W; 5 Apr. 2014; MNCN exped.; GenBank mitochondrion, partial genome: KY864970; MNCN 15.05/79649 (Fig. 6N).

\section{Geographical distribution}

Calheta Funda and Algodoeiro, southwest coast of Sal Island, Cabo Verde Archipelago. 


\section{Conservation status in IUCN Red List}

Endangered. Status revision required.

\section{Remarks}

This beautiful species is endemic to Sal Island. Its pattern of white triangular or tessellate markings on a black background color seems fairly constant. Its classification as 'Endangered' resulted upon considering all the populations of Kalloconus on the island as members of this species. Several phylogenetic studies (Cunha et al. 2008; Abalde et al. 2017a; Tenorio et al. 2018) have shown that under the apparently same phenotype there are actually two cryptic sister species in Sal Island, namely $K$. ateralbus and $K$. marimaris. As a consequence, the distribution range of $K$. ateralbus has been drastically reduced to the southwest coast of Sal Island, an area that has underwent a large touristic development in the recent years, with subsequent pressure on marine habitats. Although the species seems to be fairly common within its distribution range, the limited geographical area and the human activities indicate that an upgrade in the risk status is most likely required.

\section{Kalloconus byssinus (Röding, 1798)}

Fig. $6 \mathrm{O}$

Cucullus byssinus Röding, 1798: 41.

Conus pulcher byssinus - Monteiro et al. 2004: 68, pls 22-23.

\section{Material examined}

\section{Lectotype}

Representation of lectotype in Martini (1773: pl. 60, fig. 669) (Kohn 1975). Type locality not stated, designated Villa Cisneros (now Dakhla), Western Sahara (Coomans et al. 1982).

\section{Other material}

MAURITANIA • 1 spec., 56.4 mm; Noadibou; MNCN 15.05/90429 (Fig. 6O).

\section{Geographical distribution}

Western Sahara and Mauritania.

\section{Conservation status in IUCN Red List}

Not evaluated.

\section{Remarks}

Specimens from the type locality have not been molecularly examined. However, the mitogenome of a specimen from Senegal with a shell morphology matching that of typical $K$. byssinus is almost identical to that of $K$. pulcher (Abalde et al. 2017a). There are no significant differences between the radular teeth of $K$. pulcher and $K$. byssinus. Although we consider $K$. byssinus as provisionally valid only, pending molecular examination of specimens from the type locality, it is however likely that this taxon represents just a phenotypic variation of the widespread $K$. pulcher, typical of the northern end of its distribution range along the West African coast.

Kalloconus canariensis sp. nov. urn:1sid:zoobank.org:act:E99E63BE-07D8-497D-935C-EA966F0EE9D6

Fig. 7A-I

Conus pulcher siamensis (not C. siamensis Hwass in Bruguiére, 1792) - Monteiro et al. 2004: pl. 24, figs 1-6, pl. 25, figs 1-3. 
TENORIO M.J. et al., Taxonomic revision of West African cone snails

Kalloconus siamensis (not C. siamensis Hwass in Bruguiére, 1792) - Monnier et al. 2018: 1078, figs 1-5.

\section{Etymology}

The name canariensis refers to its distribution range throughout the Canary Islands. The name 'canariensis' van Rossum, 1997 is an unavailable forma name (nomen nudum; no intention to introduce a new name, stated to be infrasubspecific after 1960) that has been occasionally and incorrectly been used to refer to specimens with pulcher-like shells from the Canary Islands. The name has usually been applied to subadult specimens with a characteristic sparse pattern of purplish brown dots and dashes aligned in a spiral on a creamy white background with two broad light brown spiral bands (Fig. 7I). We hereby rescue this name for the new taxon and provide a formal description compliant with ICZN standards.

\section{Material examined}

\section{Holotype}

SPAIN - Canary Islands • $89.0 \mathrm{~mm}$; Las Palmas de Gran Canaria, Municipio de Telde, Playa de Tufia; 27 $57^{\prime} 43^{\prime \prime} \mathrm{N}, 1^{\circ} 22^{\prime} 45^{\prime \prime} \mathrm{W}$; MNCN exped.; GenBank mitochondrion, partial genome: MT240810; MNCN 15.05/200091H (Fig. 7A-B).

\section{Paratypes}

SPAIN - Canary Islands • 1 spec., $85.3 \mathrm{~mm}$; same collection data as for holotype; MNCN 15.05/200091P (Fig. 7C, paratype 1) $\bullet 1$ spec., $132.0 \mathrm{~mm}$; Lanzarote, Mala, Charco del Palo; MNCN exped.; MNCN 15.05/200094 (Fig. 7F, paratype 2) • 1 spec., 92.1 mm; Tenerife, Punta de Teno; R. Vega leg.; MNCN 15.05/200093 (Fig. 7E, paratype 3) 1 spec., 93.9 mm; Santa Cruz de la Palma, south of the harbor; MNCN exped.; MNCN 15.05/200092 (Fig. 7G, paratype 4) • 1 spec., $76.3 \mathrm{~mm}$; same collection data as for preceding; MNCN 15.05/200092 (Fig. 7D, paratype 5) 1 spec., $47.4 \mathrm{~mm}$; same collection data as for holotype; MNCN 15.05/200091P (Fig. 7H, paratype 6) 1 spec., $43.3 \mathrm{~mm}$; Lanzarote, Municipio de Yaiza, Playa Quemada; MNCN exped.; MNCN 15.05/200095 (Fig. 7I, paratype 7).

\section{Other material}

About 35 more specimens from different localities in the Canary Islands.

\section{Description}

Morphometric Parameters. $\mathrm{S}_{\mathrm{L}}=47-167 \mathrm{~mm}\left(\right.$ mean $\left._{\mathrm{L}}=96.7 \mathrm{~mm}\right) ; \mathrm{RD}=0.61-0.74 ; \mathrm{RSH}=0.07-0.12$; $\mathrm{PMD}=0.61-0.73$.

SHELl. Moderately large to very large. Maximum length: $167 \mathrm{~mm}$. Shell profile conical to broadly conical, with convex sides adapically, straight or slightly concave below. Spire low, of straight to concave outline, some times slightly stepped. Protoconch white. Teleoconch whorls smooth, flat or slightly concave. Shoulder angulate or subangulate. Area below the shoulder often swollen, conferring a turnip-shaped appearance to certain specimens. Early teleoconch whorls white. Late teleoconch whorls white with radial brown irregular blotches. Ground color white. Last whorl overlaid in variable amount with alternating purplish brown and white spiral bars, as well as lines of dots and dashes in different shades of brown on light brown-orange and white broader spiral bands. Two sparsely patterned spiral bands located respectively above and below the midbody, where the white ground color predominates. Similar spiral band often present around basal region, just above the columella. Great variability in the color pattern, with shades of purple, brown and orange, which tend to fade with time to a more uniform brown color. Young specimens with characteristic sparse pattern of purplish brown dots and dashes aligned in spirals on creamy white background with two broad light brown to white spiral bands (Fig. 9I). Columella white to light purple. Aperture white. Periostracum yellow-brown, thin and translucent. 

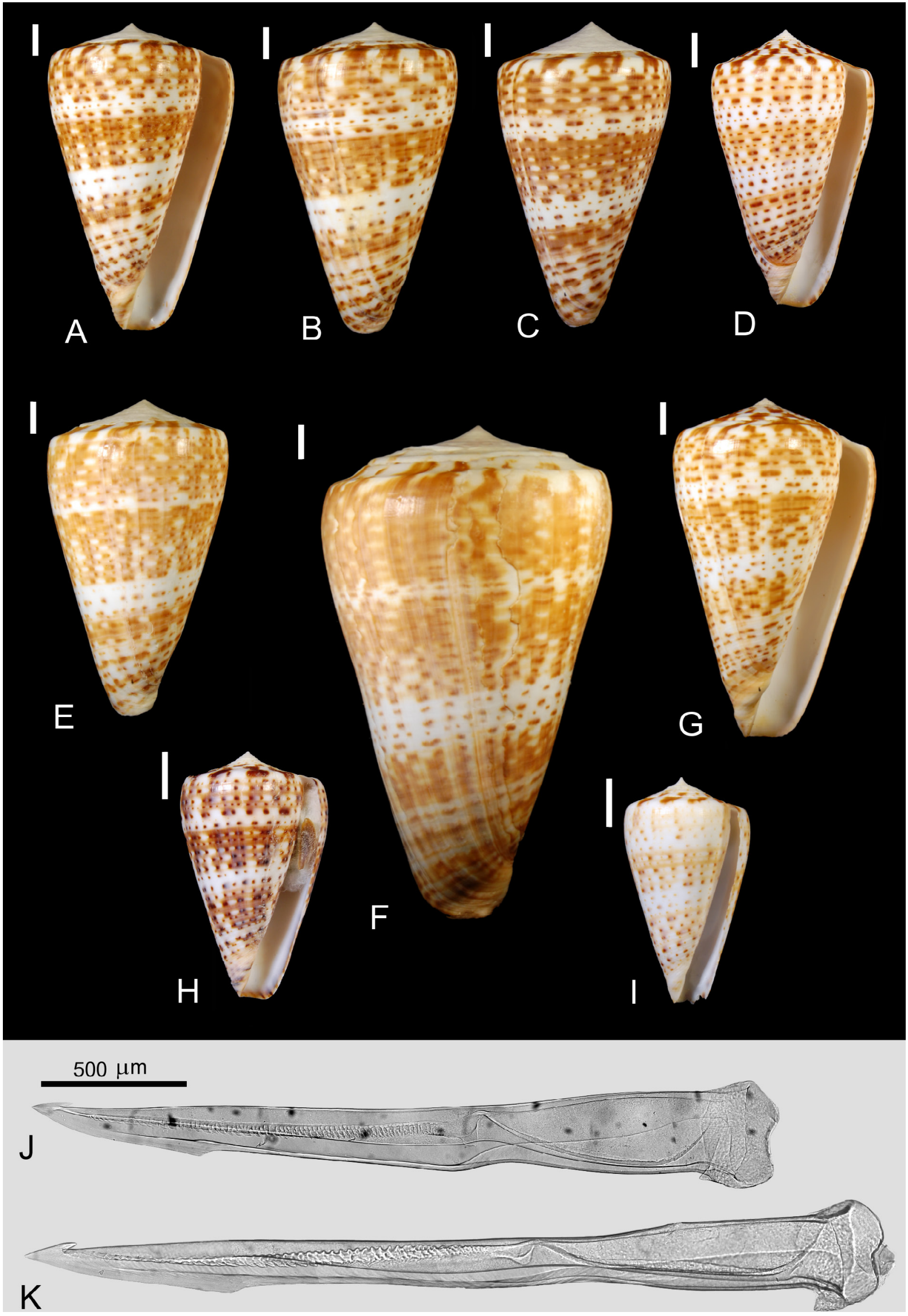
AnImaL. Sole of foot tan to light brown with brown streaks. Dorsum of foot of same color, overlaid with purplish brown irregular markings. Siphon yellowish white with dark purple tip. Mantle off-white, bordered with thin yellowish ribbon. Operculum small, teardrop shaped.

RADULAR тоOтH. Radula studied from two specimens, including paratype 1 (Fig. 7J). Radular tooth of medium relative size $\left(\mathrm{S}_{\mathrm{L}} / \mathrm{T}_{\mathrm{L}}=36-49\right)$, with short, but well-developed apical barb. Anterior section distinctly longer than posterior section of tooth $\left(\mathrm{T}_{\mathrm{L}} / \mathrm{AP}_{\mathrm{L}}=1.59-1.63\right)$. Waist rather indistinct, not very well marked. Blade moderately short and rounded, covering about one third to one half of anterior section $\left(100 \mathrm{~B}_{\mathrm{L}} / \mathrm{AP}_{\mathrm{L}}=39-48 \%\right)$. Serration with 50-55 denticles, arranged in major row flanked by numerous smaller serrations. Rounded terminating cusp present. A basal spur is present.

\section{Distribution and habitat}

Canary Islands. Its potential presence outside this archipelago (i.e., Madeira) needs confirmation.

\section{Conservation status in IUCN Red List}

Not evaluated.

\section{Remarks}

Mitogenomic analyses have revealed that the populations of pulcher-like cones from the Canary Islands actually correspond to a separate species hereby introduced as $K$. canariensis sp. nov., sister to $K$. pulcher (Figs 2, 8A) and most likely endemic to this archipelago. This species is present on all the islands, living between 1 and $50 \mathrm{~m}$ deep, most frequently between 5 and $20 \mathrm{~m}$. The shell of $K$. canariensis sp. nov. usually is more brightly colored than that of $K$. pulcher, with shades of purple and orange in the pattern which are usually absent in the latter. In K. canariensis sp. nov. the area below the shoulder is often swollen, conferring a somewhat turnip-shaped appearance. However, these differences are not constant. Furthermore, there are no statistically significant differences in mean shell length or maximum diameter between $K$. pulcher and $K$. canariensis sp. nov.: a comparison of two sets constituted by 40 individuals of $K$. canariensis sp. nov. and 40 individuals of $K$. pulcher did not yield significant results in ANOVA tests using species as factor and $S_{L}(F=2.96, p=0.0892)$ or $\mathrm{MD}(\mathrm{F}=2.40, \mathrm{p}=0.1254)$ as variables. Likewise, and analysis of the covariance using species as factor, $\mathrm{MD}$ as variable and $\mathrm{S}_{\mathrm{L}}$ as covariate did not yield significant results either $(\mathrm{F}=0.32, \mathrm{p}=0.5762)$. Despite the fact that individuals of $K$. pulcher (especially those coming from the Gulf of Guinea) may attain a greater maximum shell lenght than individuals of $K$. canariensis sp. nov., actually there is no statistically significant difference in mean shell lenght between the two species: mean $\mathrm{S}_{\mathrm{L}}=96.7 \mathrm{~mm}$ for $K$. canariensis sp. nov., and mean $\mathrm{S}_{\mathrm{L}}=110.2 \mathrm{~mm}$ for $K$. pulcher $(\mathrm{t}=-1.721, \mathrm{p}=0.089 ; \mathrm{U}=618.5$, $\mathrm{p}=0.082$ ). There are no significant differences either in the radular teeth of both species (Fig. $7 \mathrm{~J}-\mathrm{K}$ ), suggesting similar dietary habits. Hence, the separation of $K$. pulcher and $K$. canariensis sp. nov. based upon shell and radular morphologies cannot always be accurate, relying only on subtle differences in shell features and pattern. The name siamensis Hwass in Bruguiére, 1792 has been used in the literature to refer to these cones from the Canary Islands, either as a separate species (Monnier et al. 2018) or as a geographic subspecies (Röckel 1978, 1982; Monteiro et al. 2004; Filmer 2011). This name

Fig. 7 (opposite page). Kalloconus canariensis sp. nov. A-B. Holotype (dorsal and ventral views), 89.0 mm (MNCN 15.05/200091H). C. Paratype 1, $85.3 \mathrm{~mm}$ (MNCN 15.05/200091P). D. Paratype 5, $76.3 \mathrm{~mm}$ (MNCN 15.05/200092). E. Paratype 3, $92.1 \mathrm{~mm}$ (MNCN 15.05/200093). F. Paratype 2, $132.0 \mathrm{~mm}$ (MNCN 15.05/200094). G. Paratype 4, $93.9 \mathrm{~mm}$ (MNCN 15.05/200092). H. Paratype 6, $47.4 \mathrm{~mm}$ (MNCN 5.05.200091P). I. Paratype 7, $43.3 \mathrm{~mm}$ (MNCN 15.05/200095). J-K. Radular tooth. K. K. canariensis sp. nov., paratype 1. K. K. pulcher ([Lightfoot], 1786), Joal Fadiouth, Senegal (MJT), $\mathrm{SL}=96.7 \mathrm{~mm}$. Scale bars $=10 \mathrm{~mm}$ unless otherwise indicated. 
has been synonymized with pulcher ([Lightfoot, 1786]) by several authors (Kohn 1992; van Rossum 1997). However, the type locality of siamensis is "Indian Ocean" (erroneous). The dimensions of the lectotype of Conus siamensis at MHNG (Fig. 9B) overlap completely with those of both K. pulcher and $K$. canariensis sp. nov. (Fig. 8). Hence, it is not possible the unambiguous assignation of the lectotype of $C$. siamensis as representative of the new species constituted by the individuals from the Canary Islands based upon its shell features only. Therefore, we consider the name siamensis as a junior synonym of pulcher in agreement with Kohn (1992), and the new name K. canariensis sp. nov. is hereby introduced for species from the Canary Islands.

Kalloconus marimaris Tenorio, Abalde \& Zardoya, 2018

Fig. 9C-D

Kalloconus marimaris Tenorio et al., 2018: 75, pl. 1, figs a-m.

Conus ateralbus (not C. ateralbus Kiener, 1850) - Monteiro et al. 2004: pl. 47, figs 2, 5, 7, pls 48-49. Conus venulatus (not $C$. venulatus Hwass in Bruguiére, 1792) - Monteiro et al. 2004: pl. 52, figs 1, 3.

\section{Material examined}

\section{Holotype}

CABO VERDE • 38.6 mm; Sal Island, Serra Negra; $16^{\circ} 38^{\prime} 16.5^{\prime \prime}$ N, 22 $2^{\circ} 53^{\prime} 56^{\prime \prime}$ W; $1-3$ m depth; 5 Apr. 2014; MNCN exped.; GenBank mitochondrion, partial genome: MF491568; MNCN 15.05/79664 (Fig. 9C).

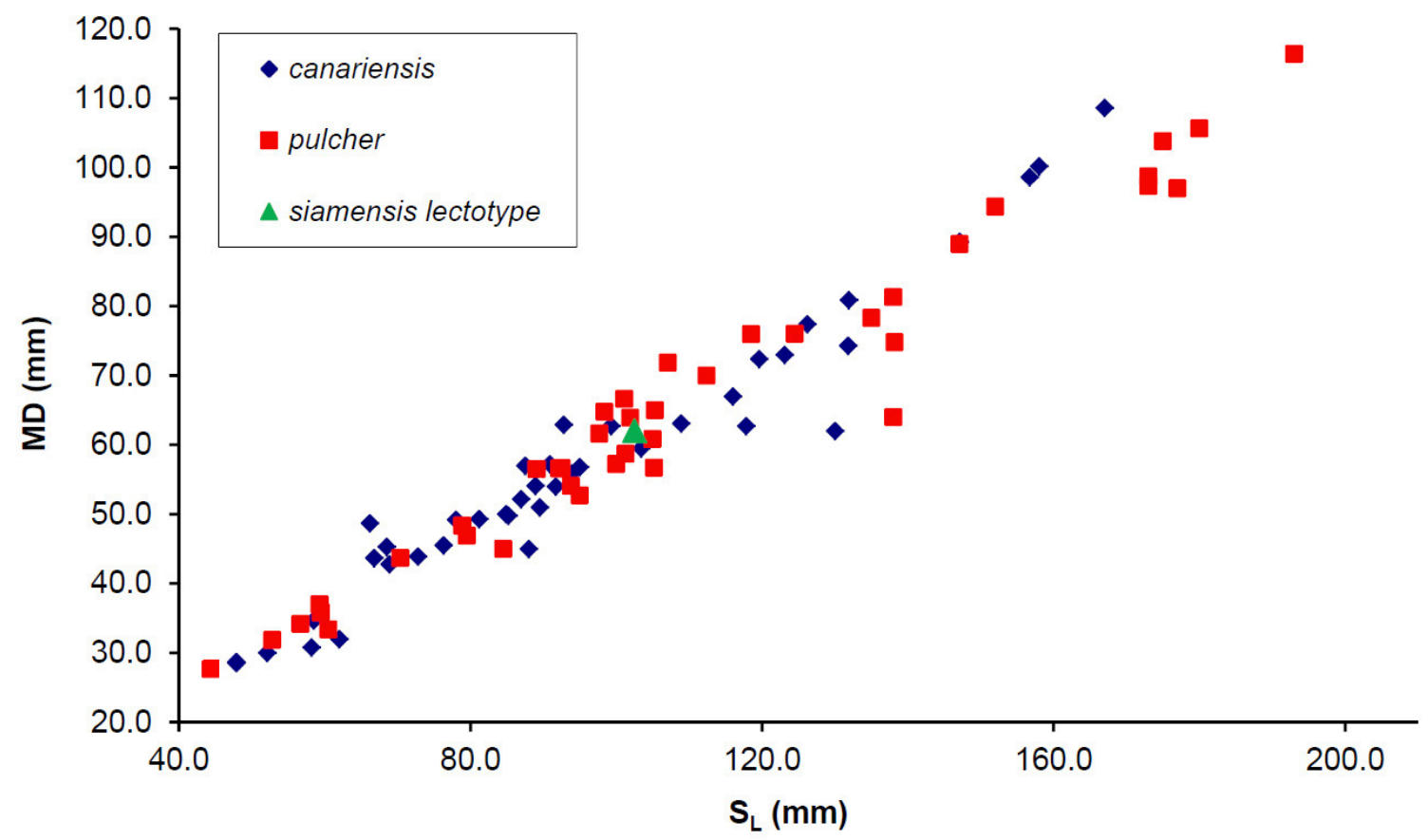

Fig. 8. Plot of maximum diameter (MD, $\mathrm{mm})$ versus shell length $\left(\mathrm{S}_{\mathrm{L}}, \mathrm{mm}\right)$ for $K$. canariensis sp. nov. $(\diamond)$ and $K$. pulcher ([Lightfoot], 1786) (অ). The lectotype of K. siamensis (Hwass in Bruguiére, 1792) $(\Delta)$ is also shown. 
TENORIO M.J. et al., Taxonomic revision of West African cone snails

\section{Other material}

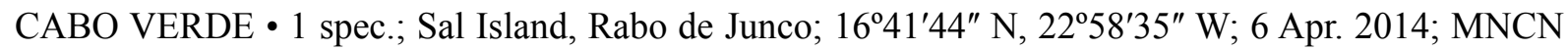
exped.; GenBank mitochondrion, partial genome: MH243427; MNCN 15.05/79687 • 1 spec., $36.6 \mathrm{~mm}$; same collection data as for preceding; GenBank mitochondrion, partial genome: MH243428; MNCN 15.05/79689 (Fig. 9D).

\section{Geographical distribution}

West (Murdeira, Rabo de Junco) and east (Serra Negra) coasts of Sal Island, Cabo Verde Archipelago.

\section{Conservation status in IUCN Red List}

Not evaluated.

\section{Remarks}

This recently described species was formerly identified as $K$. venulatus or $K$. ateralbus. Kalloconus venulatus is absent from Sal Island, and $K$. ateralbus has enough mitogenome sequence divergence to be considered a separate species, sister to $K$. marimaris (see above). The latter is split into two populations inhabiting areas to the east and west coasts of Sal Island. This species has some morphological similarities to $K$. ateralbus and hence the confusion. Kalloconus marimaris is very variable in background color, with yellow, orange, milky white or brown morphs, whereas in $K$. ateralbus the background color is always black.

Kalloconus pseudonivifer (Monteiro, Tenorio \& Poppe, 2004)

Fig. 9E

Conus pseudonivifer Monteiro et al., 2004: 66, pl. 60, figs 4-7, pl. 61, figs 5-7.

\section{Material examined}

\section{Holotype}

CABO VERDE • 47.4 mm; Boa Vista Island, Baía das Gatas; MNCN 15.05/46627 (Fig. 9E).

\section{Other material}

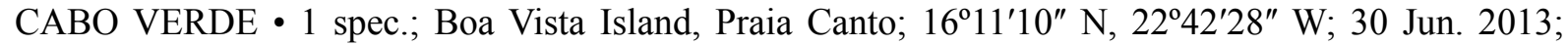
MNCN exped.; GenBank mitochondrion, partial genome: MF491553; MNCN 15.05/80403 - 1 spec.; same collection data as for preceding; GenBank mitochondrion, partial genome: MT240804; MNCN $15.05 / 78591$.

\section{Geographical distribution}

East and northeast coast of Boa Vista Island.

\section{Conservation status in IUCN Red List}

Least concern. Status revision required.

\section{Remarks}

This name was introduced in order to solve the existing confusion with the name Conus nivifer G.B. Sowerby I, 1833 (a synonym of Conus venulatus Hwass in Bruguière, 1792) which had been incorrectly applied to shells from Cabo Verde having a bluish white background with a distinctive pattern of spiral interrupting thick lines of deep purple or dark brown and a purple aperture (Monteiro et al. 2004). The specimens of this species are morphologically very close to K. trochulus (Reeve, 1844), and in fact the latter might be considered as a patternless version of $K$. pseudonivifer. Previous population genetic analyses 
showed that most specimens of individuals identified as K. pseudonivifer from Boa Vista and Maio islands clustered with $K$. trochulus, with the exception of one specimen from Praia Canto in northeast Boa Vista Island (Cunha et al. 2008). We examined the mitogenome of many individuals of alleged $K$. pseudonivifer from Boa Vista and Maio islands (Abalde et al. 2017a). As in Cunha et al. (2008), all individuals but the one from northeast Boa Vista Island clustered together with $K$. trochulus (Abalde et al. 2017a). Here, we sequenced the mitogenome of a second specimen from Praia Canto in northeast Boa Vista Island, which confirmed the segregation of these two individuals from the clade grouping $K$. trochulus with pseudonivifer-like individuals, at a genetic distance consistent with separate species status (Fig. 2). Given the fact that the type locality of the taxon Conus pseudonivifer is "Baía das Gatas", which is located to the northeast of Boa Vista Island, the name pseudonivifer is only applicable to specimens distributed along the east and northeast coasts of the island, whereas the specimens from other areas should be considered patterned forms of $K$. trochulus.

Kalloconus pulcher ([Lightfoot], 1786)

Fig. 9A-B

Conus pulcher [Lightfoot], 1786: 179, no. 3844.

Conus siamensis Hwass in Bruguière, 1792: 662.

Conus papilionaceus Hwass in Bruguière, 1792: 665.

Conus prometheus Bruguière, 1792: 667.

Cucullus indiae Röding, 1798: 43.

Conus archithalassius Link, 1807: 102.

Conus gigas Fischer von Waldheim, 1807: 140.

Conus fluctifer Dillwyn, 1817: 382.

Conus grandis G.B. Sowerby I, 1823: pl. 266, fig. 2.

Conus nicolii Wilson, 1831: pl. XXXVI.

Conus papillaris G.B. Sowerby I, 1833: pl. 37, fig. 54.

Conus breviculus G.B. Sowerby I, 1833: pl. 37, fig. 55.

Conus pulcher pulcher - Monteiro et al. 2004: 67, pls 18-21.

\section{Material examined}

\section{Lectotype}

Representation of lectotype in Lister et al. (1688: pl. 772, fig. 18) (Kohn 1964). Type locality: coasts of Guinea (West Africa).

\section{Other material}

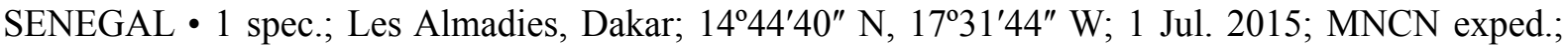
GenBank mitochondrion, partial genome: KY864972; MNCN 15.05/78414 • 1 spec.; between Dakar and St. Louis; 7 Jul. 2015; L. Tamagnini leg.; GenBank mitochondrion, partial genome: KY864973; MNCN 15.05/78536.

GUINEA • 1 spec., 136 mm; off Conakry; 50-60 m depth; MJT (Fig. 9A).

"INDIAN OCEAN" (erroneous) • 1 spec., lectotype of C. siamensis, $102 \mathrm{~mm}$; MHNG-MOLL-52702 (Fig. 9B).

\section{Geographical distribution}

West Africa, from Senegal to Angola. Not present in the Cabo Verde Archipelago. 
TENORIO M.J. et al., Taxonomic revision of West African cone snails

\section{Conservation status in IUCN Red List}

Least concern.

\section{Remarks}

This is the largest-sized extant species of cone snail worldwide. Specimens from the Gulf of Guinea can exceed $200 \mathrm{~mm}$ in shell length. It is a vermivorous species widely distributed along the West African coast in shallow water, but absent in Cabo Verde Archipelago. Historically it has received many names, which are all synonymized under the taxon $K$. pulcher. The name papilionaceus has been applied to small juveniles of $K$. pulcher, characterized by their brightly colored, well defined pattern. The taxon $K$. byssinus might represent a distinct species, or just a phenotypic northern variation of $K$. pulcher (see above). On the other hand, our mitogenomic analysis has revealed that the populations of pulcher-like individuals from the Canary Islands correspond to a separate species hereby introduced as $K$. canariensis sp. nov. (see above).

Kalloconus trochulus (Reeve, 1844)

Fig. 9F-H

Conus trochulus Reeve, 1844: pl. 45, sp. 246.

Conus atlanticoselvagem Afonso \& Tenorio, 2004: 34, figs 2-5.

Africonus cazalisoi Cossignani \& Fiadeiro, 2018a: 14. syn. nov.

Kalloconus stanchinensis Cossignani \& Fiadeiro, 2019b: 16. syn. nov.

Conus trochulus - Monteiro et al. 2004: 76, pl. 59.

Conus atlanticoselvagem - Monteiro et al. 2004: 26, pl. 63.

Conus pseudonivifer (not C. pseudonivifer Monteiro, Tenorio \& Poppe, 2004) - Monteiro et al. 2004: pl. 60 , figs $1-3,8$, pl. 61, figs $1-4$, pl. 62, figs $1-5,7$.

\section{Material examined}

Lectotype (here designated)

CABO VERDE • 26 mm; Boa Vista Island, Baía do Ervatão; 16²12'3" N, 2254'43" W; NHMUK 196179/1 (Fig. 9F).

Paralectotypes (here designated)

CABO VERDE $\bullet 2$ specs; same collection data as for lectotype; NHMUK 196179/2-3.

Three syntypes in NHMUK. We hereby designate as lectotype the specimen of dimensions $26 \times 16 \mathrm{~mm}$ in the type series (NHMUK 196179/1), which is the one figured in Reeve (1844: pl. 45, sp. 246) (Fig. 9F). The other two specimens in the same lot are designated as paralectotypes (NHMUK 196179/2-3). Type locality not known. Hereby designated as Baía do Ervatão, northwest coast of Boa Vista Island, Cabo Verde Archipelago.

\section{Other material}

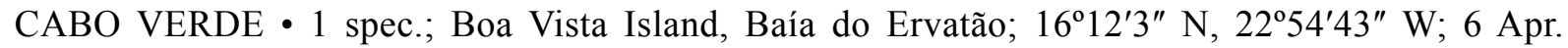
2014; MNCN exped.; GenBank mitochondrion, partial genome: MF491561; MNCN 15.05/80411 - 1 spec., $38 \mathrm{~mm}$, holotype of C. atlanticoselvagem; Baixo João Valente; 15 $44^{\prime} 27^{\prime \prime} \mathrm{N}, 23^{\circ} 5^{\prime} 26^{\prime \prime} \mathrm{W}$; ATLANTICO SELVAGEM exped.; MNCN 15.05/46580 (Fig. 9G) • 1 spec.; same collection data as for preceding; GenBank mitochondrion, partial genome: MF491606; MNCN DNA/7036 •

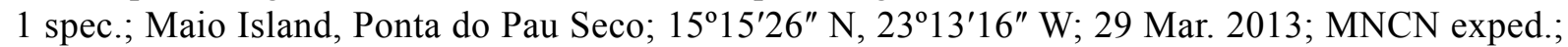
GenBank mitochondrion, partial genome: MF491519; MNCN 15.05/78635 • 1 spec.; Maio Island,

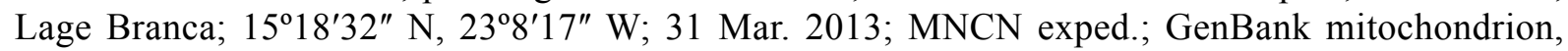




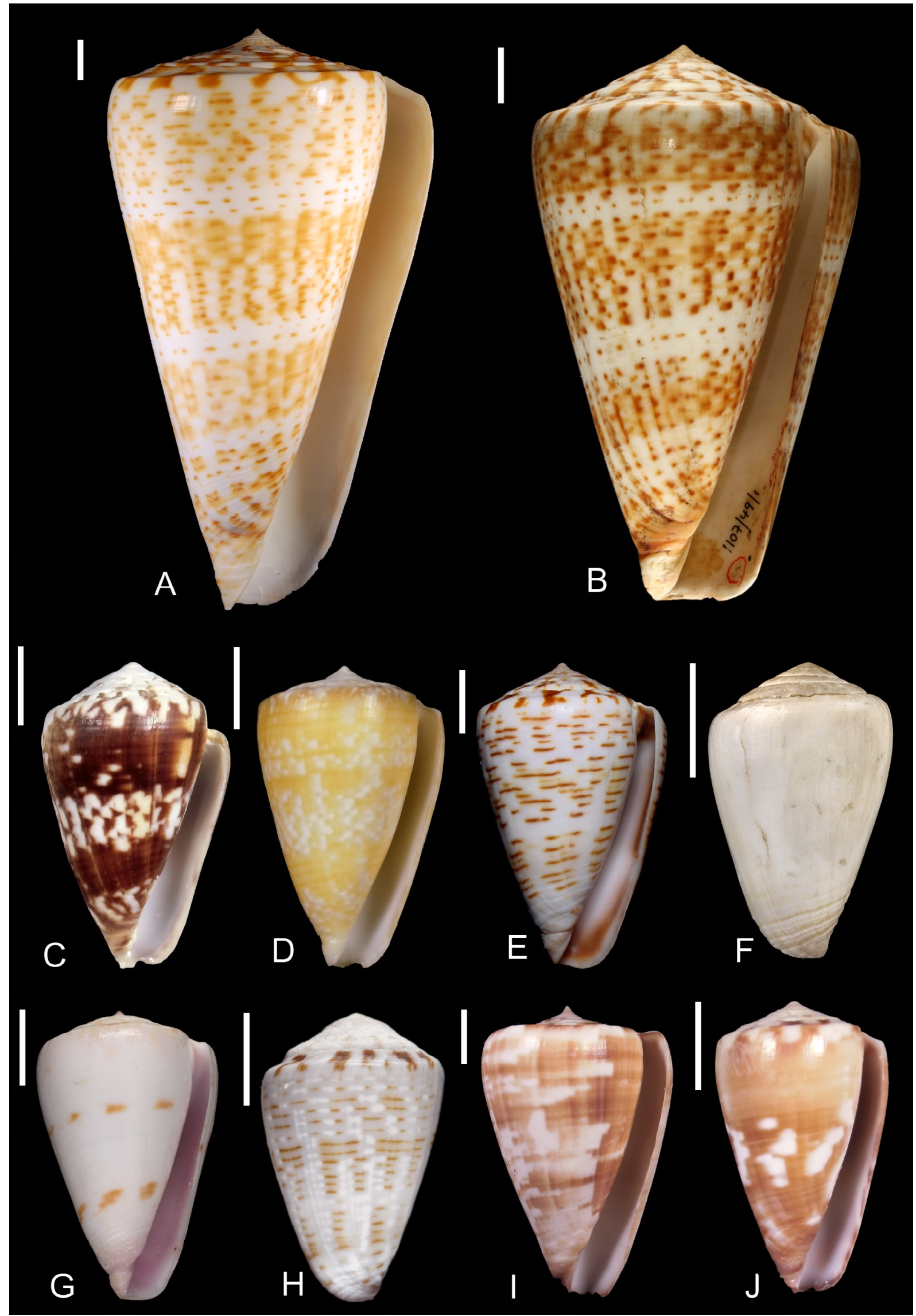


TENORIO M.J. et al., Taxonomic revision of West African cone snails

partial genome: MF491526; MNCN 15.05/78719 • 1 spec.; Maio Island, Porto Cais (north); $15^{\circ} 19^{\prime} 45^{\prime \prime} \mathrm{N}, 23^{\circ} 10^{\prime} 57^{\prime \prime} \mathrm{W} ; 1$ Apr. 2013; MNCN exped.; GenBank mitochondrion, partial genome: MF491532; MNCN 15.05/78779 • 1 spec.; Boa Vista Island, Estancinha, Ponta do Sol; $16^{\circ} 13^{\prime} 12^{\prime \prime} \mathrm{N}$, 22055'9" W; 2 Jul. 2013; MNCN exped.; GenBank mitochondrion, partial genome: KY864969; MNCN 15.05/80418 • $1 \mathrm{spec}$., $31.4 \mathrm{~mm}$; same collection data as for preceding; MNCN 15.05/88794 (Fig. 9H) 1 spec., $18 \mathrm{~mm}$, holotype of Africonus cazalisoi; Boa Vista Island, near the area of Morro de Areia; MMM • 1 spec., $28.1 \mathrm{~mm}$, holotype of Kalloconus stanchinensis; Boa Vista Island, Ponta do Sol, Rife do Stanchinha; MMM.

\section{Geographical distribution}

Boa Vista and Maio Islands, Cabo Verde Archipelago. Also present in Santiago Island, where it is very scarce.

\section{Conservation status in IUCN Red List}

Near threatened. Status revision required.

\section{Remarks}

Patternless- as well as patterned-shell forms of $K$. trochulus exist. The latter are widely distributed throughout the islands of Boa Vista, Maio, Santiago and offshore banks, and each of the existing populations has its own distinctive pattern. The name atlanticoselvagem was introduced for the offshore population inhabiting João Valente Bank in between the islands of Boa Vista and Maio (Fig. 9G). However, an analysis of the mitochondrial genome of patternless and patterned individuals from different populations recovered all of them within a compact clade, with the exception of two patterned individuals from Praia Canto, Boa Vista Island, which were recovered in a sister clade. These individuals are assigned to the taxon K. pseudonivifer (see above). Apart from this, the phylogenetic data suggest that all the other populations studied, both patterned and patternless, are members of one single, variable species that bears the name $K$. trochulus as the most senior. The hereby-designated lectotype of $K$. trochulus corresponds to the patternless form, particularly abundant in the northwest coast of Boa Vista Island. The recently described Africonus cazalisoi Cossignani \& Fiadeiro, 2018 was incorrectly assigned to the genus Africonus. It is a representative of the population of sparsely patterned $K$. trochulus from Morro de Areia, southwest of Boa Vista Island, which was thoroughly studied in Cunha et al. (2008), and hence another synonym for this species. The same applies to K. stanchinensis, which is just the patterned form of $K$. trochulus from Estancinha to Ponta do Sol area, northwest of Boa Vista Island (Fig. 9H). Representative individuals from the Santiago Island populations are figured in Rolán (2005).

Fig. 9. A. Kalloconus pulcher ([Lightfoot], 1786), $136 \mathrm{~mm}$ (MJT). B. Conus siamensis Hwass in Bruguière, 1792, lectotype, $102 \mathrm{~mm}$ (MHNG-MOLL-52702). C. Kalloconus marimaris Tenorio, Abalde \& Zardoya, 2018, holotype, $38.6 \mathrm{~mm}$ (MNCN 15.05/79664). D. Kalloconus marimaris, paratype, $36.6 \mathrm{~mm}$ (MNCN 15.05/79689). E. Conus pseudonivifer Monteiro, Tenorio \& Poppe, 2004, holotype, 47.4 mm (MNCN 15.05/46627). F. Conus trochulus Reeve, 1844, lectotype, $26 \mathrm{~mm}$ (NHMUK 196179/1). G. Conus atlanticoselvagem Afonso \& Tenorio, 2004 (= trochulus), holotype, $38.0 \mathrm{~mm}$ (MNCN 15.05/46580). H. Kalloconus trochulus f. stanchinensis Cossignani \& Fiadeiro, 2019, 31.4 mm (MNCN 15.05/88794). I. Kalloconus venulatus (Hwass in Bruguière, 1792), $52.4 \mathrm{~mm}$ (MNCN 15.05/80419). J. Kalloconus venulatus f. josefiadeiroi Cossignani \& Fiadeiro, 2019, $33.2 \mathrm{~mm}$ (MNCN 15.05/79907). Scale bars $=10 \mathrm{~mm}$. 
Kalloconus venulatus (Hwass in Bruguière, 1792)

Fig. 9I-J

Conus venulatus Hwass in Bruguière, 1792: 695.

Conus nivosus Lamarck, 1810: 278.

Conus quaestor Lamarck, 1810: 281.

Conus nivifer G.B. Sowerby I, 1833: pl. 25, fig. 14, pl. 36, fig. 47, pls 56-57, fig. 84.

Kalloconus (Trovaoconus) josefiadeiroi Cossignani \& Fiadeiro, 2019a: 30. syn. nov.

Conus venulatus - Monteiro et al. 2004: 80, pls 51, 53-58, pl. 52, figs 2, 4-5.

\section{Material examined}

\section{Lectotype}

Lectotype in MHNG 1107/69. The type locality 'America' (erroneous) is hereby corrected to Sal Rei, Boa Vista Island, Cabo Verde Archipelago.

\section{Other material}

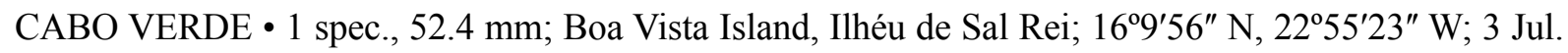
2013; MNCN exped.; GenBank mitochondrion, partial genome: KX263250; MNCN 15.05/80419 (Fig. 9I) • 1 spec., 33.2 mm; Boa Vista Island, Praia Canto; 16 $6^{\circ} 11^{\prime} 10^{\prime \prime} \mathrm{N}, 2^{\circ} 42^{\prime 2} 28^{\prime \prime} \mathrm{W} ; 20$ Apr. 2015; MNCN exped.; GenBank mitochondrion, partial genome: MF491590; MNCN 15.05/79907 (Fig. 9J) •

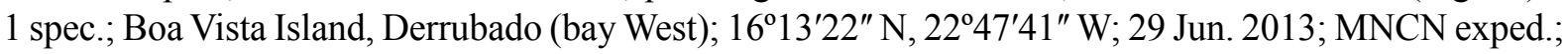
GenBank mitochondrion, partial genome: MF491546; MNCN 15.05/80396 • $1 \mathrm{spec}$.; Boa Vista Island, Ponta Antónia; 16²13'24" N, 22 46'59" W; 1 Jul. 2013; MNCN exped.; GenBank mitochondrion, partial genome: MF491560; MNCN 15.05/80410 • 1 spec.; Maio Island, Lage Branca; $15^{\circ} 18^{\prime} 32^{\prime \prime} \mathrm{N}, 23^{\circ} 8^{\prime} 17^{\prime \prime} \mathrm{W}$; 31 Mar. 2013; MNCN exped.; GenBank mitochondrion, partial genome: MF491531; MNCN 15.05/78774

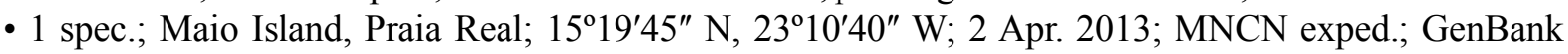
mitochondrion, partial genome: MF491535; MNCN 15.05/78812 - 1 spec.; Maio Island, Ponta do Pau Seco; $15^{\circ} 15^{\prime} 26^{\prime \prime}$ N, 23ำ $13^{\prime} 17^{\prime \prime} \mathrm{W}$; 3 Apr. 2013; MNCN exped.; GenBank mitochondrion, partial genome: MF491539; MNCN 15.05/78859 • 1 spec., 26.5 mm, holotype of Kalloconus (Trovaoconus) josefiadeiroi; Boa Vista Island, Praia do Canto-Baía das Gatas; 0.3-3 m depth; MMM.

\section{Geographical distribution}

Boa Vista and Maio islands, Cabo Verde Archipelago. Also present in Santiago Island, where it is very scarce.

\section{Conservation status in IUCN Red List}

Least concern.

\section{Remarks}

This is the largest-sized cone snail endemic to the Cabo Verde Archipelago, where it is widely distributed in Boa Vista and Maio islands. There are occasional reports of its presence off Santiago Island as well (Rolán 2005). Very variable in shell length and pattern, it has received a number of different names, which are all considered synonyms. Detailed populations genetic studies of the venulatus group (Cunha et al. 2008) and more recent mitogenomic phylogenetic analyses (Abalde et al. 2017a) indicate that despite the extreme phenotypic variability, all the populations scattered throughout the archipelago are members of one single species. This is also applicable to the recently introduced taxon K. josefiadeiroi, which is just a representative of the population of $K$. venulatus from Praia Canto, northeast coast of Boa Vista Island (Fig. 9J) and is included in our phylogenetic study. 


\section{Genus Monteiroconus Da Motta, 1991}

Monteiroconus ambiguus (Reeve, 1844)

Fig. 10A

Conus ambiguus Reeve, 1844: pl. 44, sp. 244.

Conus griseus Kiener, 1846: 114, pl. 63, fig. 2.

Conus miser Boivin, 1864: 39, pl. 1, fig. 9.

Conus gernanti Petuch, 1975b: 181, figs 2-6.

Conus ambiguus - Monteiro et al. 2004: 23, pl. 45, figs 1-4.

\section{Material examined}

Holotype (not examined)

The holotype was in the collection F.J. Stainforth, present whereabouts unknown; neotype in ZMA (Coomans et al. 1980). The original type locality was not known. For neotype: coast of Senegal, West Africa (Coomans et al. 1980).

\section{Neotype}

SENEGAL • 39.3 mm; coast of Senegal; NBC (Fig. 10A).

\section{Other material}

SENEGAL • 1 spec.; Mbour, Petite Côte; 30 m depth; MJT.

\section{Geographical distribution}

Senegal (south of Dakar), Gambia and northern Guinea Bissau.

\section{Conservation status in IUCN Red List}

Least concern.

\section{Remarks}

This species has not been molecularly examined, but the distinctive features of its shell and radula warrant its consideration as a valid species. The taxa names griseus and miser are considered synonyms of M. ambiguus, whereas gernanti represents a pale violet color form of this species without taxonomical value.

\section{Monteiroconus bellocqae (van Rossum, 1996)}

Fig. 10B

Conus bellocqae van Rossum, 1996: 59, figs 1-6.

Conus bellocqae - Monteiro et al. 2004: 28, pl. 45, figs 5-6.

\section{Material examined}

Holotype

GUINEA • 60.5 mm; off Conakry; 50-60 m depth; NBC.

\section{Paratype}

GUINEA • 1 spec., $60 \mathrm{~mm}$; same collection data as for holotype; F. Gubbioli coll., Marbella, Spain (Fig. 10B). 


\section{Geographical distribution}

Off Guinea Conakry.

\section{Conservation status in IUCN Red List}

Data deficient.

\section{Remarks}

This is a rare species, first obtained from fishing nets of trawlers operating in waters off Guinea Conakry in the 1980s. Since the fishing activities ceased, no more specimens have been brought to surface. Hence, it has not been molecularly examined. Its radular morphology is also unknown. The shell of this species is very similar to that of M. ambiguus, but it is characterized by the presence of numerous irregular reddish axial lines. It might represent just a mere patterned form of $M$. ambiguus from a particular geographic area. We hereby consider it as a provisionally valid species, pending future studies that might eventually validate its status as such, or alternatively demonstrate its conspecificity with M. ambiguus.

Monteiroconus tabidus (Reeve, 1844)

Fig. 10C

Conus tabidus Reeve, 1844: pl. 44, sp. 243.

Conus tabidus - Monteiro et al. 2004: 73, pl. 26.

\section{Material examined}

Holotype (not examined)

Holotype in ZMUC, GAS-000366. Since May 2012 the specimen is not present in the collection. The curator team was notified, but apparently the specimen has not been located hitherto. The type locality is not known.

\section{Other material}

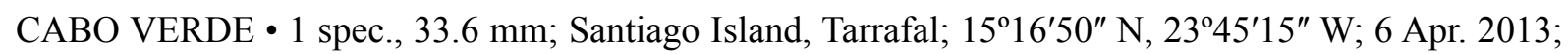
MNCN exped.; GenBank mitochondrion, partial genome: KY864968; MNCN 15.05/78863 (Fig. 10C).

\section{Geographical distribution}

West African coast from Senegal to Angola including Cabo Verde Archipelago and São Tomé e Príncipe.

\section{Conservation status in IUCN Red List}

Least concern.

\section{Remarks}

This is a fairly common, widespread species that has been molecularly examined as a representative of genus Monteiroconus. Historically, this species has been mistaken for M. ambiguus. However, there are constant features in shell morphology that allow a distinction between these two species, mainly the larger size and angulated, broader shoulder in the latter. In any case, a molecular examination of M. ambiguus might clarify whether the separation from M. tabidus at the species level is justified. We provisionally consider both of them as separate valid species. 
Genus Varioconus Da Motta, 1991

Da Motta (1991) originally introduced the taxon Varioconus as a subgenus of Conasprella Thiele, 1929 using the contour of the shell as criterion. The subgenus included West African species from Angola, Senegal and elsewhere, but not from the Cabo Verde Archipelago. Later, Tucker \& Tenorio (2009) elevated the rank of Varioconus to genus, and only maintained in it the endemic cones from Angola, whereas most of the remaining West African cones were placed in the genus Lautoconus. Now, we find that the reconstructed phylogeny and the observed genetic distances support the original proposal by $\mathrm{Da}$ Motta (1991), and the genus Varioconus actually includes species from Angola, Senegal, Gambia and other locations like Canary Islands or Saint Helena. The species of Varioconus endemic to Angola are not included in the present revision. These taxa are being sequenced systematically, and the results will be reported elsewhere in due course.

Varioconus belairensis (Pin \& Leung Tack in Pin, 1989a) comb. nov.

Fig. 10D

Conus belairensis Pin \& Leung Tack in Pin, 1989a: 33, pl. 1, figs 2-4, pl. 2A, figs 1-2.

Conus belairensis - Monteiro et al. 2004: 27, pl. 36.

\section{Material examined}

Holotype

SENEGAL • 36.7 mm; Pointe de Bel-Air, south coast of Dakar; MNHN IM-2000-32668 (Fig. 10D).

\section{Other material}

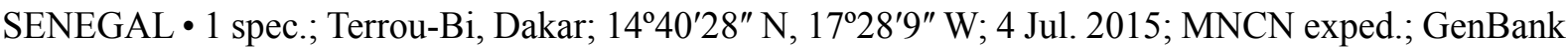
mitochondrion, partial genome: KY801849; MNCN 15.05/78504.

\section{Geographical distribution}

Dakar area including Madeleine Island, and to the south along the Petite Côte, Senegal.

\section{Conservation status in IUCN Red List}

Endangered. Status revision required.

\section{Remarks}

This is a valid, phenotypically variable species, which is closer to $V$. reticulatus than to $V$. mercator, both phylogenetically and according to its radular morphology (Abalde et al. 2017b). The distinction between $V$. belairensis and $V$. reticulatus based upon conchological or even radular features might not be effective in all cases. Whereas the original population from Bel-Air in Dakar seems to be extinct due to pollution from the large harbor of the city, the species occurs in many other locations around Dakar and to the south. As it happens with most species of cone snails living on the peninsula of Dakar, the individuals seem to have adapted very well to anthropogenic conditions, and populations thrive even in densely populated areas as long as they are not affected by chemical contamination, i.e., fuel from port activities.

Varioconus bruguieresi (Kiener, 1846) comb. nov.

Fig. 10E

Conus bruguieresi Kiener, 1846: pl. 56, fig. 2.

Conus bruguieri Kiener 1849: 221 (incorrect subsequent spelling).

Conus bruguieresi - Monteiro et al. 2004: 31, pl. 38. 


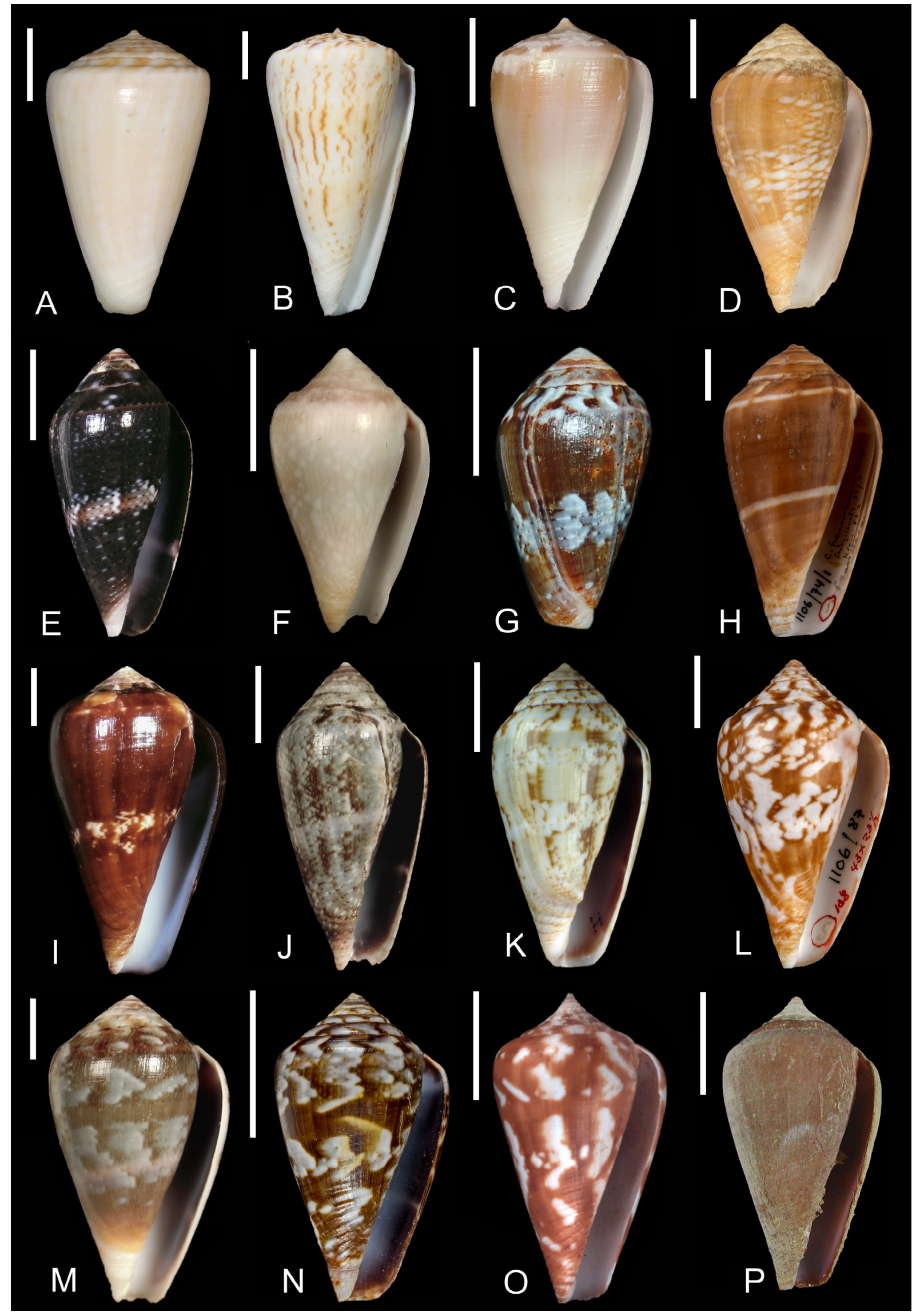


TENORIO M.J. et al., Taxonomic revision of West African cone snails

\section{Material examined}

Holotype (not examined)

The holotype was in the collection of Madame Dupont, its present whereabouts are unknown. The type locality was not stated, but was designated Dakar, Senegal by Coomans et al. (1982).

\section{Other material}

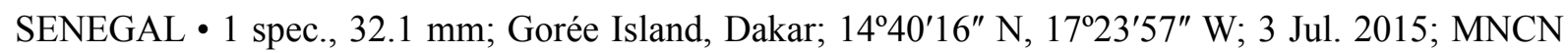
exped.; GenBank mitochondrion, partial genome: KY801852; MNCN 15.05/78497 (Fig. 10E) • 1 spec.; same collection data as for preceding; 3 Jul. 2015; MNCN exped.; GenBank mitochondrion, partial genome: KY801851; MNCN 15.05/78499 • 1 spec.; same collection data as for preceding; 3 Jul. 2015; MNCN exped.; GenBank mitochondrion, partial genome: KY801850; MNCN 15.05/78502.

\section{Geographical distribution}

Dakar area, Senegal.

\section{Conservation status in IUCN Red List}

Endangered.

\section{Remarks}

This species is characterized by its elongated greenish shell. The name Conus bruguieresi was originally published on plate 56, fig. 2 by Kiener, ahead of the text, which appeared published in 1849. In the text, the name used for this taxon was Conus bruguieri, which was a misspelling leading to subsequent misinterpretations in the literature (e.g., Wagner \& Abott 1978). Even though there was no description, the publication of the plate with a name (caption) on it is sufficient to make bruguieresi available as the earlier valid name for this taxon (Coomans et al. 1982; Faber 2011). Varioconus bruguieresi is very closely related to its sister species $V$. echinophilus, up to the point that juvenile individuals of the former can not be discriminated based upon conchological features only.

Varioconus cloveri (Walls, 1978) comb. nov.

Fig. 10F

Conus cloveri Walls, 1978: 2, pl. on p. 5.

Conus soaresi Trovão, 1978: 9, pl. 1, fig. 3-3b, pl. 2, fig. 1-1a.

Conus cloveri - Monteiro et al. 2004: 34, pl. 33.

Fig. 10 (opposite page). A. Conus ambiguus Reeve, 1844, neotype, $39.3 \mathrm{~mm}$ (NBC). B. Conus bellocqae van Rossum, 1996, paratype, $60 \mathrm{~mm}$ (F. Gubbioli coll., Marbella, Spain). C. Monteiroconus tabidus (Reeve, 1844), 33.6 mm (MNCN 15.05/78864). D. Conus belairensis Pin \& Leung Tack in Pin, 1989, holotype, 36.7 mm (MNHN IM-2000-32668). E. Varioconus bruguieresi (Kiener, 1846) comb. nov., $32.1 \mathrm{~mm}$ (MNCN 15.05/78497). F. Varioconus cloveri (Walls, 1978) comb. nov., $23.2 \mathrm{~mm}$ (MNCN 15.05/78457). G. Varioconus echinophilus (Petuch, 1975b) comb. nov., 22.0. mm (MNCN 15.05/90430). H. Conus franciscanus Hwass in Bruguière, 1792, lectotype, $56.6 \mathrm{~mm}$ (MHNG-MOLL-52625). I. Varioconus franciscanus (Hwass in Bruguière, 1792) comb. nov., $53.6 \mathrm{~mm}$ (MNCN 15.05/78491). J. Varioconus franciscanus f. hybridus (Kiener, 1847), $40.0 \mathrm{~mm}$ (MNCN 15.05/78427). K. Conus guanche Lauer, 1993, holotype, 34.0 mm (MNHN IM-2000-2553). L. Conus guinaicus Hwass in Bruguière, 1792, lectotype, $43.0 \mathrm{~mm}$ (MHNG-MOLL-52638). M. Varioconus guinaicus (Hwass in Bruguière, 1792) comb. nov., $50.2 \mathrm{~mm}$ (MNCN 15.05/78443). N. Lautoconus wolof Petuch \& Berschauer, 2018, holotype, 21.1 mm (MNHN IM-2000-34015). O. Conus pineaui Pin \& Leung Tack in Pin, 1989, holotype, $28.7 \mathrm{~mm}$ (MNHN IM-2000-2528). P. Conus dorotheae Monnier \& Limpalaër, 2010, holotype, $26.8 \mathrm{~mm}$ (MNHN IM-2009-8702). Scale bars $=10 \mathrm{~mm}$. 


\section{Material examined}

Holotype

SENEGAL • 25.7 mm; Dakar, harbor near Anse Bernard; DMNH 123128.

\section{Other material}

SENEGAL • 1 spec., 23.2 mm; Ndayane; 14³3'59" N, 1708'3" W; 2 Jul. 2015; MNCN exped.; GenBank mitochondrion, partial genome: KY801859; MNCN 15.05/78457 (Fig. 10F).

\section{Geographical distribution}

Dakar area and to the south along the Petite Côte, Senegal.

\section{Conservation status in IUCN Red List}

Endangered.

\section{Remarks}

The name soaresi for this taxon appeared published shortly after the description of Conus cloveri, which became the senior name for this species. This is a distinct species distributed from Pointe des Almadies to the south of Dakar along the Petite Côte. Two color forms exist, one with wavy brown narrow axial lines that overlap to produce fine tents on a creamy white background, and another one white, almost patternless with only faint traces of milky white axial lines. The latter seems to be more common at the southern end of the distribution range for the species. In the mitogenome phylogeny, $V$. cloveri is sister to $V$. mercator.

Varioconus dorotheae (Monnier \& Limpalaër, 2010) comb. nov.

Fig. 10P

Conus dorotheae Monnier \& Limpalaër, 2010: 73, pl. 1.

\section{Material examined}

\section{Holotype}

SENEGAL • 26.8 mm; Madeleine Island, west coast, Dakar; MNHN IM-2009-8702 (Fig. 10P).

\section{Geographical distribution}

Known only from the type locality.

\section{Conservation status in IUCN Red List}

Near threatened.

\section{Remarks}

The mitogenome is not available, as we have not examined this taxon. However, partial sequences of coxl, rrnL and $r r n S$ genes were reported (Puillandre et al. 2014). In the corresponding phylogeny, $V$. dorotheae appeared closely related to $V$. pineaui (a synonym of $V$. guinaicus) and $V$. guanche (Puillandre et al. 2014). Radular morphology also confirms its placement in the V. guinaicus group. Given its geographically restricted habitat on the west coast of Madeleine Island in relatively deep water (between 10 and $15 \mathrm{~m}$ ) (Monnier \& Limpalaër 2010), we retain this taxon as provisionally valid in spite of its close phylogenetic relationship to V. guinaicus. Examination of its mitogenome in the future might confirm this assumption, or alternatively prove otherwise. 
Varioconus echinophilus (Petuch, 1975) comb. nov.

Fig. 10G

Conus echinophilus Petuch, 1975b: 180, figs 1-3, 7.

Conus echinophilus - Monteiro et al. 2004: 41, pl. 37.

\section{Material examined}

Holotype (not examined)

The holotype is in CAS with catalog number 55454 according to the original publication. However, Coomans et al. (1986) stated that one of the paratypes (CAS 61495, $10.7 \times 6.0 \mathrm{~mm}$ ) was deposited instead of the holotype, which was still missing in 1988 (Filmer 2011). Current whereabouts of the holotype are unknown.

\section{Paratype}

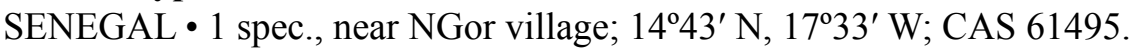

\section{Other material}

SENEGAL • 1 spec., 22.0 mm; south of Dakar, Petite Côte, Yenne Tode; L. Tamagnini leg.; GenBank mitochondrion, partial genome: MT240807; MNCN 15.05/90430 (Fig. 10G).

\section{Geographical distribution}

Dakar area, Senegal.

\section{Conservation status in IUCN Red List}

Endangered.

\section{Remarks}

This is a species very closely related to $V$. bruguieresi. In fact, in a previous phylogenetic analysis (Abalde et al. 2017a), the mitogenome of one juvenile specimen initially identified as $V$. cf. echinophilus turned out to be identical in sequence to that of $V$. bruguieresi. However, the mitogenome of another specimen of $V$. echinophilus sequenced here was recovered as sister to that of $V$. bruguieresi, at a genetic distance consistent with a valid species (Fig. 2).

Varioconus franciscanus (Hwass in Bruguière, 1792) comb. nov.

Fig. $10 \mathrm{H}-\mathrm{J}$

Conus franciscanus Hwass in Bruguière, 1792: 698.

Conus hybridus Kiener, 1847: 256, pl. 83, fig. 1. syn. nov.

Conus hybridus - Monteiro et al. 2004: 52, pl. 39.

\section{Material examined}

Lectotype

“AFRICA”• 56.6 mm; MHNG-MOLL-52625 (Fig. 10H).

\section{Other material}

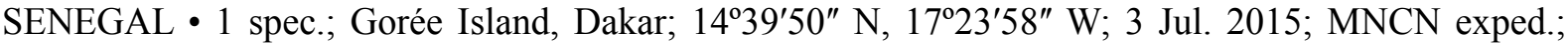
GenBank mitochondrion, partial genome: KY801853; MNCN 15.05/79496 • 1 spec., 53.6 mm; same 
collection data as for preceding; MNCN 15.05/78491 (Fig. 10I) • 1 spec., $40.0 \mathrm{~mm}$; Dakar, NGor; $14^{\circ} 45^{\prime} 6^{\prime \prime} \mathrm{N}, 17^{\circ} 30^{\prime} 3^{\prime \prime} \mathrm{W} ; 1$ Jul. 2015; MNCN exped.; GenBank mitochondrion, partial genome: KY801863; MNCN 15.05/78427 (Fig. 10J).

\section{Geographical distribution}

Dakar area, Senegal.

\section{Conservation status in IUCN Red List}

Endangered (evaluated as hybridus).

\section{Remarks}

The lectotype of the taxon Conus franciscanus Hwass in Bruguière, 1792 designated by Kohn (1968) is at the MNHG. It measures $56.6 \mathrm{~mm}$ (stated $55 \mathrm{~mm}$ in Kohn 1968). It has been a controversial species, and several authors have synonymized this name either with Conus ventricosus Gmelin, 1791 (Kohn 1992) or Conus guinaicus Hwass in Bruguière, 1792 (Röckel 1989; Lauer 1993b; Filmer 2011). The homonym name franciscanus (variety mediterraneus Hwass) Philippi, 1836 applicable to a color form of ventricosus further contributed to increase the confusion. The type locality ("Africa") and the size and general appearance of the lectotype of franciscanus are more consistent with a guinaicuslike species than with the Mediterranean L. ventricosus. In this sense, we agree with the opinions of Röckel (1989) and Lauer (1993b), also followed by Filmer (2011) and Tucker \& Tenorio (2013). Specimens matching the lectotype of $V$. franciscanus are relatively abundant around Gorée Island in Dakar. These uniform dark brown shells with a white central band had provisionally been assigned to the taxon $V$. guinaicus, despite being lighter and more elongated than the typical form of the latter species (Monteiro et al. 2004). We examined the mitogenome of one of such dark guinaicus-like specimens from Gorée Island. It showed almost no sequence divergence with a specimen of $V$. hybridus from NGor. This result was confirmed by sequencing of the universal coxl gene fragment (Folmer et al. 1994) of additional guinaicus-like specimens from Gorée Island (Abalde et al. 2017b). Typical V. guinaicus from Popenguine are recovered as the sister clade. These results indicate that the guinaicus-like specimens from Gorée Island, representatives of the taxon $V$. franciscanus, are essentially identical to $V$. hybridus, and different from typical $V$. guinaicus. If we assume the conspecificity of the taxa franciscanus Hwass in Bruguière, 1792 and hybridus Kiener, 1847, then the latter becomes a junior synonym to represent a form of franciscanus, which stands as the senior name for the species.

Varioconus guanche (Lauer, 1993) comb. nov.

Fig. 10K

Conus guanche Lauer, 1993a: 37, figs 3-5.

Conus guanche nitens Lauer, 1993a: 39, figs 6-8.

Lautoconus saharicus Petuch \& Berschauer, 2016: 95, fig. 2.

Conus guanche - Monteiro et al. 2004: 50, pls 8-13.

\section{Material examined}

Holotype

SPAIN - Canary Islands • 34 mm; Tenerife, Punta Blanca, Los Gigantes; MNHN IM-2000-2553 (Fig. 10K) 
TENORIO M.J. et al., Taxonomic revision of West African cone snails

\section{Other material}

SPAIN - Canary Islands • 1 spec.; Lanzarote, Playa del Cable; 16 $41^{\prime} 44^{\prime \prime}$ N, 22 $2^{\circ} 58^{\prime} 35^{\prime \prime}$ W; Apr. 2014; MNCN exped.; GenBank mitochondrion, partial genome: KY801847; MNCN/ADN 91295.

\section{Geographical distribution}

Canary Islands (absent in the western islands), southern Morocco, West Sahara and Mauritania.

\section{Conservation status in IUCN Red List}

Least concern.

\section{Remarks}

Until its introduction as a new species by Lauer (1993a), there was a large confusion regarding certain populations of cones present in the Canary Islands, referred to as ventricosus, guinaicus or desidiosus (Bandel \& Wils 1977; Coomans et al. 1985b; Raybaudi 1992). The taxon Lautoconus desidiosus (A. Adams, 1853) is nowadays considered a form of L. ventricosus (Filmer 2011) or a separate species (Monteiro et al. 2004; WoRMS, accessed March 2020) depending on the author, but in any case is restricted to the Mediterranean Sea and neighboring Atlantic and is not a West African species. In the phylogeny, V. guanche appears deeply nested within the Varioconus clade together with Senegal endemics and is only distantly related to L. ventricosus. It is indeed sister to the species $V$. unifasciatus, and close to V. guinaicus (Abalde et al. 2017b). The non-planktonic development of $V$. guanche supposedly limits its capacity of dispersal, resulting in populations having characteristic shell colors and patterns. However, phylogenetic studies focused on $V$. guanche showed no differentiation of the species within the Canary Islands or between the archipelago and the western African coast indicating recurrent gene flow (Cunha et al. 2014). These findings clearly indicate that the recently introduced taxon Lautoconus saharicus Petuch \& Berschauer, 2016 represents the local form of $V$. guanche from Dahkla Bay, Western Sahara. It lacks taxonomical value and must be considered a junior synonym. The name nitens, initially introduced as a subspecies of $V$. guanche, is applied to high-spired shells typically from Lanzarote. However, typical $V$. guanche and high-spired individuals co-occur, hence the separation at subspecific level seems unjustified and nitens represents a synonym (form) of $V$. guanche.

Varioconus guinaicus (Hwass in Bruguière, 1792) comb. nov.

Fig. 10L-P

Conus guinaicus Hwass in Bruguière, 1792: 697.

Conus adansonii Lamarck, 1810: 424.

Conus taslei Kiener, 1850: 360, pl. 110, fig. 3.

Conus luridus A. Adams, 1854: 118.

Conus pineaui Pin \& Leung Tack in Pin, 1989b: 66, figs 17, 32, 38.

Lautoconus wolof Petuch \& Berschauer, 2018: 169, figs 3D-F. syn. nov.

Conus guinaicus - Monteiro et al. 2004: 51, pls 40-42.

Conus taslei-Monteiro et al. 2004: 73, pl. 44.

Conus pineaui - Monteiro et al. 2004: 65, pl. 43.

\section{Material examined}

Lectotype

“GUINEA" • 43 mm; MHNG-MOLL-52638 (Fig. 10L). 


\section{Other material}

SENEGAL • 1 spec., 50.2 mm; Ndayane, Petite Côte; 14³3'59" N, 17 ${ }^{\circ} 8^{\prime \prime} 3^{\prime \prime}$ W; 2 Jul. 2015; MNCN exped.; GenBank mitochondrion, partial genome: KY801861; MNCN 15.05/78443 (Fig. 10M) • 1 spec.; Fann, Terrou-Bi, Dakar; 1440'28' N, 17²8'9" W; 4 Jul. 2015; MNCN exped.; GenBank mitochondrion, partial genome: KY801848; MNCN 15.05/78511 • 1 spec.; Joal-Fadiouth; $14^{\circ} 8^{\prime 2} 20^{\prime \prime} \mathrm{N}, 16^{\circ} 48^{\prime} 57^{\prime \prime} \mathrm{W}$; 2 Jul. 2015; MNCN exped.; GenBank mitochondrion, partial genome: KY801855; MNCN 15.05/78476 - 1 spec.; Ndayane, Petite Côte; 2016; L. Tamagnini leg.; GenBank mitochondrion, partial genome: MT240805; MNCN 15.05/78541 1 spec., 28.7 mm, holotype of $C$. pineaui; Cap de Naze, Popenguine, south of Dakar; 20-30 m depth; MNHN IM-2000-2528 (Fig. 10O).

GAMBIA - 1 spec., $21.1 \mathrm{~mm}$, holotype of Lautoconus wolof; off Tanji Beach; MNHN IM-20002528 (Fig. 10N) • 1 spec.; same locality as for holotype; 19 Feb. 2019; L. Tamagnini leg.; GenBank mitochondrion, partial genome: MT240811; MNCN 15.05/90434.

\section{Geographical distribution}

Senegal, Gambia, Guinea-Bissau, and Guinea. Also reported from Ghana.

\section{Conservation status in IUCN Red List}

Vulnerable. Status revision required.

\section{Remarks}

This is the most representative taxon of a very compact clade, which includes a number of very closely related species, and certain populations with minimal differences in mitogenome sequences that are now considered synonyms (forms), such as taslei or pineaui (Fig. 10O). All these taxa share the same radular tooth morphology: narrow and elongated radular tooth with the anterior section longer than the posterior section, rounded blade covering less than half of the anterior section, and more than 40 denticles in the serration (Abalde et al. 2017b). The population from Gorée Island, characterized by its dark brown shell, does not correspond to the taxon guinaicus but to its sister species $V$. franciscanus. The distribution range of $V$. guinaicus is quite large, from Dakar area south to Guinea including Gambia, and also reported from Ghana. The taxon $V$. wolof (Fig. 10N), recently described from Gambia, has been sequenced. The sequence of its mitogenome is essentially identical to that of $V$. guinaicus (Fig. 2). Therefore, this name represents a mere local form of $V$. guinaicus and is hereby considered a synonym.

Varioconus mercator (Linnaeus, 1758) comb. nov. Fig. $11 \mathrm{~A}-\mathrm{G}$

Conus mercator Linnaeus, 1758: 750.

Cucullus aurelius Röding, 1798: 47.

Conus lamarckii Kiener, 1847: 240, pl. 83, fig. 4.

Conus orri Ninomiya \& da Motta in da Motta, 1982: 15, fig. 14. syn. nov.

Conus cacao Ferrario, 1983: 146.

Lautoconus senegalensis Gulden et al., 2017: 49, figs 1-5.

Lautoconus fernandi Petuch \& Berschauer, 2018: 166, figs 2a-b. syn. nov.

Lautoconus gambiensis Petuch \& Berschauer, 2018: 167, figs 2c-e. syn. nov.

Lautoconus rikae Petuch \& Berschauer, 2018: 169, figs 3a-c. syn. nov.

Lautoconus stimpsonorum Cossignani \& Allary, 2019: 23. syn. nov.

Conus mercator - Monteiro et al. 2004: 58, pls 27-28.

Conus cacao - Monteiro et al. 2004: 32, pl. 34. 
TENORIO M.J. et al., Taxonomic revision of West African cone snails

\section{Material examined}

\section{Lectotype}

Lectotype at LSL 254 (Fig. 11A, 24.0 mm). Type locality not known.

\section{Other material}

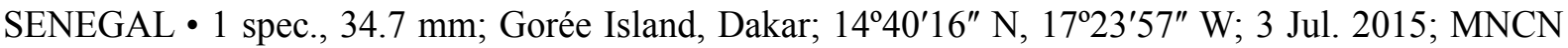
exped.; GenBank mitochondrion, partial genome: KY801854; MNCN 15.05/78482 (Fig.11B) • 1 spec.;

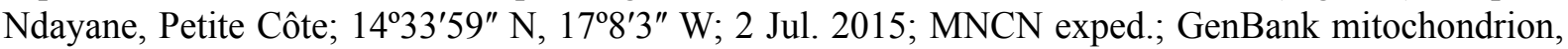
partial genome: KY801857; MNCN 15.05/78463 • 1 spec.; same locality as for preceding; 2 Jul. 2015; MNCN exped.; GenBank mitochondrion, partial genome: KY801856; MNCN 15.05/78473 • 1 spec.,

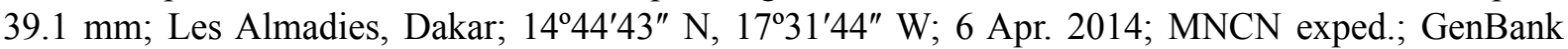
mitochondrion, partial genome: KY801864; MNCN 15.05/78419 (Fig. 11C) • 1 spec., 35.5 mm, holotype of Lautoconus stimpsonorum; Pointe des Almadies, Dakar; 3-8 m depth; MNHN.

GAMBIA - 1 spec., $35.4 \mathrm{~mm}$, holotype of Lautoconus fernandi; off Tanji beach; MNHN IM-200034012 (Fig. 11D) • 1 spec.; same collection data as for preceding; 19 Feb. 2019; L. Tamagnini leg.; GenBank mitochondrion, partial genome: MT240813; MNCN 15.05/90440 - 1 spec., $21.6 \mathrm{~mm}$, holotype of Lautoconus gambiensis; off Tanji beach; MNHN IM-2000-34013 (Fig. 11E) • 1 spec.; same collection data as for preceding; 19 Feb. 2019; L. Tamagnini leg.; GenBank mitochondrion, partial genome: MT240812; MNCN 15.05/90437 • 1 spec., 17.9 mm, holotype of Lautoconus rikae; off Tanji beach; MNHN IM-2000-34014 (Fig. 11F) • 1 spec.; same collection data as for preceding; 19 Feb. 2019; L. Tamagnini leg.; GenBank mitochondrion, partial genome: MT240814; MNCN 15.05/90442 • 1 spec., 30.1 mm, paratype of Conus orri; Bojol Island, Soliflor Point; SNMS ZI0091234 (Fig. 11G).

\section{Geographical distribution}

Senegal (Dakar area, Petite Côte) and Gambia.

\section{Conservation status in IUCN Red List}

Endangered. Status revision required.

\section{Remarks}

This is one of the most classical species from Senegal. Specimens from Gorée Island (Fig. 11B) match perfectly the lectotype of this species (Fig. 11A), which is widely distributed from Dakar area to the south. This is a polymorphic species. Several taxon names introduced in the literature as distinct species (e.g., cacao and senegalensis) correspond to the taxon V. mercator. Abalde et al. (2017b) showed that two different morphs identified as V. mercator, one from Goreé Island (Fig. 11B) and another from Pointe des Almadies (Fig. 11C), were actually separated by a genetic uncorrected $p$ distance at exactly the threshold that delimits species. Based upon these grounds, the name $V$. stimpsonorum has been recently introduced for the population of mercator-like shells from Pointe des Almadies (Cossignani \& Allary 2019). However, the subtle differences in the reticulated shell pattern (coarse in $V$. stimpsonorum but fine in $V$. mercator) do not justify the introduction of a new name. Furthermore, a transcriptomic study of the venom gland of two specimens of $V$. mercator, one from Almadies (i.e., form stimpsonorum) and another from Ndayane (form cacao), has shown that both individuals share a significant percentage of conotoxin precursors in their venom repertoires within the expected intraspecific variation (Abalde et al. 2020). Therefore, we consider that the taxon V. stimpsonorum falls within the genetic and morphological variability of $V$. mercator and propose to consider it a mere form of the latter. Specimens of the species recently described from Gambia, including fernandi (Fig. 11D), gambiensis (Fig. 11E) and rikae (Fig. 11F), have been sequenced. The sequences of the mitogenomes of these taxa were almost identical, and showed a minimal divergence to that of $V$. mercator (Fig. 2). 
The type material of the taxon Conus orri Ninomiya \& da Motta, 1982 (Fig. 11G) described from Gambia is consistent with the observed variability of $V$. mercator. We therefore also consider orri as a synonym of the latter.

Conversely, a mitogenome examination has shown that certain names traditionally synonymized with V. mercator (e.g., reticulatus) actually correspond to separate, valid species (see below). As it happens to most species living around the Dakar peninsula, V. mercator seems to be very resilient and has adapted very well to environments under heavy human influence as long as they are not affected by chemical or industrial contamination.

Varioconus reticulatus (Born, 1778) comb. nov.

Fig. $11 \mathrm{H}-\mathrm{I}$

Conus reticulatus Born, 1778: 139.

Conus mercator (not C. mercator Linnaeus, 1758) - Monteiro et al. 2004: pls 29-32.

\section{Material examined}

Lectotype

“AFRICA”• 25 mm; NHMW Mollusca 14159 (Fig. 11H).

\section{Other material}

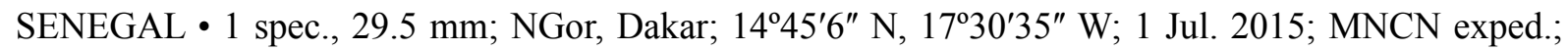
GenBank mitochondrion, partial genome: KY801862; MNCN 15.05/78439 (Fig. 11I) - 1 spec.;

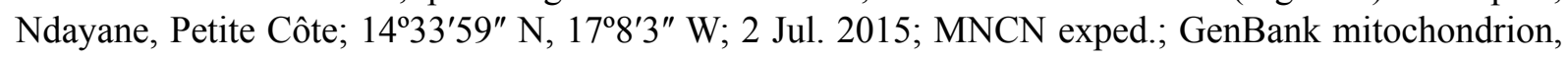
partial genome: KY801858; MNCN 15.05/78462.

\section{Geographical distribution}

Senegal (Dakar area, Petite Côte).

\section{Conservation status in IUCN Red List}

Not evaluated.

\section{Remarks}

The taxon Conus reticulatus Born, 1778 had been traditionally synonymized with Conus mercator Linnaeus, 1758 (Monteiro et al. 2004; Filmer 2011; Tucker \& Tenorio 2013). The phylogenetic analyses suggest that $V$. reticulatus actually is a valid species, distinct from $V$. mercator and sister to $V$. belairensis (Abalde et al. 2017b). Varioconus mercator and V. reticulatus also differ in radular tooth morphology. A separation of $V$. reticulatus and $V$. mercator based upon the shell pattern only is not always accurate, and may eventually require confirmation by DNA or radular morphology analysis. Specimens collected along Petite Côte near Ndayane and initially identified as juveniles of $V$. mercator form cacao turned out to be $V$. reticulatus.

Varioconus tacomae (Boyer \& Pelorce, 2009) comb. nov.

Fig. 11J

Conus tacomae Boyer \& Pelorce, 2009: 26, figs 9-12. 


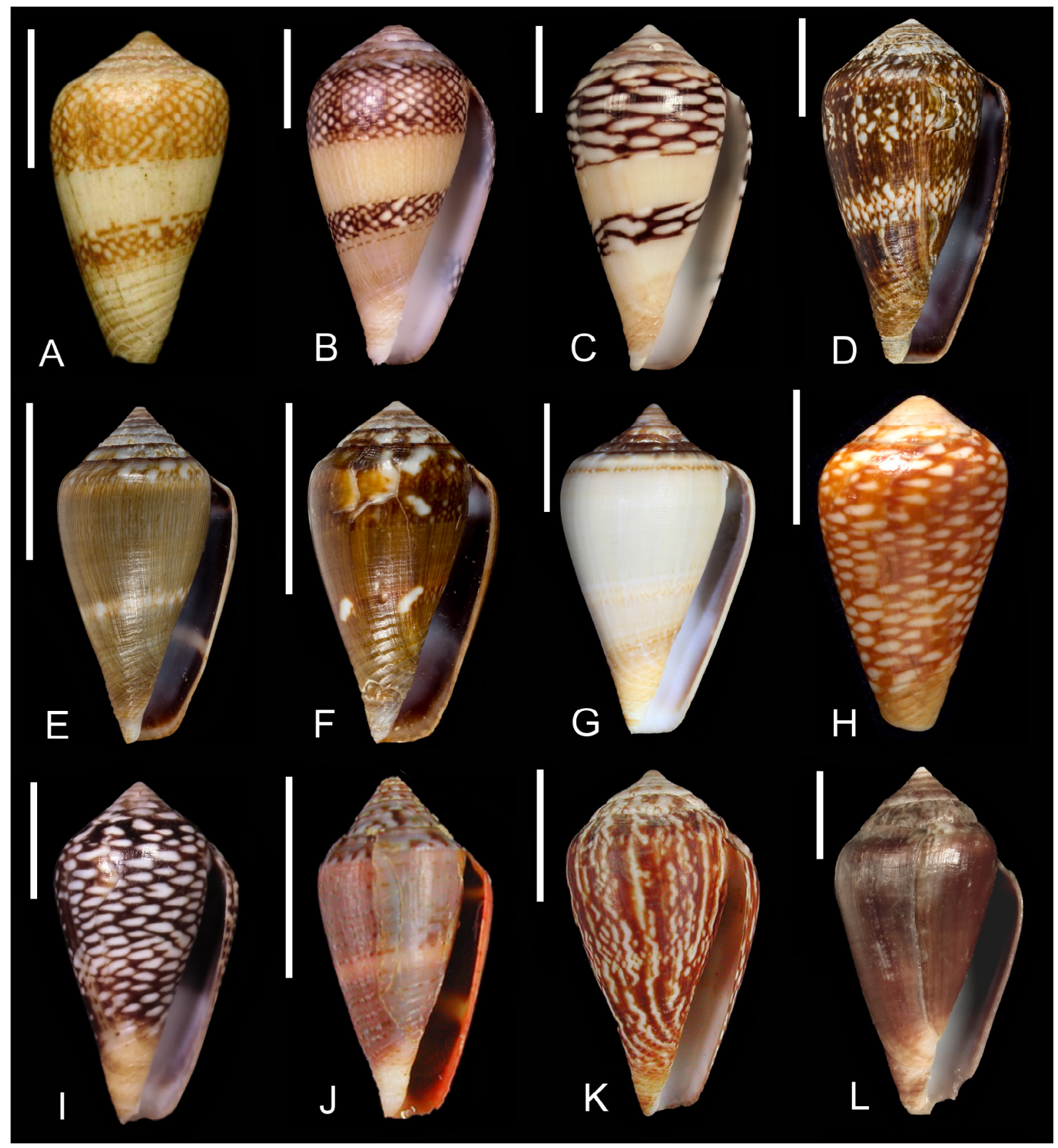

Fig. 11. A. Conus mercator Linnaeus, 1758, lectotype, $24.0 \mathrm{~mm}$ (LSL 254). B. Varioconus mercator (Linnaeus, 1758) comb. nov., $34.7 \mathrm{~mm}$ (MNCN 15.05/78482). C. Varioconus mercator f. stimpsonorum (Cossignani \& Allary, 2019), $39.1 \mathrm{~mm}$ (MNCN 15.05/78419). D. Lautoconus fernandi Petuch \& Berschauer, 2018, holotype, 35.4 mm (MNHN IM-2000-34012). E. Lautoconus gambiensis Petuch \& Berschauer, 2018, holotype, $21.6 \mathrm{~mm}$ (MNHN IM-2000-34013). F. Lautoconus rikae Petuch \& Berschauer, 2018, holotype, $17.9 \mathrm{~mm}$ (MNHN IM-2000-34014). G. Conus orri (Ninomiya \& da Motta, 1982), paratype, $30.1 \mathrm{~mm}$ (SNMS ZI0091234). H. Conus reticulatus Born, 1778, lectotype, $25 \mathrm{~mm}$ (NHMW Mollusca 14159). I. Varioconus reticulatus (Born, 1778) comb. nov., $29.5 \mathrm{~mm}$ (MNCN 15.05/78439). J. Conus tacomae Boyer \& Pelorce, 2009, holotype, 17 mm (MNHN IM-200021046). K. Conus trencarti Nolf \& Verstraeten, 2008, holotype, $26.3 \mathrm{~mm}$ (MNHN IM-2000-21455). L. Varioconus unifasciatus (Kiener, 1850) comb. nov., $39.8 \mathrm{~mm}$ (MNCN 15.05/78451). Scale bars $=$ $10 \mathrm{~mm}$. 


\section{Material examined}

\section{Holotype}

SENEGAL • 17 mm; East of Gorée Island, 'Tacoma' wreck; 7-13 m depth; MNHN IM-2000-21046 (Fig. 11J).

\section{Geographical distribution}

Dakar area, Senegal.

\section{Conservation status in IUCN Red List}

Vulnerable.

\section{Remarks}

This species has not been molecularly examined. In the original description it was compared to Conus desidiosus (which does not live in Senegal), bruguieresi and echinophilus. The species is morphologically related to the latter two, and might represent a variation of one of these. We consider this species as provisionally valid only, pending future molecular examination.

Varioconus trencarti (Nolf \& Verstraeten, 2008) comb. nov.

Fig. $11 \mathrm{~K}$

Conus trencarti Nolf \& Verstraeten, 2008: 1, pls 1-2.

\section{Material examined}

Holotype

SENEGAL • 26.3 mm; Pointe des Almadies; 20 m depth; MNHN IM-2000-21455 (Fig. 11K).

\section{Other material}

SENEGAL - 1 spec.; Pointe des Almadies; A. Trencart leg.; GenBank mitochondrion, partial genome: MT240815; MNCN 15.05/90433.

\section{Geographical distribution}

Dakar area, Senegal.

\section{Conservation status in IUCN Red List}

Near threatened.

\section{Remarks}

This is another member of the $V$. guinaicus clade, with a close phenotypical resemblance to $V$. guinaicus form pineaui. The sequence divergence of the mitogenome of one individual from the type locality suggests that this is a valid species, sister to $V$. guanche and $V$. unifasciatus (Fig. 2). At variance with most other species of Varioconus from Senegal, $V$. trencarti has a relatively deep-water habitat, between 20 and $40 \mathrm{~m}$, and a restricted distribution range around Pointe des Almadies, Dakar.

\section{Varioconus unifasciatus (Kiener, 1850) comb. nov.}

Fig. 11L

Conus unifasciatus Kiener, 1850: 61, pl. 110, fig. 4.

Conus unifasciatus - Monteiro et al. 2004: 77, pl. 35. 
TENORIO M.J. et al., Taxonomic revision of West African cone snails

\section{Material examined}

Holotype

Holotype at MNHN, IM-2000-3454. Type locality not known.

\section{Other material}

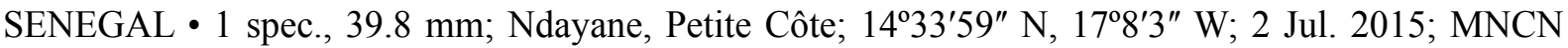
exped.; GenBank mitochondrion, partial genome: KY801860; MNCN 15.05/78451 (Fig. 11L).

\section{Geographical distribution \\ South of Dakar, Petite Côte area, Senegal.}

\section{Conservation status in IUCN Red List}

Endangered.

\section{Remarks}

This species is sister to $V$. guanche, and is characterized by its uniform dark brown shell, with the occasional presence of lighter-colored spiral bands just as in the holotype. It has been synonymized with V. franciscanus in Petuch \& Berschauer (2016). However, according to the phylogeny, the latter is a distinct, valid species sister to $V$. guinaicus. In any case, the guinaicus clade is very compact, and all its members are closely related to each other.

\section{Discussion}

In the present work, we have reviewed in detail the species of cone snails from West Africa, excluding the endemics from Angola. The analysis of almost complete mitogenome sequences for 131 individuals has proved to be of utmost importance in the reconstruction of robust phylogenetic trees, which were used as an evolutionary framework to revise the taxonomy of these gastropods (Abalde et al. 2017a, 2017b; this work). As of December 2019, 178 species names for West African cone snails have been introduced, taking into consideration the revision by Monteiro et al. (2004) as a starting point. After the present revision, 100 species are considered valid or provisionally valid. Additionally, two new species have been introduced herein, elevating the total number of species to 102 (Figs 1, 12). This number represents most likely an overestimation, as it still provisionally considers valid all the endemic species from Angola listed in Monteiro et al. (2004) plus all the species described from this area since then (a total of 35 species). The phylogeny of Angolan cone snails is currently under study, and results will be reported in due course. Hence, about $40 \%$ of the named species from the West African region are considered invalid, as they constitute junior synonyms describing particular color forms of other polymorphic species, indicating that shell colors and patterns are prone to convergence, and hence rather homoplasious (Fig. 12). In the case of the endemic cones from the Cabo Verde Archipelago, the number is reduced from 108 named species (100 Africonus +8 Kalloconus) to a total of 48 valid or provisionally valid species (43 Africonus +5 Kalloconus). This indicates that less than one half of the names introduced for Cabo Verde endemic species of cones correspond to at least provisionally valid species. The main reason for this huge taxonomic inflation comes most likely from the rapid publication of taxa names in amateur magazines addressed to shell collectors, without proper peer review and based exclusively on shell material (actually only a minimum part of these species turned out to be valid). However, even in the studies in which several independent traits have been taken into consideration (i.e., animal features, radular morphology, egg capsules, or even coxl gene fragment sequencing), the very close phylogenetic proximity among the different taxa have made the delimitation of species very hard. The same applies for many cone species recently described from other areas of West Africa, such as Senegal or Gambia. In these areas, the shell pattern or distribution range represent traits that in most cases are not reliable enough as proxies for species separation, unless proven otherwise by discriminant molecular 

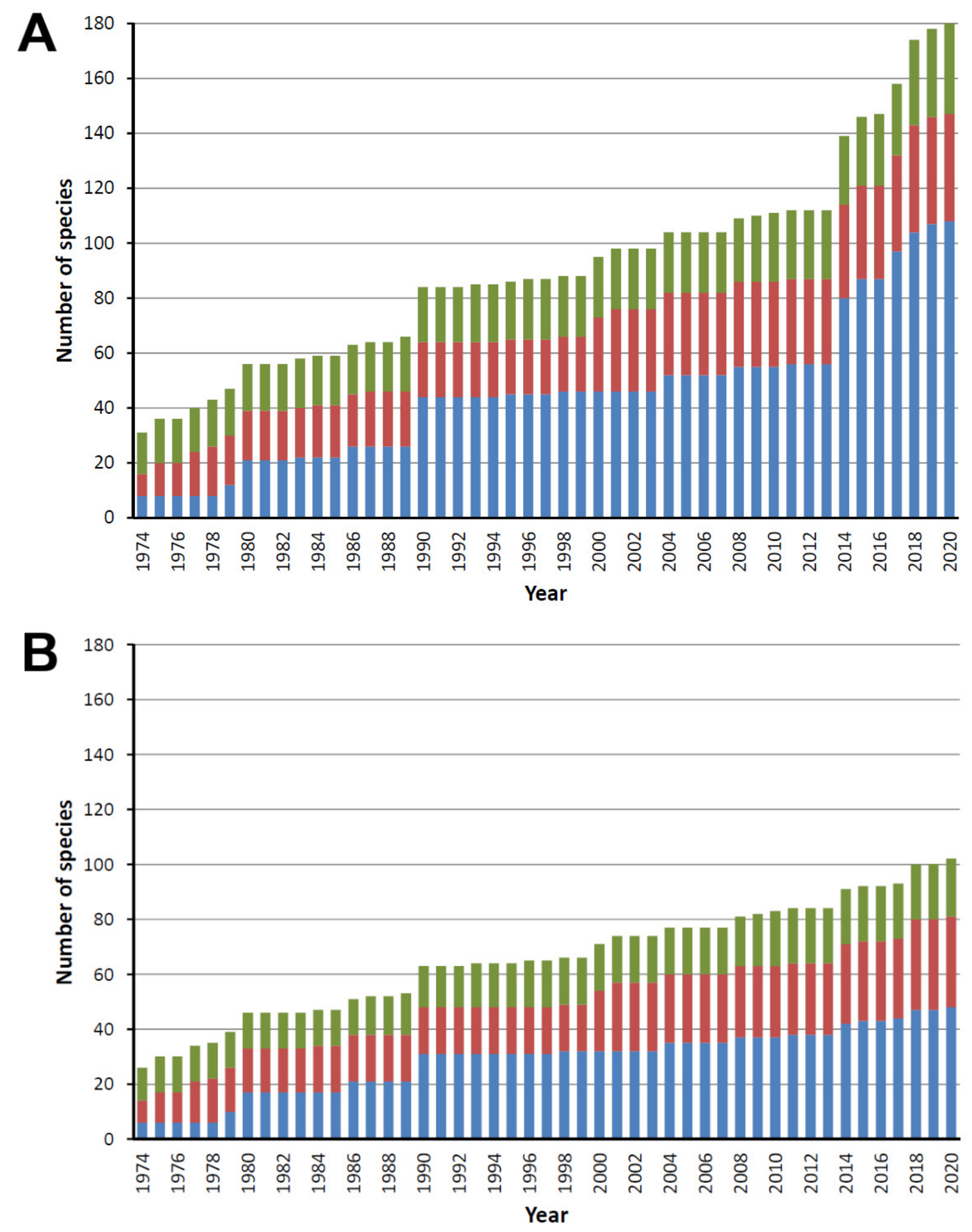

\section{Cabo Verde endemics angola endemics West Africa}

Fig. 12. Stacked bar charts of the accumulated number of species described in the period 1974-2020 before (A) and after (B) revision, showing the contribution to the total number of species of the Cabo Verde endemics (blue), Angola endemics (red) and the remaining species from West Africa (green). Note that Angolan cone endemics still await a thorough genetic revision. 
A

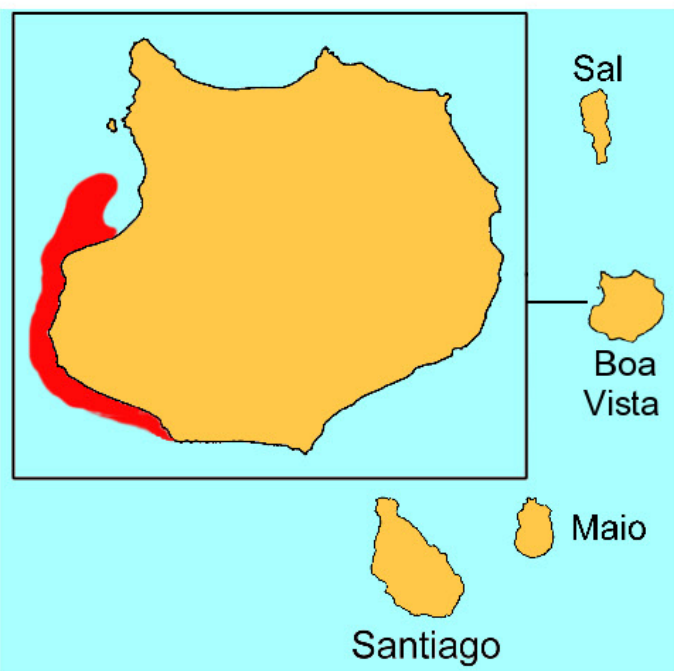

A. crotchii

B

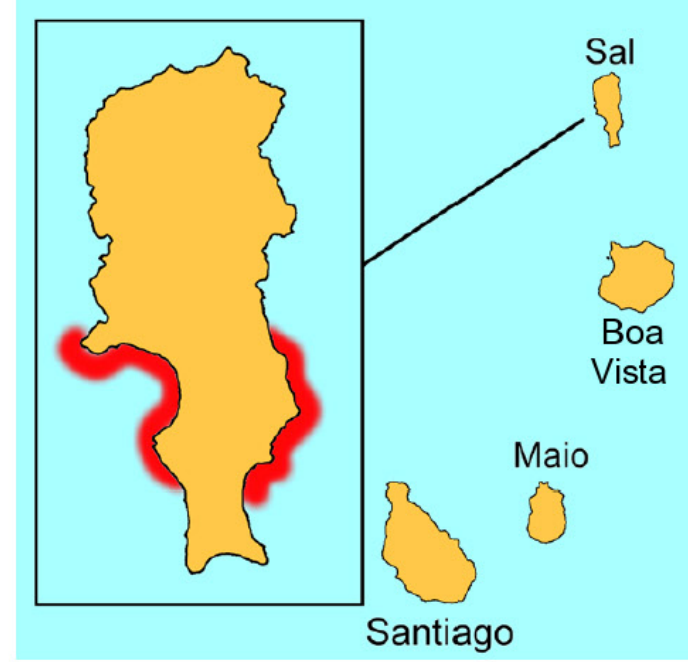

K. ateralbus
After

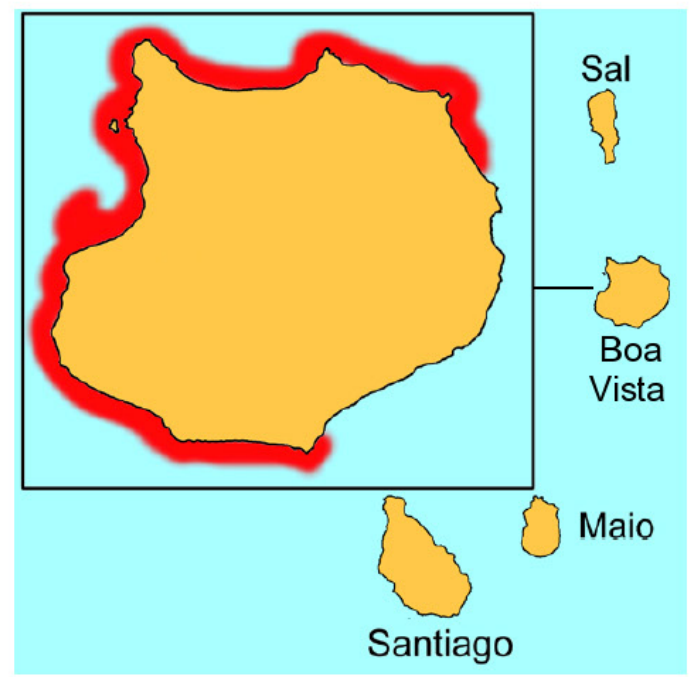

A. crotchii

\section{After}

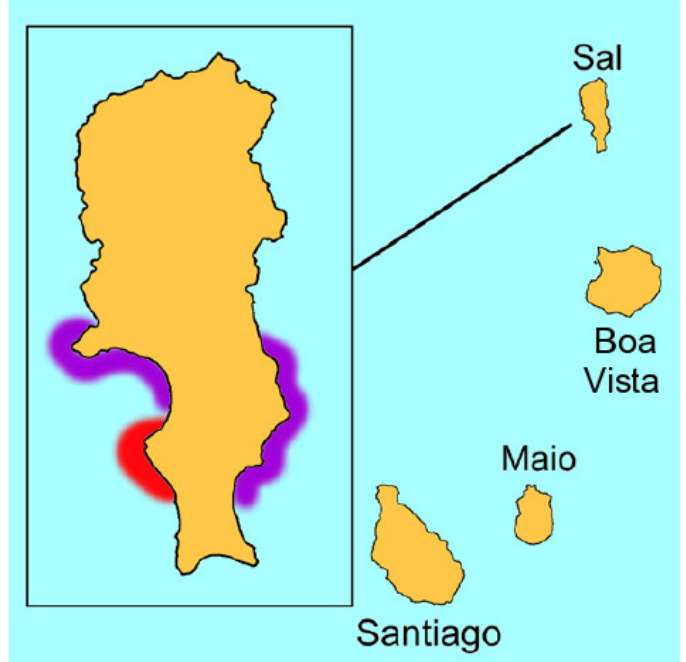

K. ateralbus

K. marimaris

Fig. 13. Changes in distribution affecting Red List status due to the updated classification of cone snails from West Africa. A. The case of Africonus crotchii (Reeve, 1849) as an example of an increase in range distribution, and thus an estimated decrease on its risk status. B. The case of Kalloconus ateralbus (Kiener, 1850) as an example of a decrease in range distribution, and thus an estimated increase on its risk status. 
(i.e., mitogenomes and ideally sets of nuclear markers to detect potential instances of hybridization or incomplete lineage sorting) methods. Hence, we strongly suggest that new taxa names for cone snails from West Africa based upon shell characters only and not supported additionally by robust molecular studies in the original descriptions should be treated with utmost caution. In spite of meeting the ICZN criteria to be accepted as available names, their status as valid species should be put on hold by the scientific community until proper confirmation, in order to avoid unnecessary taxonomic inflation. It is interesting to note that the accumulated number of valid or provisionally valid species follows a lineal trend $\left(\mathrm{R}^{2}=0.9855\right)$ since the year 1974 , with a slope value of 1.5 . This means that during this period only 1-2 valid species have been discovered per year on average in the West African region. Over time, this rate will most likely be reduced, as the number of species is not expected to grow indefinitely.

The drastic reduction of the number of valid species results in important changes affecting the distribution ranges of many of these taxa. In most cases, distribution ranges are extended due to synonymy, but in several instances they are very much reduced due to the discovery of cryptic species. One of the former cases corresponds to $A$. crotchii, which was restricted to the southeast coast of Boa Vista Island but now is found to be widely distributed on the island (Fig. 13A). One of the latter cases corresponds to the taxon K. ateralbus, endemic to Sal Island in Cabo Verde. It was classified as 'endangered' in the IUCN Red List (Tenorio 2012), but now its distribution range (southwest of Sal Island) appears much more restricted than initially considered due to the assignment of some of its populations to K. marimaris (Fig. 13B). Therefore, a new assessment of the risk status of this species using the new information hereby provided will likely result in an upgrade of its Red List category (Peters et al. 2016). Likewise, studies on ecology and biogeography relying on the inventory of cone snail species from eastern Atlantic areas (i.e., Freitas et al. 2019) should take into consideration the results of the present work. This has been the case of the estimation of speciation rates for Cabo Verde cone snails that varied considerably when taking into consideration the number of valid species based on genetic criteria (Phuong et al. 2019). We are currently extending our mitogenome sequencing approach to address the phylogenetic relationships of cones from Angola as well as from the Mediterranean and nearby eastern Atlantic region. Results will be reported in due course, and the conclusions will undoubtedly have an effect on the figures of the cone snail fauna diversity in these regions.

\section{Acknowledgements}

We thank three anonymous reviewers for their insightful comments on a previous version of the manuscript. We are indebted to Cabo Verde biology students Paulo Vasconcelos and Stiven Pires, as well as to our colleagues Carlos M.L. Afonso, Sara Rocha, Sereina Rutschmann, David Posada and Julio Rozas for their valuable help during sampling in Cabo Verde. We thank Dr Rui Freitas from the Universidade de Cabo Verde (UniCV) for his continuous support and for granting us access to the facilities of the UniCV in Mindelo, São Vicente. We also thank Dr Iderlindo Silva dos Santos and Dra Sonia Monteiro de Pina Araujo from the Direcçao Nacional do Medio Ambiente of the Ministério do Ambiente, Habitação e Ordenamento do Território (MAHOT) of the Republic of Cabo Verde for their help with collecting permits (Autorizações 07/2013, 26/2013, 01/2104, 04/2015 and 03/2016). We are indebted to Amadou Gaye, Pier Luigi Tamagnini and Alex Trencart in Senegal, to Francisco Sicilia (Lanzarote), Rafael Mesa (Lanzarote), Ricardo Vega (Tenerife) and Jonay García Melián (Las Palmas de Gran Canaria) in the Canary Islands, and to Gavin Malcolm and the late Chris Schönherr in Angola for their valuable help during sampling. We are grateful to Jesús Marco and Aida Palacios, who provided access to the supercomputer Altamira at the Institute of Physics of Cantabria (IFCA-CSIC), member of the Spanish Supercomputing Network, for performing assembling and phylogenetic analyses. We also wish to thank Virginie Héros and Manuel Caballer (MNHN, Paris, France), Andreia Salvador and Harry Taylor (NHMUK, London, UK), Emmanuel Tardy and Philippe Wagneur (MHNG, Geneve, Switzerland), Anita Eschner and A. Schumacher (NHMW, Vienna, Austria), Ira Richling (SNMS, Stuttgart, Germany) and 
TENORIO M.J. et al., Taxonomic revision of West African cone snails

the Linnean Society of London for the photos of type material hosted at their respective institutions. This work was supported by the Spanish Ministry of Science and Innovation, Spain (CGL2013-45211-C2-2-P and CGL2016-75255-C2-1-P to RZ; BES-2014-069575 to SA; BES-2017-081195 to JRPB).

\section{References}

Abalde S., Tenorio M.J., Afonso C.M.L., Uribe J.E., Echeverry A.M. \& Zardoya R. 2017a. Phylogenetic relationships of cone snails endemic to Cabo Verde based on mitochondrial genomes. BMC Evolutionary Biology 17: 231. https://doi.org/10.1186/s12862-017-1069-x

Abalde S., Tenorio M.J., Afonso C.M.L. \& Zardoya R. 2017b. Mitogenomic phylogeny of cone snails endemic to Senegal. Molecular Phylogenetics and Evolution 112: 79-87.

https://doi.org/10.1016/j.ympev.2017.04.020

Abalde S., Tenorio M.J., Afonso C.M.L. \& Zardoya R. 2018. Conotoxin diversity in Chelyconus ermineus (Born, 1778) and the convergent origin of piscivory in the Atlantic and Indo-Pacific cones. Genome Biology and Evolution 10 (10): 2643-2662. https://doi.org/10.1093/gbe/evy150

Abalde S., Tenorio M.J., Uribe J.E. \& Zardoya R. 2019. Conidae phylogenomics and evolution. Zoologica Scripta 48: 194-214. https://doi.org/10.1111/zsc.12329

Abalde S., Tenorio M.J., Afonso C.M.L. \& Zardoya R. 2020. Comparative transcriptomics of the venoms of continental and insular radiations of West African cone snails. In press.

https://doi.org/10.1098/rspb.2020.0794

Adams A. 1854. Descriptions of new species of the genus Conus, from the collection of Hugh Cuming, Esq. Proceedings of the Zoological Society of London 1854: 116-119. Available from http://biology.burke.washington.edu/conus/catalogue/sources/Adams,\%20A.,\%201854.\%20Proc.\%20 Zool.\%20Soc.\%20Lond..pdf [accessed 29 Mar. 2020].

Afonso C.M.L. \& Tenorio M.J. 2004. Description of a new offshore species of Conus from the Cape Verde Archipelago (Gastropoda, Conidae). La Conchiglia: International Shell Magazine 36 (310): 3340.

Afonso C.M.L. \& Tenorio M.J. 2011. A new, distinct endemic Africonus species (Gastropoda, Conidae) from São Vicente Island, Cape Verde Archipelago, West Africa. Gloria Maris 50 (5):125136. Available from

https://storage.googleapis.com/conchology-general-images/images/gloriamaris/pdfs/2011/Vol50-5.pdf [accessed 23 May 2020]

Afonso C.M.L. \& Tenorio M.J. 2014. Recent findings from the islands of Maio and Boa Vista in the Cape Verde Archipelago, West Africa: description of three new Africonus species (Gastropoda: Conidae). Xenophora Taxonomy 3: 47-60.

Bandel K. \& Wils E. 1977. On Conus mediterraneus and Conus guinaicus. Basteria 41: 33-45. Available from http://natuurtijdschriften.nl/download?type=document;docid=596671 [accessed 29 Mar. 2020].

Barros e Cunha J.G. 1933. Catálogo descritivo das conchas exóticas da colecção António Augusto de Carvalho Monteiro Família Conidae. Memórias e Estudos do Museu Zoológico da Universidade de Coimbra sér. 1 71: 1-224.

Bettocchi M. 2018. Genuanoconus genuanus (Linnaeus, 1758): a species very variable in pattern and profile. The Cone Collector 31: 6-36. Available from http://theconecollector.com/lib/docs/tcc_31.pdf.zip [accessed 29 Mar. 2020].

Boivin A. 1864. Description de cinq espèces nouvelles du genre Conus. Journal de Conchyliologie 12: 33-40. 
Borges L.M.S., Hollatz C., Lobo J., Cunha A.M., Vilela A.P., Calado G., Coelho R., Costa A.C., Ferreira M.S.G., Costa M.H. \& Costa F.O. 2016. With a little help from DNA barcoding: investigating the diversity of Gastropoda from the Portuguese coast. Scientific Reports 6: 20226-20226. https://doi.org/10.1038/srep20226

Born I. von 1778. Index Rerum Naturalium Musei Caesarei Vindobonensis. Pars Prima, Testacea. Available from http://biology.burke.washington.edu/conus/catalogue/sources/Born,\%20I.,\%20 1778.\%20\%20Index\%20Rerum\%20Naturalium.pdf [accessed 29 Mar. 2020].

Boyer F. \& Pelorce J. 2009. Description d'un nouveau Conus (Gastropoda: Conidae) du Sénégal dans le groupe Conus mediterraneus. Novapex 10 (1): 25-32. Available from

https://www.biodiversitylibrary.org/page/42270880 [accessed 29 Mar. 2020].

Burnay L.P. \& Monteiro A.A. 1977. Seashells from Cape Verde Islands. Published by the authors, Lisbon.

Bruguière J.G. 1792. Cone. In: Encyclopédie méthodique: Histoire naturelle des Vers 1: 586-757. Panckouke, Paris. https://doi.org/10.5962/bhl.title.49857

Chernomor O., von Haeseler A. \& Minh B.Q. 2016. Terrace aware data structure for phylogenomic inference from supermatrices. Systematic Biology 65: 997-1008. https://doi.org/10.1093/sysbio/syw037

Clench W.J. 1942. The genus Conus in the western Atlantic. Johnsonia 1 (6): 1-40.

Coomans H.E., Moolenbeek R.G. \& Wils E. 1980. Alphabetical revision of the (sub)species in recent Conidae 3. albus to antillarum with the description of Conus algoensis agulhasi, nov. subspecies. Basteria 44 (1/4): 17-49. Available from http://natuurtijdschriften.nl/download?type=document\&docid=596716 [accessed 29 Mar. 2020].

Coomans H.E., Moolenbeek R.G. \& Wils E. 1981. Alphabetical revision of the (sub)species in recent Conidae 4. aphrodite to azona with the description of Conus arenatus bizona nov. subspecies. Basteria 45 (1/3): 3-55. Available from http://natuurtijdschriften.nl/download?type=document\&docid=596730 [accessed 29 Mar. 2020].

Coomans H.E., Moolenbeek R.G. \& Wils E. 1982. Alphabetical revision of the (sub)species in recent Conidae 5. baccatus to byssinus, including Conus brettinghami nomen novum. Basteria 46 (1/4): 3-67. Available from http://natuurtijdschriften.nl/download?type=document\&docid=596751 [accessed 29 Mar. 2020].

Coomans H.E., Moolenbeek R.G. \& Wils E. 1985a. Alphabetical revision of the (sub)species in recent Conidae 7. cingulatus to cylindraceus, including Conus shikamai nomen novum. Basteria 48 (6): 223 311. Available from http://natuurtijdschriften.nl/download?type=document\&docid=596791 [accessed 29 Mar. 2020].

Coomans H.E., Moolenbeek R.G. \& Wils E. 1985b. Alphabetical revision of the (sub)species in recent Conidae 8. dactylosus to dux. Basteria 49 (4/6): 145-196. Available from http://natuurtijdschriften.nl/download?type=document\&docid=596813 [accessed 29 Mar. 2020].

Coomans H.E., Moolenbeek R.G. \& Wils E. 1986. Alphabetical revision of the (sub)species in recent Conidae 9. ebraeus to extraordinarius with the description of Conus elegans ramalhoi nov. subspecies. Basteria 50 (4/6): 93-150. Available from

http://natuurtijdschriften.nl/download?type=document\&docid=596828 [accessed 7 Apr. 2020].

Cossignani T. 2014. Dieci nuovi coni da Capo Verde. Malacologia Mostra Mondiale 82 (1): 18-29.

Cossignani T. \& Allary A. 2019. Lautoconus (Lautoconus) stimpsonorum: nuova specie dal Senegal. Malacologia Mostra Mondiale 104: 21-23. 
TENORIO M.J. et al., Taxonomic revision of West African cone snails

Cossignani T. \& Fiadeiro R. 2014a. Quattro nuovi coni da Capo Verde. Malacologia Mostra Mondiale 83 (2): 14-19.

Cossignani T. \& Fiadeiro R. 2014b. Cinque nuovi coni da Capo Verde. Malacologia Mostra Mondiale 84 (3): 21-27.

Cossignani T. \& Fiadeiro R. 2015a. Tre nuovi coni da Capo Verde. Malacologia Mostra Mondiale 86: $17-21$.

Cossignani T. \& Fiadeiro R. 2015b. Due Nuovi Coni da Capo Verde. Malacologia Mostra Mondiale 87: $3-5$.

Cossignani T. \& Fiadeiro R. 2015c. Due Nuovi Coni da Capo Verde. Malacologia Mostra Mondiale 88: $3-5$.

Cossignani T. \& Fiadeiro R. 2017a. Otto nuovi coni da Capo Verde. Malacologia Mostra Mondiale 94: 26-36.

Cossignani T. \& Fiadeiro R. 2017b. Un nuovo cono da Capo Verde. Malacologia Mostra Mondiale 96: $32-34$.

Cossignani T. \& Fiadeiro R. 2017c. Un nuovo cono da Capo Verde. Malacologia Mostra Mondiale 97: $52-53$.

Cossignani T. \& Fiadeiro R. 2018a. Quattro nuovi coni da Capo Verde. Malacologia Mostra Mondiale 98: 14-20.

Cossignani T. \& Fiadeiro R. 2018b. Africonus perrineae: un nuovo cono da Capo Verde. Malacologia Mostra Mondiale 99: 17-19.

Cossignani T. \& Fiadeiro R. 2018c. Africonus tarafensis: un nuovo cono da Capo Verde. Malacologia Mostra Mondiale 101: 32-34.

Cossignani T. \& Fiadeiro R. 2019a. Kalloconus (Trovaoconus) josefiadeiroi un nuovo cono da Capo Verde. Malacologia Mostra Mondiale 102: 30-32.

Cossignani T. \& Fiadeiro R. 2019b. Un nuovo cono da Capo Verde. Malacologia Mostra Mondiale 104: $16-17$.

Cunha R.L., Castilho R., Rüber L. \& Zardoya R. 2005. Patterns of cladogenesis in the venomous marine gastropod genus Conus from the Cabo Verde Archipelago. Systematic Biology 54: 634-650. https://doi.org/10.1080/106351591007471

Cunha R.L., Tenorio M.J., Afonso C., Castilho R. \& Zardoya R. 2008. Replaying the tape: recurring biogeographical patterns in Cabo Verde Conus after 12 million years. Molecular Ecology 17: 885-901. https://doi.org/10.1111/j.1365-294X.2007.03618.x

Cunha R.L., Grande C. \& Zardoya R. 2009. Neogastropod phylogenetic relationships based on entire mitochondrial genomes. BMC Evolutionary Biology 9: 210. https://doi.org/10.1186/1471-2148-9-210

Cunha R.L., Lima F.P., Tenorio M.J., Ramos A.A., Castilho R. \& Williams S.T. 2014. Evolution at a different pace: distinctive phylogenetic patterns of cone snails from two ancient oceanic archipelagos. Systematic Biology 63: 971-987. https://doi.org/10.1093/sysbio/syu059

da Motta A.J. 1982. Seventeen new cone shell names (Gastropoda: Conidae). Publicações Ocasionais da Sociedade Portuguesa de Malacologia 1: 1-20.

da Motta A.J. 1991. A Systematic Classification of the Gastropod Family Conidae at the Generic Level. La Conchiglia, Rome. 
Dillwyn L.W. 1817. A Descriptive Catalogue of Recent Shells, Arranged According to the Linnean Method; with Particular Attention to the Synonymy, vol. 1. J. and A. Arch, London. Available from http://biology.burke.washington.edu/conus/catalogue/sources/Dillwyn,\%20L.W.,\%201817.\%20 Descr.\%20Cat.\%20Rec.\%20Shells,\%20i..pdf [accessed 29 Mar. 2020].

Duda T.F. \& Rolán E. 2005. Explosive radiation of Cabo Verde Conus, a marine species flock. Molecular Ecology 14: 267-272. https://doi.org/10.1111/j.1365-294X.2004.02397.x

Duda T.F., Kohn A.J. \& Palumbi S.R. 2001. Origins of diverse feeding ecologies within Conus, a genus of venomous marine gastropods. Biological Journal of the Linnean Society 73: 391-409.

https://doi.org/10.1006/bij1.2001.0544

Echterbille J., Gilles N., Araóz R., Mourier G., Amar M., Servent D., De Pauw E. \& Quinton L. 2017. Discovery and characterization of $\mathrm{EII}_{\mathrm{B}}$, a new $\alpha$-conotoxin from Conus ermineus venom by nAChRs affinity capture monitored by MALDI-TOF/TOF mass spectrometry. Toxicon 130: 1-10. https://doi.org/10.1016/j.toxicon.2017.02.023

Elsen J. 1983. Taxonomy of some Cape Verde Conidae with description of a novel species. Informations de la Société belge de Malacologie 11: 180-189.

Faber M. 2011. The holy grail of Louis Charles Kiener's "Spécies général des coquilles vivantes". Miscellanea Malacologica 5 (3): 61-70. Available from

http://olivirv.myspecies.info/sites/olivirv.myspecies.info/files/The $\% 20$ holy $\% 20$ grail $\% 20$ of $\% 20$ Louis\%20Charles\%20-\%20Faber\%2C\%20M.J_.pdf [accessed 29 Mar. 2020].

Ferrario M. 1983. La Piu' Grande Enciclopedia delle Conchiglie di Tutto il Mondo. Alberto Peruzzi, Milan.

Filmer R.M. 2011. Nomenclature and Taxonomy in Living Conidae, $1^{\text {st }}$ Ed. Available from http://www.theconecollector.com/filmer/index.html [accessed 29 Mar. 2020].

Fischer von Waldheim G. 1807. Museum - Demidoff, ou Catalogue systématique et raisonné des Curiosités de la Nature et de l'Art, données à l'Université impériale de Moscou par son Excellence Monsieur Paul de Demidoff. Tome Troisième. Moscow. https://doi.org/10.5962/bhl.title.160942

Folmer O., Black M., Hoeh W., Lutz R. \& Vrijenhoek R. 1994. DNA primers for amplification of mitochondrial cytochrome c oxidase subunit I from diverse metazoan invertebrates. Molecular Marine Biology and Biotechnology 3: 294-299.

Freitas R., Romeiras M., Silva L., Cordeiro R., Madeira P., González J.A., Wirtz P., Falcón J.M., Brito A., Floeter S.R., Afonso P., Porteiro F., Viera-Rodríguez M.A., Neto A.I., Haroun R., Farminhão J.N.M., Rebelo A.C., Baptista L., Melo C.S., Martínez A., Núñez J., Berning B., Johnson M.E. \& Ávila S.P. 2019. Restructuring of the "Macaronesia" biogeographic unit: a marine multi-taxon biogeographical approach. Scientific Reports 9: 15792. https://doi.org/10.1038/s41598-019-51786-6

Gmelin J.F. 1791. Caroli a Linné. Systema Naturae per Regna Tria Naturae: secundum classes, ordines, genera, species, cum characteribus, differentiis, synonymis, locis, $13^{\text {th }}$ Ed. Vol. 1. Impensis Georg. Emanuel. Beer, Leipzig [Lipsiae]. https://doi.org/10.5962/bhl.title.36932

Grande C., Templado J. \& Zardoya R. 2008. Evolution of gastropod mitochondrial genome arrangements. BMC Evolutionary Biology 8: 61. https://doi.org/10.1186/1471-2148-8-61

Gulden G.J., Moolenbeek R.G. \& Goud J. 2017. A new Lautoconus (Gastropoda: Conidae) from Senegal. Miscellanea Malacologica 7 (3): 49-53.

Kiener L.C. 1845-1859. Genre Cone. (Conus, Lin.) Spécies général et iconographie des coquilles vivantes comprenant la collection du Muséum d'Histoire naturelle de Paris, collection Lamarck, celle 
TENORIO M.J. et al., Taxonomic revision of West African cone snails

du Prince Masséna et les découverts récente des voyageurs. Rousseau, Paris [pp. 1-64, 1846; 65-176, 1847 ; 177-224, 1848; 225-272, 1859; 273-379, 1849-50; plates 1-111, 1845].

https://doi.org/10.5962/bhl.title.39135

Kohn A.J. 1963. Type specimens and identity of the described species of Conus. I. The species described by Linnaeus, 1758-1767. Journal of the Linnean Society of London, Zoology 44 (302): 740-768.

https://doi.org/10.1111/j.1096-3642.1963.tb01641.x

Kohn A.J. 1964. Type specimens and identity of the described species of Conus. II. The species described by Solander, Chemnitz, Born, and Lightfoot between 1766 and 1786. Journal of the Linnean Society of London, Zoology 45 (304): 151-167. https://doi.org/10.1111/j.1096-3642.1964.tb00492.x

Kohn A.J. 1968. Type specimens and identity of the described species of Conus. IV: the species described by Hwass, Bruguière and Olivi in 1792. Journal of the Linnean Society of London, Zoology 47 (313): 431-503. https://doi.org/10.1111/j.1096-3642.1968.tb00550b.x

Kohn A.J. 1975. Type specimens and identity of the described species of Conus. V. The species described by Salis Marschlins and Röding, 1793-1798. Zoological Journal of the Linnean Society 57: 185-226. https://doi.org/10.1111/j.1096-3642.1975.tb00816.x

Kohn A.J. 1992. A Chronological Taxonomy of Conus, 1758-1840. Smithsonian Institution Press, Washington D.C., USA.

Kohn A.J., Nishi M. \& Pernet B. 1999. Snail spears and scimitars: a character analysis of Conus radular teeth. Journal of Molluscan Studies 65: 461-481. https://doi.org/10.1093/mollus/65.4.461

Küster H.C. 1838. Coneae, oder Conidae, I. Conus, Linne. Systematisches Conchylien-Cabinet von Martini und Chemnitz, neu herausgegeben und vervollständigt von H.C. Küster. Band 4, Abtheilung 2. Raspe, Nürnberg.

Lamarck J.B.P. 1810. Sur la détermination des espèces parmi les animaux sans vertèbres, et particulièrement parmi les Mollusques testacés. Annales du Muséum d'histoire naturelle 15: 1-442. Available from https://www.biodiversitylibrary.org/item/44182\#page/8/mode/1up [accessed 7 Apr. 2020].

Lanfear R., Frandsen P.B., Wright A.M., Senfeld T. \& Calcott B. 2017. PartitionFinder2: new methods for selecting partitioned models of evolution for molecular and morphological phylogenetic analyses. Molecular Biology and Evolution 34 (3): 772-3. https://doi.org/10.1093/molbev/msw260

Lauer J.M. 1993a. Description of a new species and a new subspecies of Conus (Mollusca: Prosobranchia: Conidae) from the Canary Islands. Apex 8 (1/2): 37-50. Available from

http://www.vliz.be/imisdocs/publications/294939.pdf [accessed 29 Mar. 2020].

Lauer J.M. 1993b. Conus cacao Ferrario, 1983, taxonomical and systematic context (Mollusca: Prosobranchia: Conidae). Apex 8(3): 115-127. Available from http://www.vliz.be/imisdocs/publications/294973.pdf [accessed 29 Mar. 2020].

Lightfoot J. 1786. A Catalogue of the Portland Museum, lately the Property of the Duchefs Dowager of Portland, deceased; which will be sold by auction by Mr. Skinner \& Co. London. Available from http://resolver.sub.uni-goettingen.de/purl?PPN603451020 [accessed 29 Mar. 2020]

Link H.F. 1807. Beschreibung der Naturalien-Sammlung der Universität zu Rostock, Mollusken. Part 3: 101-160. Available from http://biology.burke.washington.edu/conus/catalogue/sources/Link,\%20 1807.\%20Besch.\%20Nat.-Samml.\%20Univ.\%20Rostock.\%203e\%20Abth...pdf [accessed 29 Mar. 2020].

Linnaeus C. 1758. Systema Naturae per regna tria naturae, secundum classes ordines, genera, species, cum characteribus, differentiis, synonymis, locis. Tomus I. Editio Decima, Reformata. Laurentii Salvii, Stockholm [Holmiae]. https://doi.org/10.5962/bhl.title.542 
Linnaeus C. 1767. Systema Naturae per regna tria naturae, secundum classes ordines, genera, species, cum characteribus, differentiis, synonymis, locis. Tomus I. Editio Duodecima, Reformata. Laurentii Salvii, Stockholm [Holmiae]. https://doi.org/10.5962/bhl.title.68927

Lister M., Lister S. \& Lister A. 1688. Historice [sive Synopsis methodica] Conchyliorum [quorum omnium picturce, ad vivum delineatee, exhibētur.] Liber IV. qui est de buccinis marinis etiam vermiculj, dentalia, et patella numerantur. ibidem. London. Available from http://resolver.sub.uni-goettingen.de/purl?PPN470145102 [accessed 23 May 2020]

Martini F.H.W. 1773. Neues Systematisches Conchylien-Cabinet, 2. Nürnberg. Available from https://doi.org/10.5962/bhl.title.43760 [accessed 23 May 2020]

Miller M.A., Pfeiffer W. \& Schwartz T. 2010. Creating the CIPRES science gateway for inference of large phylogenetic trees. Proceedings of the Gateway Computing Environments Workshop (GCE): 1-8. 14 Nov. 2010, New Orleans, LA.

Monnier E. \& Limpalaër L. 2010. Conus dorotheae (Gastropoda, Conidae) a new species of cone from the Cape Verde Peninsula in Senegal. Visaya 2 (6): 73-80.

Monnier E., Limpalaër L., Robin A. \& Roux C. 2018. A Taxonomic Iconography of Living Conidae, Vols 1 and 2. ConchBooks, Harxheim.

Monteiro A., Fernandes C. \& Rolán E. 1995. A new species in the genus Conus from Boavista Island, Cape Verde Islands. World Shells 12: 8-13.

Monteiro A., Tenorio M.J. \& Poppe G.T. 2004. A Conchological Iconography; The Family Conidae: the West African and Mediterranean Species of Conus. ConchBooks, Hackenheim.

Monteiro A., Afonso C.M.L. \& Rosa G.D. 2014. Designation of a neotype of Africonus maioensis (Trovao, Rolán \& Felix-Alves, 1990). Xenophora Taxonomy 4: 3.

Neves J.L.B., Lin Z., Imperial J.S., Antunes A., Vasconcelos V., Olivera B. \& Schmidt E.W. 2015. Small molecules in the cone snail arsenal. Organic Letters 17 (20): 4933-4935.

https://doi.org/10.1021/acs.orglett.5b02389

Nguyen L.T., Schmidt H.A., von Haeseler A. \& Minh B.Q. 2015. IQ-TREE: a fast and effective stochastic algorithm for estimating maximum likelihood phylogenies. Molecular Biology and Evolution 32: 268-274. https://doi.org/10.1093/molbev/msu300

Nolf F. \& Verstraeten J. 2008. Conus trencarti (Mollusca: Gastropoda: Conidae): a new cone from Senegal. Neptunea 7 (4): 1-3.

Osca D., Templado J. \& Zardoya R. 2015. Caenogastropod mitogenomics. Molecular Phylogenetics and Evolution 93: 118-128. https://doi.org/10.1016/j.ympev.2015.07.011.

Palumbi S.R., Martin A., Romano S., McMillan W.O., Stice L. \& Grabowski G. 1991. The Simple Fool's Guide to PCR. Ver. 2. University of Hawaii. Honolulu.

Perry G. 1811. Conchology, or The Natural History of Shells; Containing a New Arrangement of the Genera and Species. William Miller, London. https://doi.org/10.5962/bhl.title.64363

Peters H., O'Leary B.C., Hawkins J.P., Carpenter K.E. \& Roberts C.M. 2013. Conus: first comprehensive conservation Red List assessment of a marine gastropod mollusc genus. PLoS ONE 8: e83353.

https://doi.org/10.1371/journal.pone.0083353

Peters H., O’Leary B.C., Hawkins J.P. \& Roberts C.M. 2016. The cone snails of Cabo Verde: marine endemism at a terrestrial scale. Global Ecology and Conservation 7: 201-213.

https://doi.org/10.1016/j.gecco.2016.06.006 
TENORIO M.J. et al., Taxonomic revision of West African cone snails

Petuch E.J. 1975a. A review of the small Mauretanian cone shells with the description of a new genus and a new species (Gastropoda: Conidae). The Veliger 17 (3): 262-263.

Petuch E.J. 1975b. Two new cone species from Senegal, West Africa. The Veliger 18 (2): 180-182.

Petuch E.J. \& Berschauer D.P. 2016. A new species of cone shell (Gastropoda: Conidae) from the Saharan coast of northwestern Africa. The Festivus 48 (2): 93-99.

Petuch E.J. \& Berschauer D.P. 2018. A new Lautoconus species radiation from Gambia, West Africa. The Festivus 50 (3): 164-172.

Phuong M.A., Alfaro M.E., Mahardika G.N., Marwoto R.M., Prabowo R.E., von Rintelen T., Vogt P.W.H., Hendricks J.R. \& Puillandre N. 2019. Lack of signal for the impact of conotoxin gene diversity on speciation rates in cone snails. Systematic Biology 68 (5): 781-796.

https://doi.org/10.1093/sysbio/syz016

Pin M. \& Leung Tack K.D. in Pin M. 1989a. Une nouvelle espèce de gastéropode prosobranche des côtes du Sénégal: Conus belairensis n. sp. Publicações Ocasionais da Sociedade Portuguesa de Malacologia 14: 33-38.

Pin M. \& Leung Tack K.D. in Pin M. 1989b. Étude des canaux anaux des Conidae du Sénégal et leur importance dans la détermination des espèces. Publicações Ocasionais da Sociedade Portuguesa de Malacologia 14: 49-78.

Pin M. \& Leung Tack K.D. 1995. The cones of Senegal. La Conchiglia: International Shell Magazine 277: $1-56$.

Puillandre N., Bouchet P., Duda T.F., Kauferstein S., Kohn A.J., Olivera B.M. \& Meyer C. 2014. Molecular phylogeny and evolution of the cone snails (Gastropoda, Conoidea). Molecular Phylogenetics and Evolution 78: 290-303. https://doi.org/10.1016/j.ympev.2014.05.023

Puillandre N., Duda T.F., Meyer C.P., Olivera B.M. \& Bouchet P. 2015. One, four or 100 genera? A new classification of the cone snails. Journal of Molluscan Studies 81: 1-23.

https://doi.org/10.1093/mollus/eyu055

Quinton L., Servent D., Girard E., Molgó J., Le Caer J.P., Malosse C., Haidar el A., Lecoq A., Gilles N. \& Chamot-Rooke J. 2013. Identification and functional characterization of a novel $\alpha$-conotoxin (EIIA) from Conus ermineus. Analytical and Bioanalytical Chemistry 405 (15): 5341-5351.

https://doi.org/10.1007/s00216-013-6926-x

Raybaudi G. 1992. Preliminary studies for a revision of subgenus Lautoconus (Monterosato,1923) in the Mediterranean sea. Part I: on the true identity of Conus desidiosus A. Adams, 1854. La Conchiglia: International Shell Magazine 23 (263): 10-15.

Reeve L.A. 1843-44. Monograph of the Genus Conus. Conchologia Iconica, I: Figures and Descriptions of the Shells of Molluscs; with Remarks on their Affinities, Synonymy, and Geographical Distribution, 1. Conus. Available from http://biology.burke.washington.edu/conus/catalogue/sources/Reeve, $\% 20$ 1843-9.\%20Conch.\%20Icon..\%20i.\%20Conus..pdf [accessed 29 Mar. 2020].

Reeve L.A. 1848-49. Conus. Emendations applicable to the Monographs of the Conchologia Iconica, and Iconographie des Coquilles Vivantes, Vol. 1. Reeve Brothers, London. Available from http://biology.burke.washington.edu/conus/catalogue/sources/Reeve,\%201848-9.\%20Conch.\%20 Icon..\%20i.\%20Conus.\%20Suppl..pdf [accessed 29 Mar. 2020].

Rivera-Ortiz J.A., Cano H. \& Marí F. 2011. Intraspecies variability and conopeptide profiling of the injected venom of Conus ermineus. Peptides 32 (2):306-316. https://doi.org/10.1016/j.peptides.2010.11.014 
Röckel D. 1978. The rediscovery of Conus siamensis. Hawaiian Shell News 26 (7): 7. Available from https://storage.googleapis.com/conchology-general-images/images/hsn/pdf/1978/7807.pdf [accessed 29 Mar. 2020].

Röckel D. 1982. The continuing uncertainty about Conus siamensis Hwass. Hawaiian Shell News 30 (7): 3. Available from

https://storage.googleapis.com/conchology-general-images/images/hsn/pdf/1982/8207.pdf [accessed 29 Mar. 2020].

Röckel D. 1989. Brown cones from the Mediterranean and West Africa. La Conchiglia: International Shell Magazine 238-241: 21-22.

Röckel D., Rolán E. \& Monteiro A. 1980a. Cone Shells from Cabo Verde Archipelago a difficult puzzle. Feito, Vigo, Spain.

Röckel D., Cosel R. von \& Burnay L.P. 1980b. A new cone from Cape Verde Islands. La Conchiglia: International Shell Magazine 12 (130-131): 10-11.

Röckel D., Korn W. \& Kohn A.J. 1995. Manual of the Living Conidae. Vol. I, Indo-Pacific. Christa Hemmen, Wiesbaden. Available from http://theconecollector.com/RKK/RKK_Download.htm [accessed 29 Mar. 2020].

Röding P.F. 1798. Museum Boltenianum, sive, Catalogus Cimeliorum e tribus regnis naturae quae olim collegerat JoA. Fried Bolten, M.D.p. d., per XL. annus Proto physicus Hamburgensis. Pars Secunda continens conchylia sive testacea univalvia, bivalvia and multivalvia. Johan. Christi. Trapii, Hamburg. https://doi.org/10.5962/bhl.title.10588

Rolán E. 1980. Descripción de tres nuevas especies del género Conus Linné, 1758 (Mollusca: Gastropoda), procedentes del archipiélago de Cabo Verde. Bollettino Malacologico 16 (3-4): 79-94.

Rolán E. 1986. Descripción de tres nuevas especies del género Conus (Gastropoda) del archipiélago de Cabo Verde. Publicações Ocasionais da Sociedade Portuguesa de Malacologia 6: 1-16.

Rolán E. 1990. Descripción de nuevas especies y subespecies del género Conus (Mollusca, Neogastropoda) para el Archipiélago de Cabo Verde. Iberus, Supplement 2: 5-70.

Rolán E. 2005. Malacological Fauna of the Cape Verde Archipelago. ConchBooks, Hackenheim, Germany.

Rolán E. \& Raybaudi Massilia G. 2002. Evaluation of character state polarity of Conus radular tooth characters. Bollettino Malacologico Supplemento 4: 175-194.

Rolán E. \& Röckel D. 2000. The endemic Conus of Angola. Argonauta 13 (2): 5-44.

Rolán E., Röckel D. \& Monteiro A. 1983. New observations on Cape Verde cones, II. La Conchiglia: International Shell Magazine 15 (174-175): 16-17.

Rolán E., Monteiro A. \& Fernandes C. 1998. Cone shells from Cape Verde Islands: new developments, with description of a new species. La Conchiglia: International Shell Magazine 30 (286): 36-44.

Rumphius G.E. 1705. D'Amboinsche Rariteitkamer, behelzende eene bescryvinge van allerhande zoo weeke als harde schaalvisschen, te weeten raare Krabben, Kreeften, en diergelyke Zeedieren, als mede allerhande Hoorntjes en Schulpen, die men in d'Amboinsche Zee vindt: daar beneven zommige Mineraalen, Gesteenten, en soorten van Aarde, die in d'Amboinsche, en zommige omleggende Eilanden gevonden worden. Amsterdam. https://doi.org/10.5962/bhl.title.70350

Schröter J.S. 1803. Neue Conchylienarten und Abänderungen, Anmerkungen, und Berichtigungen nach dem linnéischen System der XII. Ausgabe. Archiv für Zoologie und Zootomie 3 (2): 33-78. 
TENORIO M.J. et al., Taxonomic revision of West African cone snails

Sowerby I G.B. 1823. The Genera of Recent and Fossil Shells, for the use of Students, in Conchology and Geology. London [published between 1821 and 1834]. https://doi.org/10.5962/bhl.title.86281

Sowerby I G.B. 1833. The Conchological Illustrations, or Coloured Figures of all the Hitherto Unfigured Recent Shells. London [published between 1832 and 1841]. https://doi.org/10.5962/bhl.title.11466

Sowerby II G.B. Jr. 1858. Thesaurus Conchyliorum, or Monographs of the Genera of Shells, vol. 3. https://doi.org/10.5962/bhl.title.10596

Tenorio M.J. 2012. Conus ateralbus. The IUCN Red List of Threatened Species 2012: e.T192744A2154590. https://doi.org/10.2305/IUCN.UK.2012-1.RLTS.T192744A2154590.en

Tenorio M.J. \& Afonso C.M.L. 2004. Description of four new species of Conus from the Cape Verde Islands (Gastropoda, Conidae.). Visaya 2: 24-37.

Tenorio M.J., Afonso C.M.L. \& Rolán E. 2008. New endemic species of Conus (Gastropoda, Conidae) from the Islands of São Nicolau, Santo Antão and Sal in the Cape Verde Archipelago. Vita Malacologica 6: $1-10$.

Tenorio M.J., Afonso C.M.L., Cunha R.L. \& Rolán E. 2014. New species of Africonus (Gastropoda, Conidae) from Boa Vista in the Cape Verde Archipelago: molecular and morphological characterization. Xenophora Taxonomy 2: 5-18.

Tenorio M.J., Lorenz F. \& Dominguez M. 2016. New insights into Conus jourdani da Motta, 1984 (Gastropoda, Conidae), an endemic species from Saint Helena Island. Xenophora Taxonomy 11: 32-42.

Tenorio M.J., Afonso C.M.L., Rolán E., Pires S., Vasconcelos P., Abalde S. \& Zardoya R. 2017. DNA sequences disclose a new species of Africonus cone snail from São Vicente (Gastropoda: Conidae). Zoologia Caboverdiana 6 (2): 32-41. Available from

http://www.scvz.org/zoolcv/vol6no2/ZoolCV2017_6_2_Tenorio_etal_Africonus\%20freitasi.pdf [accessed 10 May 2020].

Tenorio M.J., Abalde S. \& Zardoya R. 2018. Identification of new species of Kalloconus and Africonus (Gastropoda, Conidae) from the Cabo Verde Archipelago through mitochondrial genome comparison. The Festivus 50 (2): 73-88.

Trovão H.F.M. 1978. Contribuição para o estudo dos moluscos Gasterópodes da familia Conidae de Angola. Novas espécies de Conus Linné, 1758 de Angola (Mollusca: Gastropoda). Boletim do Centro Português de Actividades Subaquáticas ser. 4, 4: 11-20.

Trovão H.F.M. 1979. Contribuição para o estudo dos Moluscos Gasterópodos da famaia Conidae da África occidental. Amphitrite 1 (1): 3-12.

Trovão H.F.M. \& Rolán E. 1986. Description of a new species for the genus Conus (Gastropoda: Conidae), from the Cape Verde Islands. Publicações Ocasionais da Sociedade Portuguesa de Malacologia 7: 9-15.

Trovão H.F.M., Rolán E. \& Félix-Alves A.V. 1990. A new species of Conus from the Cabo Verde Archipelago, West Africa (Mollusca: Gastropoda: Conidae). Publicações Ocasionais da Sociedade Portuguesa de Malacologia 15: 69-78.

Tucker J.K. \& Tenorio M.J. 2009. Systematic Classification of Recent and Fossil Conoidean Gastropods. ConchBooks, Hackenheim, Germany.

Tucker J.K. \& Tenorio M.J. 2013. Illustrated Catalog of the Living Cone Shells. MdM Publishing, Wellington, Florida, USA.

Uribe J.E, Puillandre N. \& Zardoya R. 2017. Beyond Conus: phylogenetic relationships of Conidae based on complete mitochondrial genomes. Molecular Phylogenetics and Evolution 107: 142-151. https://doi.org/10.1016/j.ympev.2016.10.008 
van Rossum H.M. 1996. A new Conus species from the West African Coast. World Shells 12: 59-61.

van Rossum H.M. 1997. The Conus pulcher Lightfoot, 1786 complex with description of two new forms. World Shells 20: 36-42.

Wagner R.J.L. \& Abbott R.T. 1978. Wagner and Abbott's Standard Catalog of Shells. Third Edition with Supplements. American Malacologists Inc., Conidae section, Greenville, Delaware, USA.

Walls J.G. 1978. Diagnoses of four new cones (Mollusca: Conidae). The Pariah 2: 1-7.

Weinkauff H.C. 1873. Die familie der Coneae oder Conidae. Systematisches Conchylien-Cabinet von Martini und Chemnitz vol. 4 (2): 125-244. Bauer \& Raspe, Nürnberg.

Wilson, J. 1831. Illustrations of Zoology, being Representations of New, Rare or Remarkable Subjects of the Animal Kingdom...with...Descriptive Details. Edinburgh [published between 1826 and 1831].

WoRMS Editorial Board. 2019. World register of marine species. Available from http://www.marinespecies.org [accessed March 2019].

Manuscript received: 16 January 2020

Manuscript accepted: 23 April 2020

Published on: 10 June 2020

Topic editor: Rudy Jocqué

Section editor: Thierry Backeljau

Desk editor: Pepe Fernández

Printed versions of all papers are also deposited in the libraries of the institutes that are members of the EJT consortium: Muséum national d'histoire naturelle, Paris, France; Meise Botanic Garden, Belgium; Royal Museum for Central Africa, Tervuren, Belgium; Royal Belgian Institute of Natural Sciences, Brussels, Belgium; Natural History Museum of Denmark, Copenhagen, Denmark; Naturalis Biodiversity Center, Leiden, the Netherlands; Museo Nacional de Ciencias Naturales-CSIC, Madrid, Spain; Real Jardín Botánico de Madrid CSIC, Spain; Zoological Research Museum Alexander Koenig, Bonn, Germany; National Museum, Prague, Czech Republic. 


\section{Electronic supplementary material}

Supplementary File 1

Maps of sampling sites, and map showing latitudinal variation in species richness of cone snails along the West African coast and Macaronesian islands (adapted from Cunha et al. 2014, by permission of Oxford University Press).

Supplementary File 2

Measurements of the specimens of $K$. canariensis sp. nov. and $K$. pulcher ([Lightfoot, 1786]) included in the morphometric study, plus the lectotype of Conus siamensis Hwass in Bruguière, 1792. Type status is indicated where appropriate.

Supplementary File 3

List of species revised in this monograph. References are listed at the bottom of the Table.

Supplementary File 4

Sequences of 23 pairs of primers specifically designed for the present work.

Supplementary File 5

Maximum likelihood phylogeny of West African cones. The nucleotide sequences of the mitochondrial protein-coding and rRNA genes were concatenated into a single data set. Best-fit partitions and models were inferred (see main text). All nodes in the reconstructed tree had maximal bootstrap support (100\%) unless otherwise stated. The bar indicates substitutions/ site. Genera are indicated by different colors and main clades within Africonus are named with Roman numbers as in Abalde et al. (2017a). 